\title{
RESISTÊNCIA AO CISALHAMENTO DE CONTACTOS SOLO-ROCHA
}

\author{
MILTON ASSIS KANJI
}

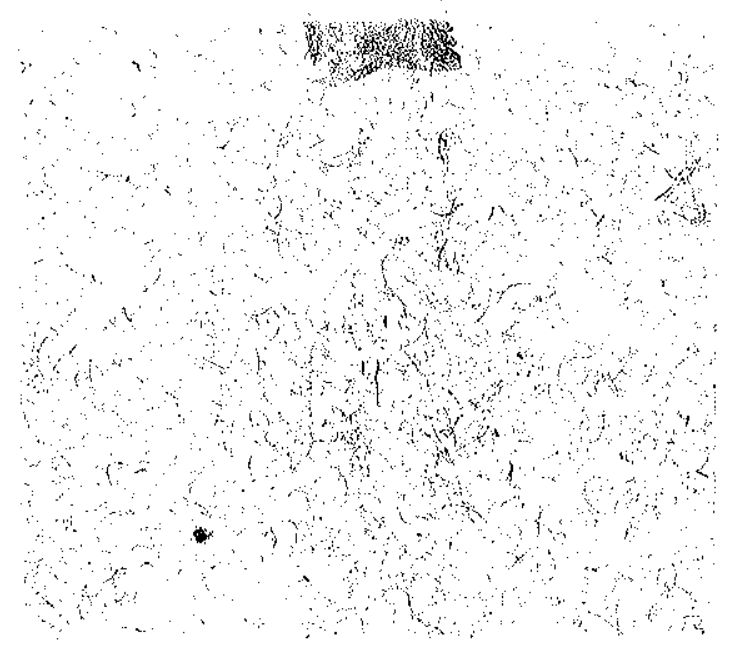

Tese de Doutoramento apresentada

ao Instituto de Geociências da

Universidade de Săo Paulo

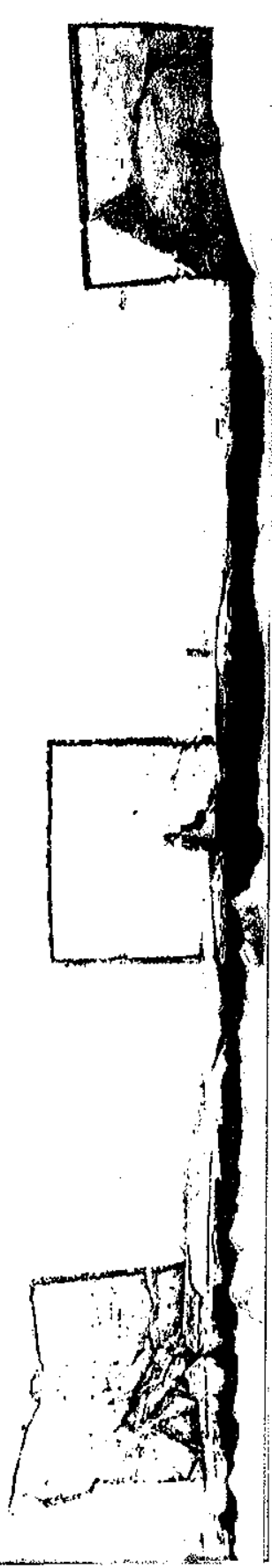




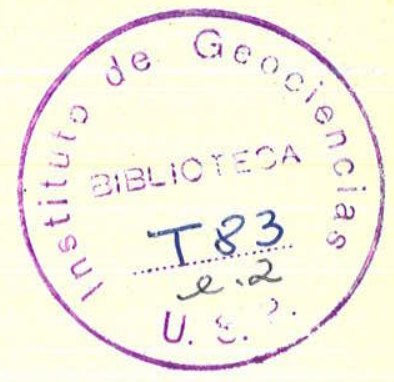

AGRADECIMENTOS

1. INTRODUÇÃO

1.1 - Objetivo da Investigação

1.2 - Aplicabilidade dos Resultados

1.3 - Programação e Condução dos Trabalhos

2. BREVE REVISÃO DA LITERATURA CORRELATA

2.1 - Generalidades

2.2 - Estado de Tensões no Corpo de Prova sob Cisalhamento Direto

2.3 - Resistência ao Cisalhamento de Solos Amolgados

2.4 - Resistência ao Cisalhamento de Planos de Descontinuidade em Rocha

2.5 - Resistência ao Cisalhamento de Contactos Solo-Rocha

3. DESCRIÇÃO DOS MATERIAIS ENSAIADOS

3.1 - Observações Gerais

3.2 - Descrição dos Solos

3.3 - Descrição das Rochas 
4. PROCEDIMENTO DOS ENSAIOS
4.1 - Preparação dos Corpos de Prova
4.2 - Descrição do Equipamento de Cisalhamento Direto
4.3 - Ensaio de Cisalhamento Direto
4.4 - Representação Grāfica

5. APRESENTAÇÃO E DISCUSSÃO 'DOS RESULTADOS
5.1 - Solo " Goose Lake Flour ", e seus Contac tos com o Calcáreo " Bedford "
5.2 - Caolinita da Georgia e seus Contactos - com o Calcāreo " Bedford "
5.3 - Ilita " Marblehead " e seus Contactos - com o Calcáreo " Bedford"
5.4 - Argila Residual de Basalto e seus Contac tos com o Calcāreo " Bedford " e com o Basalto Compacto

5.5 - Silte de Preenchimento de Fraturas em En saio Tipo " Sanduiche "

5.6 - Resistência ao Cisalhamento das Superfícies de Rocha.

5.7 - Ensaios Adicionais para Investigação da Influência do Teor de Umidade, Velocidade de Deformação, e da Confiabilidade dos Resultados

5.8 - Resumo dos Resultados

6. DISCUSSÃO DE OUTROS FATÔRES RELACIONADOS À RESIS TÊNCIA AO CISALHAMENTO 


$$
\begin{aligned}
& 6.1 \text { - Atrito entre Minerais } \\
& 6.2 \text { - Influência da Rugosidade no Atrito de }
\end{aligned}
$$

\section{CONCLUSÕES}

8. SUGESTÕES PARA INVESTIGAÇÕES POSTERIORES 
AGRADECIMENTOS

Desejo inicialmente agradecer ao meu orientador Prof. Dr. Viktor Leinz, do Instituto de Geociências da USP, que contri buiu enormemente para êste trabalho com seus valiosos conselhos, e pelo apoio efetivo dado ao meu projeto de estudar e iniciar esta pesquisa no exterior.

Igualmente, desejo agradecer ao Prof. Dr. Victor F.B. de Mello, da Escola Politēcnica de São Paulo, que me motivou pa ra os campos da Geologia Aplicada à Engenharia e da Mecânica das Rochas e que, desde então, vem constribuindo decisivamente para o meu desenvolvimento atravēs de orientação profissional, de dis cussões claras, e de constante incentivo.

O Prof. Dr. Don U. Deere e o Prof. Dr. Franklin D. Patton, da Universidade de Illinois na época em que desenvolvi parte desta pesquisa, me dedicaram grande parte de seu tempo pa ra contribuir com instrução, assistência e valiosa crîtica cons trutiva. o assunto bāsico deste trabalho foi sugerido pelo Prof. Patton.

Na fase final deste trabalho recebi grande encoraja mento da Profa. Dra. Evelyna B. Souto Silveira, da Promon Enge nharia e da Escola de Engenharia de são Carlos, a quem devo tam bém excelentes sugestões e debates. O Dr. Denys Reeds, também dá Promon Engenharia, cooperou através de diálogos.

vários professores e colegas da Universidade de Illinois deram sua cooperação em ítens importantes: o Prof. Dr. J.L. Eades forneceu as amostras dos solos monominerálicos e rea lizou as análises mineralógicas dos mesmos; o Prof. Dr. R. E. olson forneceu amostras do solo " Goose Lake Flour 'e instruiu - 
sôbre vários aspectos dos ensaios de cisalhamento direto dos so los; o prof. Dr. T.H. Thornburn colocou à disposição o equipamen to de cisalhamento direto utilizado; O Dr. J.H. Coulson forneceu dados de ensaios em andamento à época, para fins de comparação com os obtidos para êste trabalho; O Dr. J. Ward realizou as seç ções delgadas do calcāreo Bedford e me auxiliou no seu estudo mí cropetrográfico; O Sr. A.K. Riggins realizou as anālises granuló metricas dos solos norte-americanos e auxiliou na adaptação do equipamento.

Devo a vārios colegas que pertencem ao Instituto de Pesquisas Tecnológicas, vārias contribuições igualmente importan tes: o Geólogo Guido Guidicini colocou à disposição as facilidades do IPT; O Geólogo Ricardo Silva forneceu amostra de argila residual de basalto de Ilha Solteira; o Dr. Eduardo S. Farjalhah realizou as análises mineralógicas nos solos brasileiros; o Geó logo Riuiti Yoshida colaborou na preparação dos corpos de prova de basalto.

A preparação e caracterização da argila residual foi graciosamente realizada pelo Laboratório Rankine de Solos, por gentileza do Prof. Dr. Araken Silveira, tambēm da Escola Politéc nica de são Paulo.

Os ensaios foram também realizados, em parte, no labo ratōrio de Solos da firma Geotēcnica S.A., a quem agradeço na pessoa de seu diretor, Engo A. H. Teixeira.

A Fundação de Amparo à Pesquisa do Estado de São Paulo forneceu uma viagem aérea aos Estados Unidos, e o Conselho Na cional de Pesquisas uma bolsa de estudos na Universidade de Illinois, a qual tambēm concedeu-me uma bolsa de estudos, antes da vigência da primeira mencionade. Lstas instituições, desse mo do, auxiliaram decisivamente na realização deste trabalho.

Ainda, agradeço à Universidade de são Paulo pelo afas tamento concedido, e à firma Geotécnica S.A., pelo auxilio finan ceiro complementar, bem como à firma Promon Engenharia, pelas fa cilidades concedidas para elaboração de alguns desenhos.

Desejo ainda expressar meus agradecimentos às facili- 
dades e à presteza da firma KANJI - Engenheiros Agrimensores, pa ra a preparação datilográfica dêste texto.

Finalmente, sou muito grato à minha esposa, Maria Antonieta, que continuamente me estimulou e encorajou para êste trabalho. 


\section{INTRODUÇÃO}

\section{1 - Objetivo da Investigação}

Nos estudos referentes à estabilidade de maciços rocho sos, é de capital importância a identificação dos planos de fra queza do maciço rochoso. Êstes planos de fraquesa condicionam a estabilidade do maciço, tanto mais quanto mais adversa a posição dos mesmos com relação às tensões cisalhantes atuantes. De modo geral, os planos de fraqueza consistem de camadas e intercala ções de rocha fraca ou alterada, ou de fraturas e outras descon tinuidades as quais são frequentemente preenchidas por solo.

Quando uma intercalação de solo, argilito, folhelho, etc, apresenta-se em intercalação a camadas de rochas duras, ( ou mes mo de preenchimentos alterados de fraturas e falhas) tem sido prática comum adotar a resistência ao cisalhamento do material de preenchimento como sendo o valor mais baixo da resistência da descontinuidade. Entretanto, conforme foi sugerido por Patton ( 1968 ), existe a hipótese de que a prática acima não seja vá lida, e que a resistência ao cisalhamento do contacto seja inferior à obtida para o solo de preenchimento propriamente dito.

o objetivo desta investigação é o de iniciar o estudo da resistência ao cisalhamento de contactos solo-rocha, e de comparar essa resistência às do solo e da rocha obtidas separadamente.

\section{2 - Aplicação dos Resultados}


As pesquisas sobre um tal assunto são relevantes para a definição da menor resistência ao cisalhamento existente em um maciço rochoso que esteja sendo considerado.

o reconhecimento de zonas de fraqueza é de interêsse em vărias fases dos trabalhos de projeto e construção de obras de engenharia ( Kanji e Brito, 1971 ) desde a programação dos traba lhos de prospecção, projeto e construção propriamente ditos, até a manutenção e observação da obra após a sua entrada em serviço.

Os tipos de obras de engenharia em que se encontram fre quentemente problemas relacionados à resistência ao cisalhamentó de maciços de solo e rocha incluem:

- taludes naturais e escavações artificiais

- taludes de minas a céu aberto

- fundações e ombreiras de barragens

- túneis e outras cavidades subterrâneas

Do ponto de vista estritamente geológico, êste estudo po de consistir em importante subsídio:

- à anālise geomorfológica de taludes e encostas naturais, e

- às análises estruturais envolvendo processos de defor mação das rochas devida à tectônica raza.

A definição mais precisa da resistência ao cisalhamento de planos de fraqueza acarretará um melhor aproveitamento dos vá rios métodos de anālise de estabilidade ( alguns já bastantes dé senvolvidos ) e que incluem necessariamente os parâmetros de ré sistência da feição geológica do tipo em consideração, bem como a obtenção de melhores condições de segurança.

Algumas dessas feições geológicas podem apresentar con tactos bastante planos e lisos, como planos de acamamento regu lares, planos de xistosidade e de clivagem, espelhos de falha, em contacto com solo proveniente de alteração de outras camadas em contacto ou de milonito, etc, . 


$$
1.3
$$

As figuras 1.1 a 1.3 apresentam alguns exemplos de intercalações de solo em maciços rochosos, encontrados em obras civis, em litologia de basaltos e mesmo em gnaisses, demonstrando a amplitude das situações geológicas em que se pode encontrar tais condições.

Outros exemplos de situações geológicas representativas destas condições tem sido abundantemente referidas na literatura, como por exemplo, Patton ( $1966 \mathrm{a}$ e 1966b), Duncan (1969), Piteau ( 1970 ), Deere e Patton ( 1971 ), Tulinov e Molokov ( 1972 ), e Jaeger ( 1972 ), entre outros.

Uma outra aplicação possível dos resultados aqui apresen tados consiste da adoção de valores de resistência ao cisalha mento de contactos entre maciços de terra e de outros materiais de construção, como concreto, em muros de arrimo, zonas de tran sição entre maciços de terra e de concreto, e de estacas de atrí to.

Em vista do exposto, a resistência ao cisalhamento de contactos solo-rocha é de interêsse tanto em engenharia como em geologia, muito em particular para a Mecânica das Rochas e Geolo gia Aplicada. Ademais, auxilia enormemente na compreensão de quais as principais feições devem ser buscadas e prospectadas e quais os fatores que tem significado perante o problema considerado.

\section{3 - Programação e Condução dos Trabalhos}

Para os ensaios dos solos, rochas, e contactos solo-ro cha, foi utilizado um equipamento de ensaio de cisalhamento dire to.

A programação dos ensaios foi feita de modo a fixar o maior número de variáveis, e variar uma a cada vez, sempre que possivel, para cada série de ensaio e para a melhor inter pretação dos mesmos. 


\section{4}

Assim, executaram-se os ensaios da programação principal, segundo resumido na Tabela 1.1. Foram ensaiados 5 tipos de solos com propriedades índices diferentes, numa extensa gama de varia ção e abrangendo um grande número de tipos de solos naturais. Em dois casos, os solos são monominerálicos. Os solos foram ensaiados na condição de amolgados, saturados, e após adensamento, com teores de umidade inicial e final controlados.

Foram também ensaiados dois tipos de rocha, em diferen tes tipos de superfície: uma resultante do próprio corte de serra diamantada, e a outra polida. Em um caso foi ensaiada uma su perfície natural de fratura em contacto com o solo.

Três dos solos foram ensaiados em contacto com um único tipo de rocha e os dois outros solos com outro tipo de rocha. No entanto, um tipo de solo foi ensaiado em vărias condições com am bos os tipos de rocha.

Foram feitos ensaios tipo " sanduíche ", simulando uma fratura preenchida, com um tipo de rocha, mas com dois solos di ferentes, ressaltando-se que a associação de rocha e solos usada ocorre na natureza.

Paralelamente aos ensaios de programação principal, fo ram conduzidos ensaios em solo e em contacto solo-rocha, numa programação adicional, referida na Tabela 1.2 . Nêste programa procurou-se caracterizar a influência de algumas variáveis, inde pendentemente. como a velocidade de deformação do corpo de prova, o teor de umidade, bem como a confiabilidade dos resultados atra vês da duplicação de alguns ensaios.

Ao todo, foram executados 68 ensaios, sendo que alguns ensaios foram realizados ou em vários estágios de tensão normal ou com reversões do deslocamento, mas que foram considerados co mo um único ensaio. As tensões normais empregadas variam de cệ ca de 0,2 a $3,0 \mathrm{~kg} / \mathrm{cm}^{2}$ e as velocidades de deformação utilizadas são consideradas suficientemente baixas para garantir a condição drenada.

Os ensaios foram executados em duas etapas. Na primeira, em 1969, os ensaios foram realizados no Laboratório de Solos e 
1.5

Rochas do Departamento de Engenharia Civil da Universidade de Illinois ( E.E.U.U. ) ; na segunda, nos Laboratórios de Solos da Escola Politécnica da Universidade de são Paulo e da firma Geo tēcnica S.A., em são Paulo. 


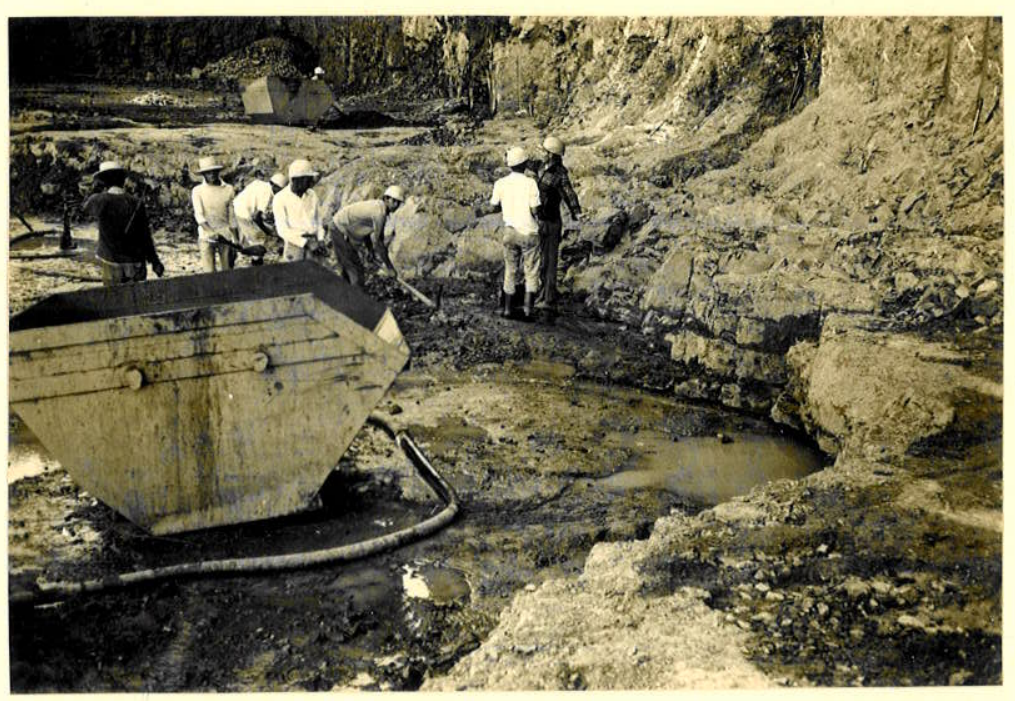

FIG. 1.1 - Escavações das funções de uma barragem, no Rio Grande, S.P., com ocorrência de delgadas camadas alteradas no basalto ( foto gentilmente cedida pelo Prof. A. Bjornberg. 


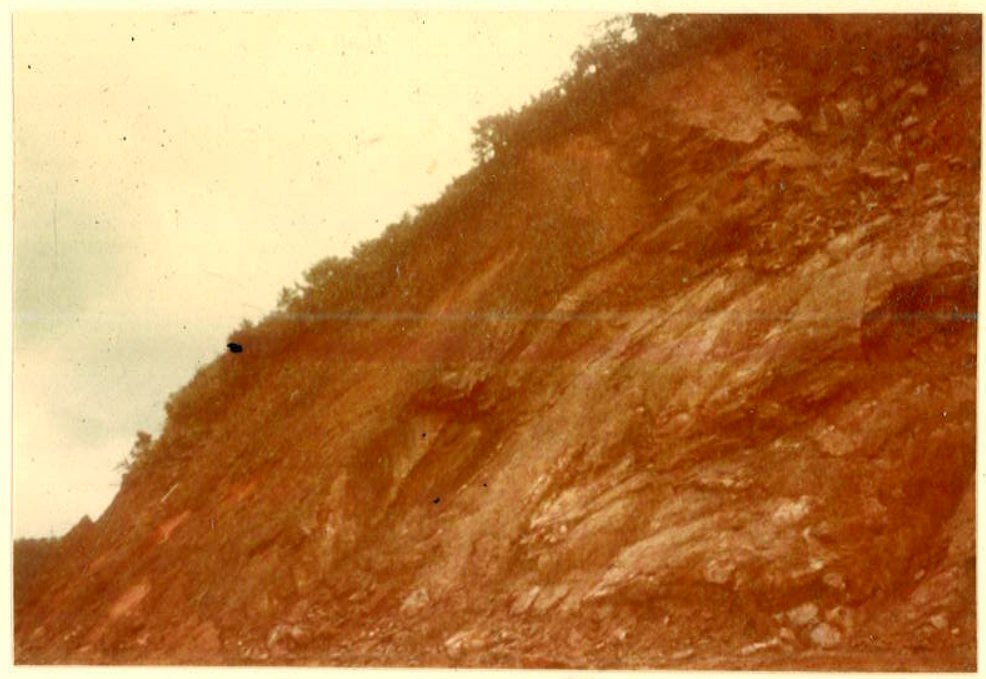

FIG. 1.2 - Escorregamentos provocados por camadas alte radas, em gnaisses, em corte da rodovia Piaçaguera-Gua rujā, S.P. ( foto gentilmente cedida pelo Geólo A. Ribeiro Jr. )

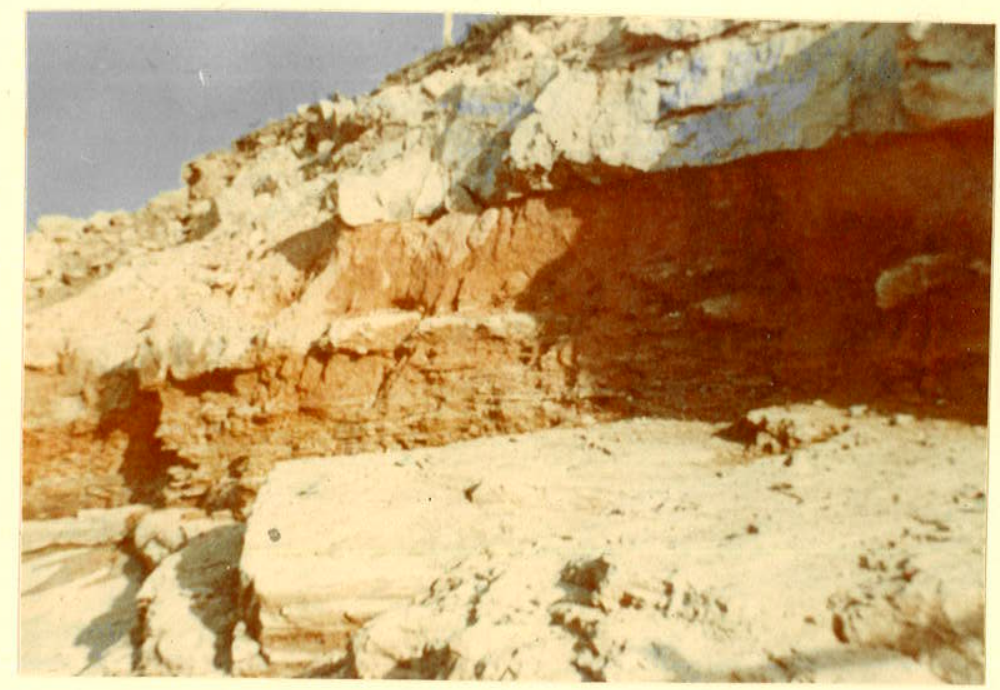

'́lG. 1.3 - Ocorrência de camada alterada em gnaisses nas escavações da barragem de Vargem das Flôres, M.G. ( foto gentilmente cedida pelo Engo J.E.S. Silveira) 


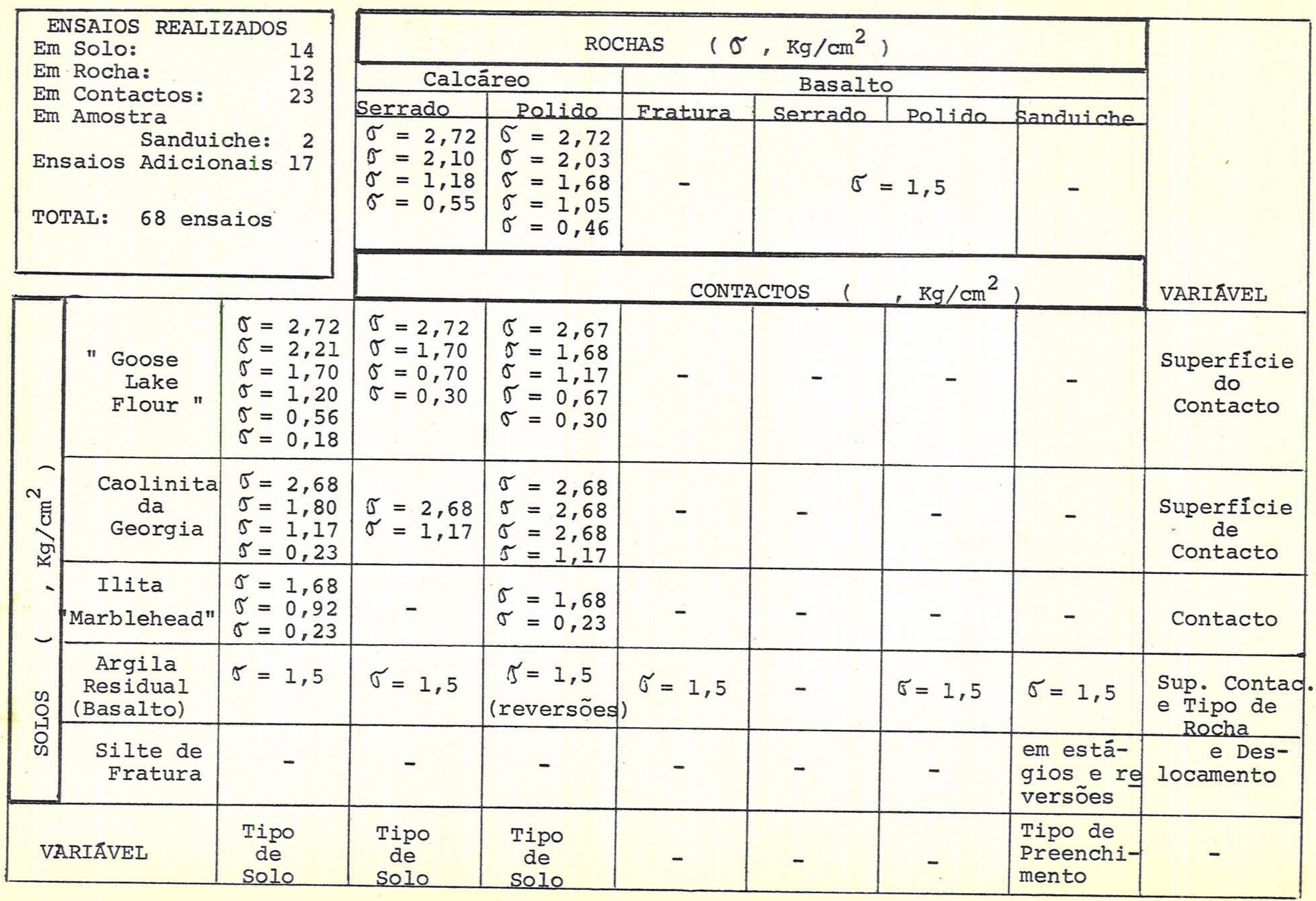

Tabela 1.1 - Ensaios Realizados da Programação Principal 
"GOOSE LAKE FLOUR"

- 5 ensaios à mesma velocidade de deformação

- 3 ensaios em mesmo corpo de prova, mesma tensão normal

- 2 ensaios em mesmo corpo de prova, mesma tensão normal

- 3 ensaios, a diferentes tensões normais, du plicando 3 outros ensaios teor de umidade

desloca/ veloci/ de deformação

desloca/ veloci/ de deformação

corpo de prova

veloci/ de de formação efeito de variação do teor de umidade

obter maiores deforma ções; constância ou = variação de resultados

obter maiores deforma ções; constância ou variação de resultados

investigar se resultados são repetitivos ( confiabilidade)

CONTACTO " GOOSE LAKE FLOUR " - CALCÁREO

- 4 ensaios, mesma tensão normal e mesma superfície da rocha influência da veloci/ de deformação

TOTAL: 17 ensaios

Tabela 1.2 - Ensaios Adicionais à Programação Principal 


\section{1 - Generalidades}

As informações sôbre a resistência ao/cisalhamento de contactos solo-rocha, ou de rocha com outros/materiais de resistência comparável à do solo, são praticamente inexistentes, embo ra se tenha observado que o interêsse e o nümero de informações tem aumentado progressivamente.

Essa escassez de dados é digna de nota, principalmente em comparação ao farto material sôbre a resistência ao cisalha mento dos solos e, tambëm, o volume de publicações e o grande in terêsse sôbre a resistência dos maciços rochosos, demonstrados nos ültimos anos.

Em vista da amplidão da literatura sôbre a resistência dos solos e das rochas, esta revisão teve necessariamente de se restringir aos aspectos mais relevantes relacionados com os estu dos aqui desenvolvidos, como é a resistência mínima ou residual. Assim também, a revisão foi limitada aos ensaios de cisalhamento direto, e à condição de solo amolgado, apenas considerando-se fa tôres diferentes quando julgado de real interêsse para êste estu彑 do.

A inclusão do îtem referente às especulações sôbre o es tado de tensão dos espécimes justifica-se pelo fato de fornecer subsídios valiosos ao julgamento sôbre a representatividade dos cálculos e interpretação dos resultados.

2.2 - Estado de Tensões no Corpo da Prova sob Cisalhamento Direto 
Nos ensaios de cisalhamento direto em solos, rotineira mente executados em Mecânica dos Solos, o estado de tensões sō mente è bem definido no instante que antecede o ensaio e no mo mento da rutura. Para êstes dois casos, Mello e Teixeira ( 1960 ) fornecem esquemas claros da situar:ão inicial, onde a amostra ape nas suporta tensões normais, sendo nulas as tensões cisalhantes, e para a situação na rutura, onde as direções das tensões princí pais estão inclinadas com relação ao plano de rutura, sendo o ân gulo $\Theta$ entre a tensão principal maior e o plano de rutura:

$$
\theta=450+\varnothing / 2
$$

quando se verifica a obliquidade máxima da resultante das ten sões normal e cisalhante.

Durante a passagem de uma para a outra condição, ocorre logo uma rotação gradual dos planos correspondentes às tensões principais.

Sendo indefinidos os estados intermediários, não é possí vel traçar-se trajetōria de tensão, a menos que se adotem prê missas simplificadoras do problema, que restam ainda sem comprovação experimental.

Lambe ( 1969 ) menciona em têrmos gerais como deve ser a trajetória das tensões em função da sequência de eventos no en saio em questão. Durante o carregamento vertical do espécimen, a tensão vertical provocará uma tensão horizontal no solo, em vista de o mesmo estar confinado lateralmente, e como uma função de $\mathrm{K}_{\mathrm{O}}$, o coeficiente de pressão de terra, prōprio para cada materi al. Nêsse carregamento, a trajetōria serā retilínia e, num gráfí co tensão horizontal vs. tensão normal, a inclinação da trajetó ria terá um coeficiente angular $\mathrm{B}$, cuja relação com $\mathrm{K}_{\mathrm{O}}$ é

$$
\mathrm{K}_{\mathrm{O}}=\frac{1-\tan \mathrm{B}}{1+\tan \mathrm{B}}
$$

pressupondo que o incremento de ambas as tensões é constante. 


\section{3}

Após o início da aplicação da tensão cisalhante a trajetória deverā ser mais inclinada que no trecho acima definido, mas que não se pode traçar a não ser nas condições anteriormente mencionadas. Daí resulta que o estado de tensões nas fases inter mediārias do ensaio são apenas aproximadamente conhecidas.

Torna-se lógico que se a definição é boa na rutura, tambēm o será em situação correspondente à resistência residual, uma vez que a obliquidade da resultante permanecerá constante.

Deve-se notar que a trajetória de tensões de Lambe consi dera cada cỉrculo de Mohr definido pela tensão cisalhante máxima, que é algo diferente da utilizada por Casagrande ( 1953 ) que considera o ponto de tangência do círculo com uma reta de inclinação $\varnothing$, admitido para o material. A trajetōria de Lambe parece mais conveniente pelafacilidade em definir seus pontos no círculo de Mohr, embora a de Casagrande tenda a coincidir, no ramo fi nal, com a envoltória de resistência do material. A de lambe corresponde às tensões em um plano de 45 \% e a de Casagrande a um plano de $450+\varnothing / 2$. Tais trajetórias têm sido traçadas em cone xão com ensaios triaxiais.

Um recurso para deduzir o estado de tensões no corpo da prova em um particular instante das fases intermidiārias do en saio de cisalhamento direto foi desenvolvido por Morgenstern e Tchalenko ( 1967 ). Esses investigadores submeteram amostras de caolim pré-adensado a ensaios de cisalhamento direto. Em diferen tes etapas do ensaio as amostras foram endurecidas por técnicas especiais de impregnação, para confecção de secções delgadas e , mediante exame microscópico, estudar a fábrica das micro-estrutu ras desenvolvidas em cada estágio. Reconheceram êles a formação de planos de cisalhamento inclinados com relação ao plano princi pal rutura horizontal conforme citado por Skempton ( 1966 ) e identificado com os planos observados experimentalmente por $W$. Riedel e H. Cloos. Estes planos são as primeiras ruturas a se formar, mas devido à sua posição, interceptados pela caixa, - escorregamento que podem sofrer é muito limitado. Como resultado, com o aumento das tensões cisalhantes, formam-se planos pa 
ralelos à superfície principal de rutura, que coalescem para formar o plano final de rutura. Em todos os casos ensaiados, a inclinação constatada dos planos de Riedel é de aproximadamente $\varnothing / 2$ com o plano final de rutura, podendo existir outro sistema conjugado de planos, cuja inclinação é então de (908 - $\varnothing / 2$ ). Em vista disso, e como a direção da tensão principal corresponde à bissetriz do ângulo agudo formado pelos dois sistemas conjugados de planos de Riedel, Morgenstern e Tchalenko concluem que a inclinação das tensões principais podem ser conhecidas nêsse momento. Em qualquer caso, qualquer que seja o valor de $\varnothing$, as tensões principais, $\sigma_{1}$ e $\sigma_{3}$, estarão inclinadas de aproximada mente 45\% com a horizontal. No entanto, Lajtai ( 1969 ) ensaiou espécimes de gêsso e verificou que a orientação dos planos de Riedel eram mais inclinadas para amostras cúbicas que para amostras prismáticas com o maior eixo na horizontal. Tal fato leva a concluir que a relação encontrada por Morgenstern e Tchalenko é necessariamente afetada pela geometria da amostra.

A descoberta da formação de planos inclinados, como os de Riedel, no ensaio de cisalhamento direto, já havia indireta mente sido feita por Hvorslev ( 1960 ), sem terem sido contudo identificados como tal. Hvorslev utilizou precesso diferente pa ra investigar o efeito do deslocamento na deformação e cisalhạ mento do corpo de prova, introduzindo tiras coloridas, deformā veis juntamente com o solo, fotografando os vārios espécimes a diferentes deslocamentos. Nas fotografias pode-se deduzir claramente a formação desses planos, inclinados com relação à horizon tal, pela deformação das tiras coloridas.

De sitter ( 1956 ) fornece elementos mais detalhados das experiências de Riedel, efetuadas em 1929, para investigar falhas transcorrentes, e com o uso de argila com um certo teor de umida de. Além dos planos citados inclinados de 10\% a 15\% ao plano de cisalhamento, Riedel descreve planos de tração inclinados de aproximadamente 45\%. Como os planos de tração desenvolvem-se ao longo do plano em que atua a tensão principal menor, conclui-se que a inclinação de 45 o deduzida por Morgenstern e Tchalenko pa- 
ra ambas as tensões principais é correta.

A formação de planos de Riedel, alēm de ter sido produzí da em ensaios de laboratório, foi tambēm constatada no campo, em zonas de cisalhamento por Skempton ( 1966 ) e por vários geólo gos estruturalistas.

A principal vantagem em se reconhecer os planos de Riedel consiste em poder estimar no campo o ângulo de atrito do material geológico envolvido, bem como de poder dedurir a direção do movi mento relativo causado pelo cisalhamento. A direção é deduzida pelo fato de que os planos de Riedel fazem um ângulo de valor $\varnothing / 2$ com a direção do cisalhamento, ângulo êsse voltado para a direção do movimento. Em decorrência, como os planos mergulham na direção do movimento, com o desenvolvimento do cisalhamento podem se formar marcas escalonadas nas superficies de falhas,em que os degráus seguem os planos de Riedel e as " escarpas " entre degráus são voltadas contra o sentido do movimento, fato constatado por Coulson ( 1970 ) em cuidadosas experiências de la boratōrio, acompanhadas por êste autor. Essa geometria implica em que o tato mais áspero de superfícies cisalhadas seja no pró prio sentido do movimento, contrariamente ao que se supunha até então.

Com relação à orientação das tensões principais, desco nhece-se era estágios posteriores à formação dos planos de Riedel, até a rutura franca do espécimen, se a mesma orientação permane ce ou se e como se altera.

Outro fator relacionado ao item, e que interessa mais imediatamente aos ensaios de cisalhamento direto é o da distrí buição das tensões no corpo de prova ou ao longo da superfície de rutura. Normalmente, adotam-se as tensões médias ao longo da superficie de rutura como sendo

$$
\begin{aligned}
& \tau_{n}=N / A \quad e \\
& \tau=T / A
\end{aligned}
$$

onde $\quad \sigma_{n}=$ tensão normal

$\mathrm{N}=$ carga vertical 


\section{6}

$A=$ ärea do corpo de prova

$\tau=$ tensão cisalhante

$\mathrm{T}=$ carga horizontal

No caso da tensão cisalhante ser aplicada por esfôrço in clinado ( Ti ), de um ângulo $\propto$, as tensões médias na superfície de rutura serão

$$
\sigma_{n}=\frac{T i \operatorname{sen} \alpha+T i \cos \alpha}{A} \text { e } \tau=\frac{T i \cos }{A}
$$

Isto implica em admitir-se que a distribuição das tensões é uniforme no plano de rutura. Como se suspeita da existência de concentrações de tensão, principalmente nas extremidades da caí xa de cisalhamento direto, tem sido uma constante preocupação sa ber se essas tensões médias fornecem valores representativos da resistência dos materiais, qual a real distribuição das tensões, e se uma vez conhecida essa distribuição podem ser adotados coe ficientes simples para correção dos valôres fornecidos pelo cál culo das tensões médias.

o estado atual de conhecimento ainda não responde inte gralmente a estes pontos, mas um passo significativo já foi dado, conforme se relata a seguir.

Será necessārio distinguir duas situações do ensaiio de cisalhamento direto, conforme usualmente empregados em Mecânica das Rochas, que correspondem à aplicação das tensões cisalhantes tangencialmente ou então inclinadas com relação ao plano de rutú ra. Podem também ser distinguidos ensaios efetuados no laboratório e " in situ ".

Acredita-se que a primeira tentativa feita para investigar a distribuição das tensões no plano de rutura foi feita para modêlos de blocos de ensaio " in situ " por Ruiz et al. ( 1968 ). Os estudos foram feitos por tēcnica de vernizes frágeis e na medida direta das deformações em modêlo bidimensional, e são aplicáveis a meios elásticos, homôgeneos e contínuos. A distribuição das tensões nestas condições e mediante aplicação de fôrça incli nada de 20: mostram a formação de zona de tração na base anterior do bloco, e que as tensões são razoavelmente uniformes no centro 
do bloco mas que próximo às extremidades anterior e posterior so frem alteração de até 100\%. Posteriormente, Ruiz et al ( 1969 ) extendem esse estudo na busca da melhor inclinação do esforço la teral, analizando os casos de 10\%, 20\% e 30\%, e concluindo que a inclinação de 20 e é a melhor delas com relação à distribuição das tensões na base do bloco. Como os próprios autores reconhe cem as premissas adotadas não existem na natureza e sugerem estụ dos pelo método dos Elementos Finitos.

Lorente de Nó ( 1968 ) realizou uma anālise elasto-plástica das tensões e deformações para a condição de ensaios " in situ " com fôrça lateral inclinada ( 30\%? ). Fornece esquemas qualitativos da distribuição das tensões e na superfície de rutura na base do bloco, tanto para o início da plastificação, como para a rutura do material. Seus resultados indicam que no primeiro caso a distribuição das tensões distancia-se mais da condição uniforme que no segundo, onde as tensões são quase uni formes na maior parte da extensão do plano. Em ambos os casos, contudo, aparecem zonas de tração na extremidade anterior do pla no de rutura e, na extremidade posterior, a relação $\tau / \sigma$ é a me nor. Conclui, tambēm, que a adoção de tensões médias calculadas, na rutura, não induz a êrros significativos.

Um estudo recente realizado por Kutter ( 1971), contudo, apresenta interêsse mais imediato pelo fato de ter sido realizado com análises pelo método dos Elementos finitos e simulando um corpo de prova de ensaio em laboratório, e para o caso em que o plano de rutura constitui-se de uma simples descontinuidade e também para o caso de conter delgada camada fraca. Kutter rea lizou análise elāstica apenas, mas contorna a deficiência de não empregar a análise elasto-plástica usando o recurso de des locar a malha do modêlo elástico, para simular o deslocamento apōs plastificação.

A distribuição das tensões principais no modêlo da amostra revelam uma orientação e distribuição semelhante à dos pla nos de Riedel e das deformações observadas por Hvorslev, que ficam desse modo explicadas. Quanto à distribuição das tensões no 


\section{8}

- plano de rutura, Kutter conclui que essa distribuição é muito mais uniforme que a geometria do espécimen poderia seguir, pois é aproximadamente uniforme em ao menos $70 \%$ da porção central do plano de rutura, tanto para a descontinuidade pura como preen chida, sendo que próximo às extremidades as tensões normais cres cem e as cisalhantes decrescem. Dessa forma, a relação $\tau / \tilde{j}$ é menor nas extremidades, sendo de pequena consequência, pois a fratura deveria iniciar-se na porção central do plano. Com rela ção aos deslocamentos, verificou-se tambēm que a sua influência na distribuição das tensões é muito pequena, desde que se limitam a cêrca de $20 \%$ de comprimento total da amostra. Igualmente, a presença de camada fraca praticamente não afeta a distribuição.

Desses resultados, o próprio Kutter conclui que o cálculo de tènsões médias calculadas, como inicialmente mencionado, é um procedimento válido, sem levar a grandes êrros,corroborando com Lorente de Nó.

Sôbre o mecanismo de propagação da rutura, para causar a rutura progressiva, Trollope ( 1967 ) faz interessantes con jecturas, atribuindo o fenômeno à redução de resistência do mate rial com a sua deformação ou à existência de tensões no plano de rutura mais elevadas do que calculado.

Indubitavelmente, o panorama acima deve ser completado com análises pelo método dos Elementos Finitos aplicáveis a amos tras de solo e de amostras compostas solo-rocha, bem como ser ex tendido às vārias situações de ensaios " in situ ".

\section{3 - Resistência ao Cisalhamento de Solos Amolgados}

Conforme apontado, mais acima, as considerações sobre a resistência ao cisalhamento dos solos são restritos à sua obten são por ensaios de cisalhamento direto, apenas se fazendo menção a resultados de ensaios triaxiais quando os mesmos tiverem sido utilizados para revelar fatôres importantes do comportamento dos solos. 
2.9

Acredita-se que os primeiros ensaios de cisalhamento direto, drenados, em amostras delgadas de solos amolgados tenham sido descritos por Terzaghi ( 1925 ); que realizou ensaios de cisalhamento de argila entre camadas de papel de filtro. Posteriormente, Terzaghi ( 1938 ) se refere à existência de resistên cias máximas e residuais, que êle chamou, respectivamente, de resistência " estātica " e " dinâmica ". Notou, ainda, que a existência da resistência " dinâmica ", sendo mais baixa era im portante, pois poderia conduzir ao fenômeno de rutura progressi va no campo.

Ensaios drenados de amostras delgadas, por cisalhamento direto, foram também realizados na Universidade de Harvárd, con forme publicações de Casagrande e Hirschfeld ( 1960 ) e Corso ( 1955 ), onde o solo, com cêrca de 4mm de espessura foi cisalha do entre duas placas circulares de pedra porosa.

Hvorslev ( 1960 ) resume uma boa parte da literatura disponível sobre a resistência de solos amolgados, fazendo referência a seus trabalhos prévios ( 1936 - 1938 ). Hvorslev apresentou a resistência ao cisalhamento dos solos em têrmos de vâ rias componentes, devidas à coesão, atrito, energia, e de fatores reológicos. Outra decorrência de seus estudos foi demons. trar que a coesão não é uma constante de cada solo, mas uma fun ção do teor de umidade do solo. Êle ainda descreveu a ocorrên cia de resistência residual e apontou que para obtê-la, è necessāria grande deformação após a rutura. Grande parte das suas pesquisas foram realizadas com o equipamento de cisalhamento direto, mas tambēm realizou ensaios de cisalhamento por torsão,pa ra obter maiores deslocamentos. Sem dūvida, é em parte devido ao seu trabalho que o ensaio de cisalhamento direto recobrou sua importância, como um meio conveniente e aceito para obter a re sistência ao cisalhamento. Neste tipo de ensaio, Hvorslev algumas vezes realizou a reversão sucessiva do sentido dos desloca mentos, como recurso para simular grandes deslocamentos. A técnica de reversões vem sendo empregada por muitos investigadores nos ültimos anos, inclusive por Skempton ( 1964 ), Kenney (1967), Marsland e Butter ( 1967 ), Sinclair e Brooker ( 1967 ), e vạa - 
ríos outros mencionados por Bishop et al ( 1971 ). Usualmente, os ensaios em reversão fornecem pequenos picos de resistência ao início de cada ciclo de deslocamento, mas o resto da curva ten são vs. deformação representa uma continuação da do ciclo anterior e assim, sucessivamente, alcança-se valôres praticamente constantes após vários ciclos.

Mitchell ( 1955 ) realizou ensaios drenados de cisalha mento direto em amostras finas de solos amolgados, tendo notado a necessidade de prover as placas porosas com dentes de bom relevo para evitar o escorregamento no contacto do solo com a pe dra porosa, o que fornecia valôres mais baixos. Tal fato é im portante, considerando os resultados dêste estudo, uma vez que algum escorregamento entre o solo e pedra porosa ou papel de fil tro seria dificilmente evitável nos ensaios anteriores. Assim,al guns dos resultados publicados podem corresponder à resistência do contacto entre o solo e pedra porosa ou papel de filtro. Os ensaios realizados por Mitchell foram feitos sobre amostras amol gadas e em estágios de tensão normal na mesma amostra; com o au mento do deslocamento acumulado, a resistência sofreu alguma re dução, que Mitchell procurou compensar ensaiando um novo corpo de prova à tensão normal mais alta utilizada.

Após a " Rankine Lecture " de Skempton ( 1964), a impor tância da resistência residual para a estabilidade a longo pra zo de taludes em argilas ficou decisivamente estabelecida. Posteriormente, Skempton e Petley ( 1967 ) extenderam as acue las investigações a argilas duras, prë-adensadas, e demonstraram que o conceito de resistência residual exa tambēm aplicável e válido para as descontinuidades das argilas duras, provando que com deslocamentos muito pequenos a resistência desses planos, fre quentemente apresentando estrias de fricção, já se reduzia ao vâ lor residual.

Deere ( 1967 ) menciona a ocorrência comum de " milonitos " em rochas argilosas, os quais apresentavam apenas a resistência residual, pelo fato de terem sofrido movimento pelo cisalhamento. Tambëm, refere-se a diversos tipos de problemas de es 


\subsection{1}

tabilidade de maciços rochosos com tal feição, principalmente de rochas sedimentares e metamórficas.

Um desses problemas é exemplificado por stimpson e Walton ( 1970 ), com referência à estabilidade de taludes de minas de carvão a cẻu aberto na Inglaterra.

Mais ou menos durante a dëcada de 1960 foram publicadas várias tentativas para correlacionar o ângulo de atrito com al gumas propriedades índices de solos argilosos, principalmente com os limites de consistência ou com indice de plasticidade, in cluindo as publicadas por Kenney ( 1959 ), Bjerrum e Simoms ( 1960 ), Holt ( 1962 ), Skempton ( 1964), Brooker ( 1964 ) , Brooker e Ireland ( 1965 ), Mitchel ( 1965 ), Bjerrum ( 1967 ), e Deere ( 1967 ). Tal correlação, se bem desenvolvida, pode ser um modo muito simples e conveniente para a estimativa do ângulo de atrito atravēs de um ensaio simples, rāpido e barato. As correlações publicadas, mencionadas acima, são comparadas com as obtidas, neste estudo, no item 6 . Menciona-se, ainda, que spears e Taylor ( 1972 ) encontraram uma relação linear em escala monologarítmica entre o ângulo de atrito residual e a proporção das frações arenosa e argilosa.

As investigações de Kenney ( 1967 ) em vârios solos natü rais, solos monominerálicos, e solos de mistura biminerálicos, trouxe à tona a relação existente entre a resistência residual e a composição mineral, e também a salinidade da água intersticial nas montmorilonitas sódica e cálcica. Os seus ensaios foram padronizados para a tensão normal de $1 \mathrm{Kg} / \mathrm{cm}^{2}$, tendo resultado uma grande gama de valôres de resistência residual. Resumidamente, os ensaios de Kenney são os seguintes:

\begin{tabular}{|c|c|c|c|c|}
\hline Minerais ou Solos & Ângulo & de & $\frac{\text { Atrito }}{\varnothing \text { res. }}$ & o \\
\hline $\begin{array}{l}\text { Minerais maciços } \\
\text { ( quartzo, calci } \\
\text { ta, feldspato) }\end{array}$ & & 290 & a & $35 \circ$ \\
\hline Minerais micāceos & & 170 & a & 268 \\
\hline Caolinita & - & & $15 \%$ & \\
\hline Solos Naturais & & 60 & a & 310 \\
\hline
\end{tabular}


Kenney foenece propriedades indices dos materiais ensaia dos, o que se constituiu em valioso material para estudo compara tivo, aqui feito, da correlação dos ângulos de atrito residuais com os limites de consistência. Contudo, Kenney menciona que para solos naturais não hã boa correlação entre Øres. e plasticidą de, fração menor que 2 micra, ou teor de umidade, e menciona que essas correlações eram ainda piores para os solos monominerálicos. Cita, ainda, que ensaios idênticos em amostras amolgadas, com baixo e alto teores de umidade, deram valôres iguais de re sistência e de teor de umidade no estado residual aos de amos tras indeformadas, sob o mesmo nível de tensões normais.

O trabalho mais recente de Bishop et al ( 1971 ) trata de vários aspectos da resistência ao cisalhamento de argila, mas particularmente de resultados de ensaios em equipamento de tor são, desenvolvido no Imperial College, Londres; êsses ensaios fô ram conduzidos até deslocamentos de ordem de $50 \mathrm{~cm}$, e são do tipo drenado, tendo sido utilizadas pequenas velocidades de des locamento, da ordem de até $0,001 \mathrm{~mm} / \mathrm{min}$, apresentando também re sultados de outros investigadores, com velocidade de 0,0002 mm/ min. Um aspecto importante revelado nesse trabalho é a absoluta concordância entre resultados de Øres em ensaios de argilas amolgadas e de planos de rutura naturais em amostras indeforma das do mesmo material. Grande parte do trabalho é dedicado à comparação de resultados de ensaios de mesmos solos por tipos dí ferentes de ensaio, incluindo ensaios triaxiais e de cisalhamento direto em amostras contendo um plano previamente cortado, e com apoio de dados publicados, Nêsse particular, concluem que o ensaio de cisalhamento direto com reversão dos deslocamentos é um bom ensaio para fins práticos, apresentando boa concordância com os ensaios de torsão quando realizados a tensões normais aci ma de aproximadamente $0,7 \mathrm{Kg} / \mathrm{cm}^{2}$. Abaixo dessa tensão os ensaios de torsão fornecem resultados de 10 a $30 \%$ mais baixos. Por êsses motivos, classificam o ensaio de torsão como o melhor para a obtenção do ângulo de atrito residual. Por último, calculam para cada solo ensaiado os indices de friabilidade ( "brittleness 


\subsection{3}

index ") definido por skempton ( 1967 ), ou seja,

$$
I_{B}=(\tau \operatorname{máx}-\tau \text { res }) / \tau \text { māx, }
$$

e concluem que êsse îndice é variável para cada solo em função da tensão normal, menos acentuadamente como o aumento das ten sões, e que as diferenças no mesmo indice para os diversos solos é devida à contribuição de três fatôres, a saber, a dilatância na rutura, a reorientação de partículas adjacentemente ao plano de rutura, e às fôrças de aderência entre partículas.

Em suma, conclue-se que o uso de ensaios de cisalhamento direto em amostras amolgadas é um método razoável e conveniente para determinar a resistência residual dos solos, e que Øres é um parâmetro importante no estudo da resistência ao cisalhamento dos solos, folhelhos ou rochas similares, e preenchimentos argi losos de descontinuidades da rocha. Embora se tenha feito vā rias correlações tentativas entre o ângulo de atrito residual dos solos com suas respectivas propriedades indices, desconhecese se pode ser estabelecida tal correlação com dispersão muito pequena ou se há algum fator adicional a considerar para tor nar a correlação bem representativa, e qual esse fator. Ade mais, alguns dos valôres publicados de Øres podem ter sido in fluenciados parcialmente ou totalmente por escorregamento pelo contacto entre o solo e a pedra porosa ou papel de filtro adja centes. Esses ensaios seriam, então, semelhantes em natureza aos efetuados nêste estudo.

\section{4 - Resistência ao Cisalhamento de Planos de Descontinuidade em Rocha}

Já é amplamente reconhecido o fato de que a resistência ao cisalhamento de maciços rochosos è em primeira análise dependente da presença, orientação e características de resistência de descontinuidades da rocha e de seus planos de fraqueza.Jaeger ( 1959 ) descreve resultados de ensaios triaxiais em testemunhos de rocha contendo superfícies naturais e artificiais de desconti 


\subsection{4}

nuidade, inclinadas a diversos ângulos com relação à tensão axial para investigar sua correspondente variação nos resultados; nesse estudo, encontrou que a resistência ao cisalhamento das su perfícies de rocha seguia a lei linear

$$
\mathrm{S}=\mathrm{C}+\mathrm{N} \tan \varnothing
$$

onde $N$ è a carga normal, c é a coesão e $\varnothing$ é o ângulo de atrito das superfícies.

Donath ( 1961 ) tambēm realizou ensaios triaxiais, em ar dósias, e observou uma importante ređução na resistência ao cisa lhamento quando os planos de clivagem estavam a certas orienta ções críticas com relação à tensão axial. Ensaios adicionais so bre, a influência da presença de planos de fraqueza na rocha fo ram publicados por Lane e Heck ( 1964), Brown ( 1968), Brown e Trollope ( 1970 ), e vários outros.

A influência da mineralogia e da saturação na resistên cia ao cisalhamento foi investigada por Horn e Deere ( 1962 ) que realizaram ensaios de atrito em superfícies de minerais, abran gendo vários tipos de minerais comuns. Com relação à saturação, revelaram que a ăgua funciona como lubrificante em superfícies de minerais micáceos, e como antilubrificante nos minerais maci ços, quando aumenta seus respectivos coeficientes de atrito.

Posteriormente, or mecanismos de rutura por cisalhamento das superfícies rochosas tornaram-se melhor conhecidos, Particularmente, a função dos deslocamentos na resistência foi reconheci da, bem como da natureza da superfície. Ripley e Lee ( 1961) descrevem as diferenças obsevadas na resistência de planos lisos e rugosos. Levando em conta o ângulo $i$ de inclinação das rugosidades, resultou uma expressão matemática que, simplificada por Withers ( 1964 ), adquire a forma

$$
S=N \tan (\varnothing+i)
$$

Por outro lado, Maurer ( 1966 ) realizou uma série de ensaios de cisalhamento direto a altas tensões em superfícies de fraturas naturais, encontrando que a sua resistência era melhor expressa pela expressão não linear

$$
\mathrm{S}=\mathrm{a} \mathrm{\textrm {N } ^ { \mathrm { k } }}
$$




\subsection{5}

e que a variou de 4 a 60 e $k$ de 0,4 a 0,8 para os vários tipos de rocha ensaiadas Deduz-se que ambas as expressões são representativas, dependendo fundamentalmente do nivel e da gama de variação das tensões normais empregadas.

A dependência da resistência ao deslocamento e a varieda de de curvas que se pode obter podem ser constatadas nos muitos trabalhos existentes, abrangendo vários tipos de rocha, como por exemplo, Krsmanović e Langof ( 1964 ); Krsmanovic̄, Tufo e Lan gof ( 1965 ); Krsmanovic̄ e Popovic ( 1966 ), e Krsmanovī̄ $(1967)$.

Usando do recurso de ensaiar corpos de prova de gêsso, e variando a geometria das superfícies de contacto, Patton (1966a) estabeleceu as idéias básicas para interpretar a resistência ao cisalhamento de superfícies com diferentes geometrias. Patton ( 1966b) também indicou como seus estudos poderiam ser aplica dos à interpretação de resultados de ensaios de cisalhamento di reto em fraturas reais de rocha e " in situ ". Complementando seu estudo, Patton realizou investigações de campo, da estabilidade de taludes rochosos naturais. Medindo os ângulos de inclina ção de planos potenciais de ruturas ou onde a rutura jā havia ocorrido, e aplicando os resultados de seus ensaios, concluiu que as irregularidades de primeira ordem ( ou ondulações ) des ses planos de rutura governavam a estabilidade dos taludes.

Trabalhando concomitante e independentemente, Goldstein

et al ( 1966 ) desenvolveram expressão matemática semelhante à de Patton para a resistência de superfícies irregulares. Esses estudos indicaram a importância potencial da resistência residual em vários tipos de situações envolvendo a estabilidade de maci ços rochosos.

Com relação à anisotropia da resistência e à queda da re sistência em função do deslocamento, Uff e Nash ( 1967 ) usaram - equipamento de cisalhamento direto para ensaiar superfícies de acamamamento de folhelhos dobrados, em varias direções divergentes ao rumo do mergulho dos flancos das dobras, concluindo que segundo o rumo do mergulho a resistência era a menor devido 
ao movimento de origem tectônica já ocorrido.

No tocante ao estudo da rutura de meios fissurados, Trollope e Brown ( 1966 ) realizaram ensaios de cisalhamento direto para ilustrar a influência da posição de um ou mais siste mas de fraturas na amostra. Posteriormente, Brown e Trollope ( 1970 ) ensaiam geometrias mais complexas, inclusive por ensaios triaxiais. Rocha ( 1970 ) desenvolveu avançada teoria para a ru tura de meios fissurados, contando com dois sistemas de fraturas e podendo-se atribuir diferentes coeficientes de atrito a ca da uma delas, permitindo calcular a rutura nas direções deseją das.

Paralelamente às investigações acima citadas, outros autores principalmente devotados às investigações de fundações de barragens e interessados em ensaiar amostras maiores e mais representativas, desenvolveram vārios equipamentos e métodos de ensaio de cisalhamento direto " in situ ". Tais ensaios restrin giram-se praticamente a determinar a resistência de planos de fraqueza ou de descontinuidade da rocha. Ensaios " in situ " desse tipo foram descritos por Niederhoff ( 1939 ) em folhelho ; Thorfinnson ( 1954 ) em folhelho com camadas de bentonita; Schultz ( 1957 ) em lignito, Grishim e Evdokimov ( 1961 ) em rocha e concreto; Serafim e Lopes ( 1961 ) em granitos; Salas e Uriel ( 1964 ) em lignito; Mello ( 1966 ) em quartzito; Ruiz e Carnargo ( 1966 ) em grande bloco de basalto com camada de arenito; Boughton e Haee (1967) em quartzito com fraturas preenchidas; Ruiz et al ( 1968 ) em basaltos e fraturas em basaltos; e vários outros. Deve ser destacada a publicação por Nieble e Guidicini ( 1972 ) de inümeros dados obtidos em vários tipos e vārias condições de rochas, mas principalmente em basaltos, e também a análise crítica das interpretações de ensaios " in situ" por Mello ( 1966 ).

No entanto, a gama de variação das condições da geometria das superfícies naturais de fraturas ( ou rugosidade) é relativamente grande e irregular, impedindo estimativas razoāveis da resistência nessas fraturas, o que levou vārios investigadores a 


\section{17}

pesquisas mais aprofundadas da influência da rugosidade,

como Kanji ( 1970 ), Robertson ( 1970 ), Coulson ( 1970 ), Rengers (1970), e Barton ( 1971 ).

Coulson ( 1970 ) investiga a resistência de fraturas por equipamento de cisalhamento direto, de 10 tipos diferentes de ro chas e com vārias grandezas de rugosidade média, obtidas por di ferentes processos de preparação, e inclui tambēm ensaios em superficies naturais de fratura. Coulson conclui que o coeficiente de atrito inicial ( início do escorregamento) aumenta com o aumento da rugosidade, mas que o coeficiente de atrito residual é dependente do grau e tipo de destruição da superfície. Esse dano da superfície pode compreender um dos três processos se guintes: polimento, milonitização, e formação de crôsta. o dano da superfície, por sua vez, depende da rugosidade, da saturação, da tensão normal, e dureza da rocha. Esta ültima correlacionase muito bem com a resistência à compressão simples, o que possi bilitou a Coulson encontrar boa correlação entre Øres e resis tência à compressão simples.

Essa última correlação foi tambēm constatada por Barton ( 1971 ), o qual entretanto usou Ømāx. em lugar de Øres.

Barton realizou ensaios em modêlos de fraturas, regis trando cuidadosamente nos ensaios as deformações verticãis e horizontais, cuja relação nos dá dn , a dilatancia da fratura,que expressa fisicamente o efeito da inclinação das rugosidades. Encontrou uma relação entre a resistência máxima da fratura, a dilatância e o atrito fundamental da rocha ( $\left.\phi_{b}\right)$, em superfícies lisas da seguinte forma:

$$
\tau / \tau_{n}=\tan (2 d n+\phi b)
$$

Por outro lado, notou que a dilatância é uma função da resistência à compressão $\left(\sigma_{C}\right)$ e da tensão normal, dando a expressão

$$
d_{n}=10 \log \left(\sigma_{c} / \tau_{n}\right)
$$

Considerando $\varnothing \mathrm{b}$ igual a 30\%, que è um valor aproximado, comum à maioria das rochas, e condensando ambas as equações acima, temse:

$$
\tilde{\sigma} / \sigma_{n}=\tan \left[20 \log \left(\sigma_{c} / \sigma_{n}\right)+300\right]
$$




\section{18}

relação que nos permite estimar com boa aproximação a resistên cia máxima ảo cisalhamento daquele tipo de fraturas.

Em conclusão, vārias têm sido as tentaitivas para correla cionar ou definir com precisão aceitavel os parâmetros de resistência de descontinuidade ou planos de fraqueza, pois as mesmas constituem-se no principal condicionante da estabilidade de maci ços rochosos. No caso de planos rugosos e de tração, a relação de Barton é muito útil. Entretanto, é universalmente reconhecido - fato de que as descontinuidades que já sofreram movimento, por causas tectônicas, podem ter sua resistência diminuida até a re sistência residual, caso em que é de interêsse conhecer-se os meios para obtê-la. A êsse respeito o trabalho de coulson é relevante, bem como o de Kutter e Figueroa ( 1971 ) que investiga ram com sucesso a possibilidade de realizar ensaio rotativo de testemunho cilindrico de sondagem e fragmento de rocha, com car regamento puntual, com perfeita coincidência com outros métodos convencionais de ensaio. Faltam, contudo, elementos que permi tam racionalizar e estimar a resistência residual das várias rochas; por isso tem havido recentemente interêsse em desenvol ver propriedades indices correlacionáveis ao Øres e que permita sua estimativa rápida. Tambēm, embora jā existam importantes estudos sobre a influência da rugosidade e da espessura dó preen chimento das fraturas, esses fatores carecem ainda de melhor de finição, requerendo estudos posteriores.

\section{5 - Resistência ao Cisalhamento de Contactos Solo-Rocha}

Muito pouca informação existe sôbre a resistência de con tactos solo-rocha e muito menos sobre a sua resistência residual. A maior parte dos investigadores que enfrentaram problemas envol vendo tal condição, descrevem resistências máximas ( pico) e en saiaram a rocha e o solo separadamente. Em outros casos, foram ensaiadas, quer no laboratório, quer no campo, amostras compos - 
tas constituidas de rocha dura incluindo intercalações de folhe tho ou de solo. No entanto, na maioria dos casos, ou a superfície de contacto era muito irregular, o que resultará em obter-se a resistência intrínseca do material mais fraco, ou o solo não foi ensaiado sozinho. Dessa forma, torna-se difícil extrair dados conclusivos da bibliografia, bem como compará-los com os re sultados dêste estudo. Serão citados abaixo os dados mais repre sentativos encontrados.

Krsmanović e Popovic ( 1966 ) descrevem ensaios "in situ " de $5 \mathrm{~m}^{2}$ de área feitos em calcāreo com fraturas preenchi das com argila, tendo-se plicado tensões normais de até $25 \mathrm{Kg} / \mathrm{cm}^{2}$ Os ensaios abrangeram fraturas com diferentes espessuras de preenchimento. Para o caso de fraturas com preenchimento da ordem de 10 a $20 \mathrm{~mm}$ obtiveram valores de фmáx variando de 12\% a 250 com os caos de espessura maior fornecendo valôres mais baixos. Para o caso de fraturas com menos de lomm de espessura, obtive ram Ømáx de 230 para superfícies lisas e de 310 para super fícies rugosas, caracterizando assim que a rugosidade aumenta o coeficiente de atrito. Lamentavelmente, não fornecem resultados do solo propriamente dito, para comparação.

Goldstein et al ( 1966 ) apresentaram resultados de en saios de cisalhamento direto em superfícies saturadas. Obtive ram valôres do ângulo de atrito de 140, para mármore sobre mármore, de 280 para mármore sobre arenito, e de 10 \% para uma intercalação de argila de folhelho. Suspeita-se que os resultados correspondem à condição residual, embora nada seja indicado. Não pôde ser estabelecido se a intercalação é em mármore ou entre mármore e arenito. Tão pouco pôde-se deduzir se o ângulo de 10 o corresponde à resistência do contacto ou se representa ensaio do solo propriamente dito.

Uriel ( 1968 ) relata resultados de ensaios de cisalhamento direto " in situ " em fraturas irregulares preenchidas por argila. Aparentemente, os valôres fornecidos correspondem a re sistências máximas. Em um dos ensaios êle obteve um valor de $\varnothing$ de 27,89, enquanto em ensaios de laboratório no solo de preen 
chimento obteve $14,5 \%$ e, em outro caso, obteve $31,8 \%$ no ensaio " in situ " e 30,9\% no laboratōrio. Não se sabe se tais resultados refletem puramente condições de ensaio e nem se a rutura se deu no contacto ou no solo.

Leussink e Kirchembauer ( 1967 ) descreveram resulta dos de ensaios triaxiais em material de preenchimento de fratu ras, nos quais tentam alcançar resistências residuais através do uso de rótulas no equipamento para permitir maior deformação. Infelizmente, não ensaiaram amostras contendo o contacto solorocha.

Boughton e Hale ( 1967 ) dão um passo a frente, nos ensaios para investigação das fundações de barragem de Cethana, em arco, em quartzitos com fôlhas e fraturas preenchidas. Realizaram ensaios de cisalhamento direto " in situ " das fraturas preenchidas e obtiveram valôres do coeficiente de atrito de 0,4 a 0,5 para fraturas lisas e de 0,6 para fraturas rugosas. Tais resultados, comparados ao resultado de 0,6 dos ensaios tria xiais do preenchimento propriamente dito, parece constituir-se em excelente indicação de que a resistência do contacto é menor, e que quando o contacto é muito irregular a rutura ocorre pelo solo apenas.

Kazimierez ( 1970 ) constatou que, em ensaios de cisa lhamento direto no laboratório em amostras indeformadas colhidas do mesmo local onde foram executados ensaios " in situ " de contactos xisto-argilito, quando a superfície de contacto é lisa, resulta um valor de $\varnothing$ aproximadamente 5 o inferior ao de su perfície rugosa, mas a grandeza das irregularidades da superfície não são mencionadas. Constata ainda, comparando dois en saios com diferentes espessuras de preenchimento em fraturas de superfícies lisas, que o que apresentava maior espessura era mais fraco. Considera que para superfícies rugosas a espessura do preenchimento é irrelevante, pois sempre refletirá a resistência do material de preenchimento.

A êsse mesmo respeito, Rengers ( 1970 ) prognostica que se a espessura do preenchimento for grande a resistência cor- 
2. 21

responderá à do solo, e que se as irregularidades da superfície da rocha se tocarem apōs algum deslocamento então o coeficiente de atrito da fratura será correspondente ao da descontinuidade rochosa.

Locher ( 1970 ) ensaiou no laboratório fraturas de rocha com e sem uma camada de preenchimento de $3 \mathrm{~mm}$, formando amos tra tipo sanduiche, tendo encontrado uma redução da ordem de 3 : a 69 no ângulo de atrito, no caso de existência do preenchimento, do qual não fornece valôres, prejudicando a comparação.

Essa comparação, contudo, pode ser feita em um dos vā rios ensaios " in situ " de cisalhamento direto realizados por Giuseppe ( 1970 ), de onde se obtem os seguintes valôres:

$\begin{array}{ccc}\text { Contacto } & \underline{\phi m a ̄ x} & \underline{\phi r e s .} \\ \text { Calcāreo - Calcāreo } & 40 \% & 40 \% \\ \text { Folhelho - Folhelho } & 32 \% & 30 \% \\ \text { Folhelho - Calcáreo } & 22 \% & 21 \%\end{array}$

de onde se conclui que a resistência ao longo do contacto entre rochas dura e mole é a menor que de qualquer dos materiais envol vidos, o que tambēm é declarado por Giuseppe. Essa mesma conclusão, deve-se ressaltar, foi obtida das investigações realiza das numa primeira fase por êste autor (Kanji, 1969 e 1970 ), e divulgada por Patton e Deere ( 1970 ).

O recente estudo de Tulinov e Molokov ( 1971 ) procura caracterizar os fatôres intervenientes na resistência de fraturas preenchidas, tendo procedido a inümeros ensaios sob variadas si tuações, incluindo preenchimentos argilosos e granulares. Esses autores demonstram que no caso de preenchimento argiloso a menor resistência é apresentada pelo contacto, e que no caso de preen chimentos granulares o $\varnothing$ é máximo quando o diämetro dos grãos é de 20 a $100 \mathrm{~mm}$. Tulinov e Molokov tambēm constatam que descontinuidades de gênese tectônica que sofreram movimentos apresentam resistência muito menor. Em ensaios sob tensões nor mais crescente, observaram a extrusão da argila de preenchimento e o concomitante aumento progressivo de $\varnothing$ nos casos em que a espessura era pequena, que atribuiram ao aumento também progres 


\section{22}

sivo dos pontos de contacto rocha-rocha.

Assim, pode-se ver que há alguns ensaios realizados,tanto " in situ " como no laboratório, e que envolvem a presença de contacto solo-rocha, porēm muito poucos permitem a compara ção da resistência ao cisalhamento dos contactos com os dos so los respectivos. Esses poucos resultados, contudo, permitem con cluir que, em certas condições, o contacto é o plano de menor re sistência, Nenhum trabalho, no entanto, define ou investiga as variações de resistência com as da rugosidade em têrmos efetivos. Assim também a influência da espessura do preenchimento é avalia da qualitativamente apenas. A leitura crítica dos trabalhos aci ma também leva a concluir que muito maior número de resultados seriam ūteis e utilizāveis para importantes estudos de correla ção, caso tivessem sido melhor descritas as suas condições, ou, em alguns casos, caso fossem realizados uns poucos e simples en saios adicionais.

Finalmente, não pode deixar de ser mencionada a existência de vários trabalhos com resultados de ensaios de contatos entre solo e concreto ou outros materiais de construção, que são semelhantes em gênero aos aqui apresentados. A aplicação de tais ensaios é voltada principalmente para fundações e obras de terra. Os vários trabalhos do gênero contam da revisão fei ta por Schultze e Horn ( 1967 ), devendo-se ainda adicionar o de Chuang e Reese ( 1969 ). 
3. DESCRIÇÃO DOS MATERIAIS ENSAIADOS

\section{1 - Observações Gerais}

Três dos solos utilizados, o solo " Goose Lake Flour ", a caolinita da Geórgia e a ilita " Marblehead ", e um dos tipos de rocha, o calcāreo " Bedford " são de procedência norte-americana.

Os materiais brasileiros consistiram de uma argila resi dual de basalto obtida em Ilha Solteira, um silte de preenchimen to de fratura obtido de testemunhas de uma sondagem de recuperação integral em Ãgua Vermelha, e amostras de basalto compacto de Ågua Vermelha.

\section{2 - Descrição dos Solos Utilizados}

" Goose Lake Flour " - Este é um solo poliminerálico,constituido de uma mistura de partículas de areia, silte e argi la, processada comercialmente. O interêsse em incluir-se êste solo entre os empregados na pesquisa consiste em que o mesmo é considerado um solo padrão em investigações de Mecânica dos Sọ los na Universidade de Illinois, existindo jā consideravel quan tidade de dados publicados sobre o mesmo ( Brooker, 1964;Brooker e Ireland, 1965 ) permitindo comparações posteriores entre os pa râmetros obtidos em diferentes ensaios. Constituiu-se, portanto, numa espécie de padrão de aferição dos resultados dos ensaios - 
dêste solo realizados para esta pesquisa. Apesar de apresentar o menor Indice de plasticidade e a menor porcentagem da fração me nor que 2 micra, possui nümero de atividade um pouco maior que o da caolinita, provavelmente devido à presença de minerais de ar gila mais ativos que a caolinita, de acôrdo com anālise de difrá ção de Raios-X. A sua atividade é algo maior que o da caolinita, provarrelmente devido à presença de ilita e outros minerais mais ativos que a caolinita.

Caolinita da Geórgia - Trata-se de solo constituido de caolim praticamente puro, conforme determinado por difração de Raios-X . Em vista de o solo natural, recebido na forma de tor rão, apresentar algumas partículas arenosas de quartzo, o mesmo foi peneirado via úmida, tendo-se usado(para a caracterização e ensaios) apenas a fração passando na peneira nūmero 200 .

Ilita "Marblehead" - Êste solo é constituido por cêrca de 95\% de ilita, constituindo-se em material de excepcio nal pureza, conforme referido por Gaudette, Eades e Grim ( 1965 ). Representa o solo de maior indice de plasticidade e atividade, comparativamente aos precedentes.

Argila Residual de Basalto - êste solo'é caracterizado pela presença preponderante de montmorilonite, embora contenha também outros minerais de argila, quartzo e minerais primários do basalto ( augita e labradorita) e limonita. A identifica ção dos minerais foi feira por análise de difração de Raios-X, Análise Térmica Diferencial, e exame microscópico.

Comparativamente aos demais solos utilizados, este é o que possui o mais alto limite de liquidez; embora o Indice de plasticidade seja aproximadamente igual ao ca ilita, a atividade da argila residual é maior que a da ilita, provavelmente em vir tude da sua composição montmorilonítica.

Silte de Preenchimento de Fratura - Devido à restrita 
quantidade disponível deste material, cêrca de $10 \mathrm{~cm}^{3}$, são se pôde proceder aos ensaios de caracterização do mesmo. Registrase, contudo, que é constituído predominantemente de silte pouco argiloso. O exame petrográfico, a análise por difração de Raios-X, e a Análise Térmica Diferencial revelam que è constituí do principalmente de labradorita e pequena quantidade ( 5 a 10\%) de augita, com traços de quartzo e zeólitas. Os grãos são angulo sos. A argila presente é do tipo montmorilonita. O material apre sentava na fratura fissuramento secundário indicando jā ter so frido cisalhamento.

As propriedades básicas da caracterização dos solos acima são apresentados na Tabela 3.1 e na Figura 3.1 .

A Tabela 3.1 apresenta os limites de Atterberg nas 3 primeiras colunas, e a seguir a fração menor que 2 micra e $\circ$ nú mero de atividade ( relação entre o indice de plasticidade e a fração menor que 2 micra). O resto da tabela apresenta a composição mineralógica dos solos, em têrmos semi-quantitativos em alguns casos, decorrente do próprio processo de análise mineraló gica.

A figura 3.1 representa as curvas de distribuição granulométrica dos solos, com excessão do silte ( devido à muito pou ca quantidade possivel de obter fratura, como anteriormente mencionado). Pode-se notar que a Caolinita e Ilita são praticamente desprovidas de grãos arenosos.

Os métodos dos ensaios de caracterização acima, serão re feridos no îtem 4.

\section{3 - Descrição das Rochas Utilizadas}

\section{Calcáreo Bedford}

o calcáreo da Formação Salem, do Mississipiano de Indiana ( E.E.U.U.) é comumente conhecido como calcáreo " Bedford ", 
pois na localidade homônima existem grandes pedreiras que explo ram êste calcáreo. O mesmo calcáreo ocorre em outras localidades circunvizinhas, como por exemplo Bloomington, Indiana, de onde proveio a amostra estudada. Para mais fácil identificação conser va-se a denominação calcáreo " Bedford ", de uso mais comum.

o calcāreo em questão é um biocalcarenito, formado por partículas quase que exclusivamente de restos de invertebrados, principalmente crinóides, foraminiferos e braquiópodos, com al guns oolitos. O tamanho dos fragmentos varia da ordem de $0,2 \mathrm{~mm}$ a $2,0 \mathrm{~mm}$, com média de $0,5 \mathrm{~mm}$, aproximadamente. A cimentação é feita por calcita.

Uma fotomocrografia dessa rocha é mostrada na Figura 3.2, em ampliação de 9,8 vêzes.

A fim de caracterizar a geometria das superficies rochosas ensaiadas, obtidas através de corte de serra diamantada, e por polimento, foram obtidos perfís das mesmas por meio de um ru gosímetro. A Figura 3.3 apresenta perfís da superfície polida e a Figura 3.4, da superfície serrada ( para fins de comparação, foram tambēm obtidos perfís de rugosidade de superfícies de aço e de madeira lixada, apresentados nas Figuras 3.6 e 3.7 ). № ta-se que paralelamente ao alinhamento das partículas bioclāsticas a regularidade da superfície é maior que no sentido perpendi cular. A micro-rugosidade, em ambos os perfís é da ordem máxima de 1 micron, com algumas depressões que atingem até cêrca de 5 ou e micra e que devem ser causadas pelo arrancamento de diminutos grãos de rocha, ou pelo risco da própria partícula do pó ( 6 micra ). Visualmente, no entanto, a superfície com polimento final apresenta-se brilhante, sem se poder distinguir tais depressões a ôlho nu. No caso da superfície serrada, a mesma já apresenta ondulações, com um comprimento de onda da ordem de $1 \mathrm{~mm}$. a $2 \mathrm{~mm}$., visíveis a ôlho nu, causadas provavelmente pela trepidação da serra ou do mecanismo de avanço da amostra.

\section{Basalto Compacto}

A amostra empregada de basalto compacto foi obtida do 


\section{5}

local em estudos do futuro Aproveitamento Hidrelētrico de Água Vermelha, nas Cachoeiras dos Indios de Ågua Vermelha e da Fumaça, no Rio Grande, a cêrca de $60 \mathrm{~km}$ de Fernandópolis ( SP ).

Pertence aos horizontes superiores do derrame aflorante no leito do rio, localmente designado de " L " .

Os derrames basalticos de Ãgua Vermelha pertencem aos ex tensos derrames mesozóicos da Bacia sedimentar do Paraná-Uruguaí.

o basalto da amostra é de côr prêta, holocristalino, de granulação fina a média, textura ofitica, e constitui-se basicamente de augita ( piroxênio) e labradorita (feldspato).

A geometria resultante da serragem e do polimento desta rocha pode ser apreciada na Figura 3.5, notando-se que a superfície polida do basalto tem micro-rugosidade semelhante à do calcá reo, mas sem grandes depressões, o que é interpretado como sendo devido à boa ligação entre os cristais minerais e à maior dureza da rocha.

Os perfis de rugosidade foram obtidos com o equipamento " Talysurf 4 " ( The Rank Organisation), da Fundação Armando Alvares Penteado, comumente utilizado em Mecânica. 


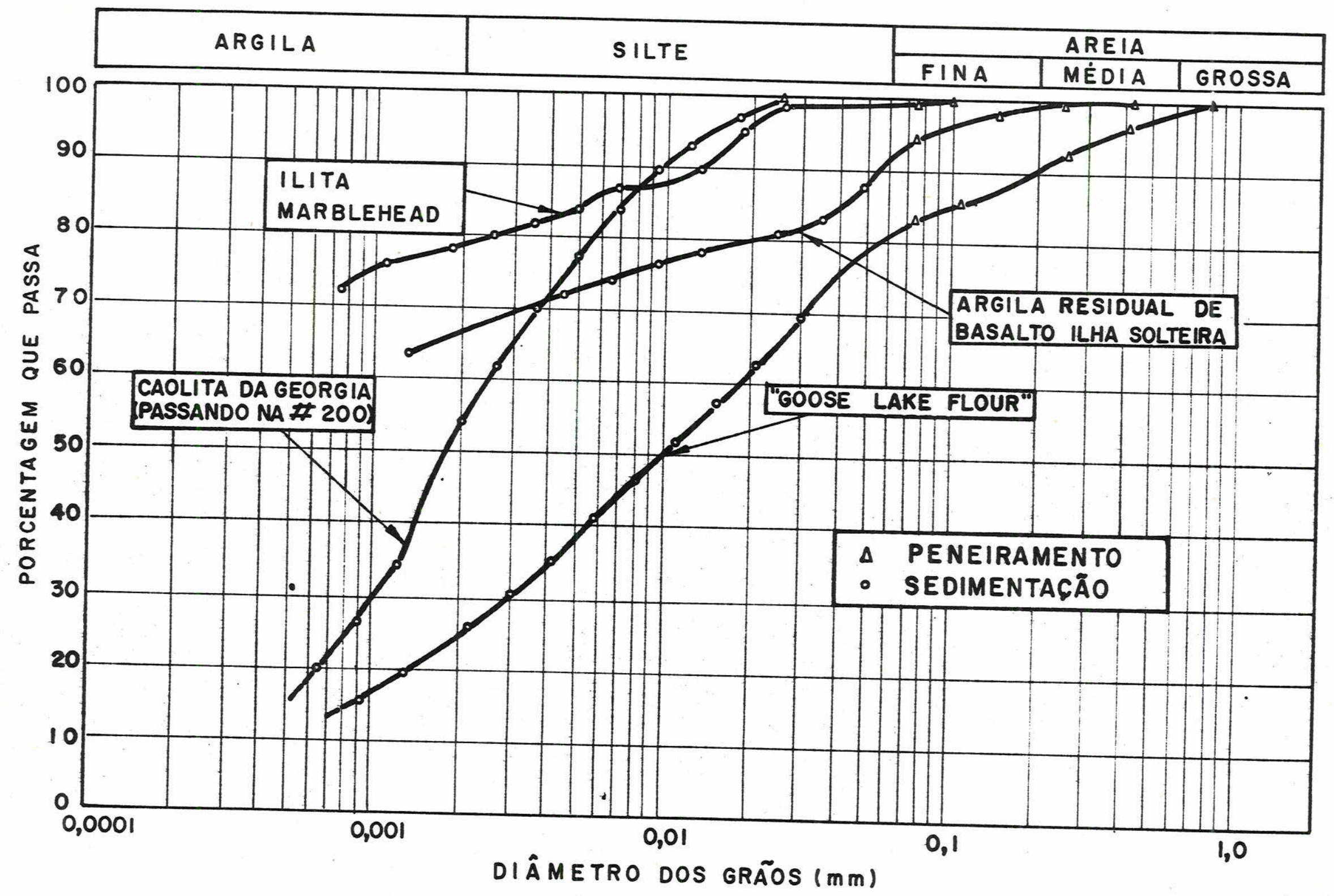

FIG. 3.I- CURVAS GRANULOMÉTRICAS DOS SOLOS UTILIZADOS 


\begin{tabular}{|c|c|c|c|c|c|c|c|c|c|c|c|c|c|c|c|c|}
\hline \multirow[b]{2}{*}{$\begin{array}{c}\text { TIPO } \\
\text { DE } \\
\text { SOLO }\end{array}$} & \multicolumn{5}{|c|}{ PROPR. INDICES } & \multicolumn{11}{|c|}{ MINERAIOGIA (\%) } \\
\hline & 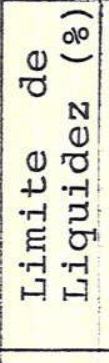 & 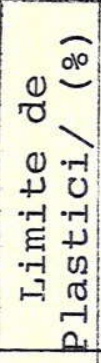 & 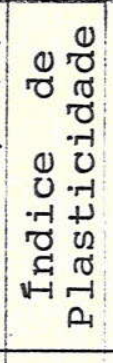 & 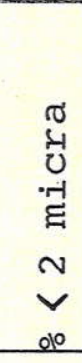 & 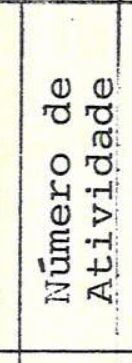 & $\begin{array}{l}0 \\
N \\
+4 \\
4 \\
0 \\
2 \\
2\end{array}$ & $\begin{array}{c}\sigma \\
+ \\
-1 \\
. \\
.-1 \\
-1 \\
0 \\
0 \\
0\end{array}$ & $\begin{array}{l}\underset{\pi}{+} \\
\stackrel{-1}{H} \\
H\end{array}$ & 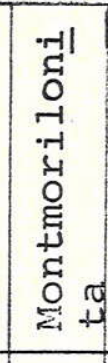 & $\begin{array}{ll} & \\
0 & n \\
\pi & \pi \\
0 & 0 \\
\pi & x \\
0 \\
0 \\
0 \\
0\end{array}$ & $\begin{array}{c}\sigma \\
+1 \\
-11 \\
4 \\
0 \\
-1 \\
0\end{array}$ & $\begin{array}{l}\pi \\
+ \\
-1 \\
-1 \\
0 \\
0 \\
0 \\
0 \\
0 \\
0 \\
0 \\
10\end{array}$ & 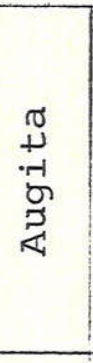 & 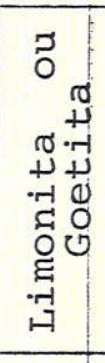 & $\begin{array}{l}02 \\
0 \\
+1 \\
-1 \\
-11 \\
0 \\
0 \\
N\end{array}$ & FONTE \\
\hline $\begin{array}{r}\text { "Goose Lake } \\
\text { Flour " }\end{array}$ & 30 & 18 & 12 & 25 & 0,48 & 25 & 30 & 10 & - & 20 & 15 & - & - & - & - & J. I. Eades \\
\hline $\begin{array}{l}\text { Caolinita } \\
\text { da Georgia }\end{array}$ & 48 & 26 & 22 & 54 & $0,4]$ & - & 99 & - & - & $\sim 1$ & - & - & - & - & - & J. I. Eades \\
\hline $\begin{array}{c}\text { Ilita } \\
\text { "Marblehead" }\end{array}$ & 104 & 27 & 77 & 78 & 0,99 & - & - & 95 & - & $\sim 5$ & - & - & - & - & - & $\begin{array}{l}\text { Gaudete, Eades } \\
\text { e Grim (1965) }\end{array}$ \\
\hline $\begin{array}{l}\text { Argila Residual } \\
\text { de I. Solteira }\end{array}$ & 112 & 38 & 74 & 66 & 1,12 & 5 & 10? & $5 ?$ & $>60$ & - & - & tr. & tr. & $\sim 5$ & - & $\begin{array}{c}\text { J.E.Farjallah } \\
\text { ( IPT ) }\end{array}$ \\
\hline $\begin{array}{l}\text { Silte de } \\
\text { Fratura }\end{array}$ & - & - & - & - & $-t$ & tr. & - & - & - & - & - & $>60$ & 10 & - & tr. & $\begin{array}{c}\text { J.E.Farjallah } \\
\text { (IPT) }\end{array}$ \\
\hline
\end{tabular}

Tabela 3.1 Propriedades Indices e Mineralogia dos Solos Ulilizados 


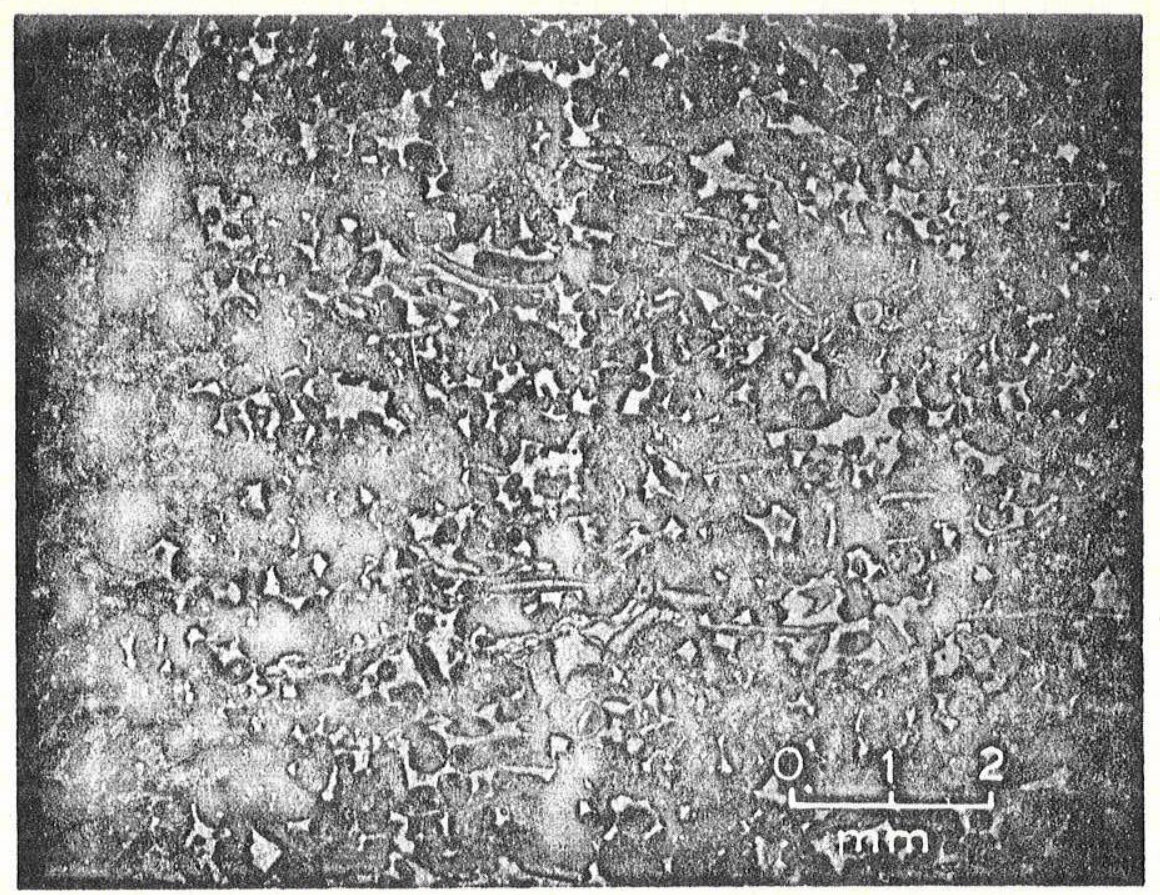

Figura 3.2 - FOTOMICROGRAFIA DE SECÇÃO DELGA DA DO CALCĂREO BEDFORD. 
a)

A. 3 r.

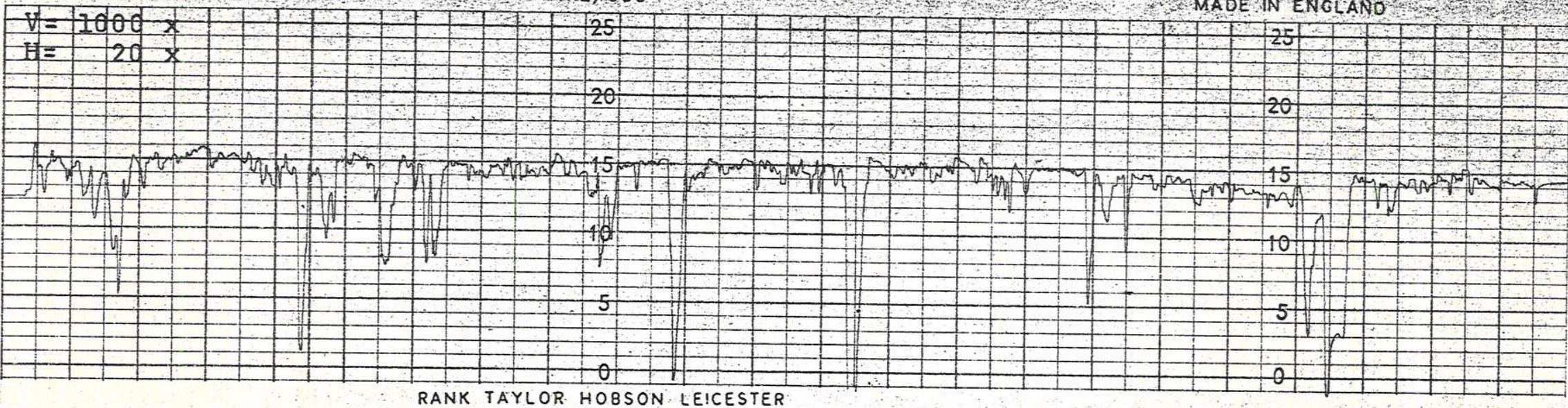

RANK TAYLOR HOBSON LE!CESTER

\section{$112 / 338$}

b)

$112 / 338$ MADE IN ENGLAND

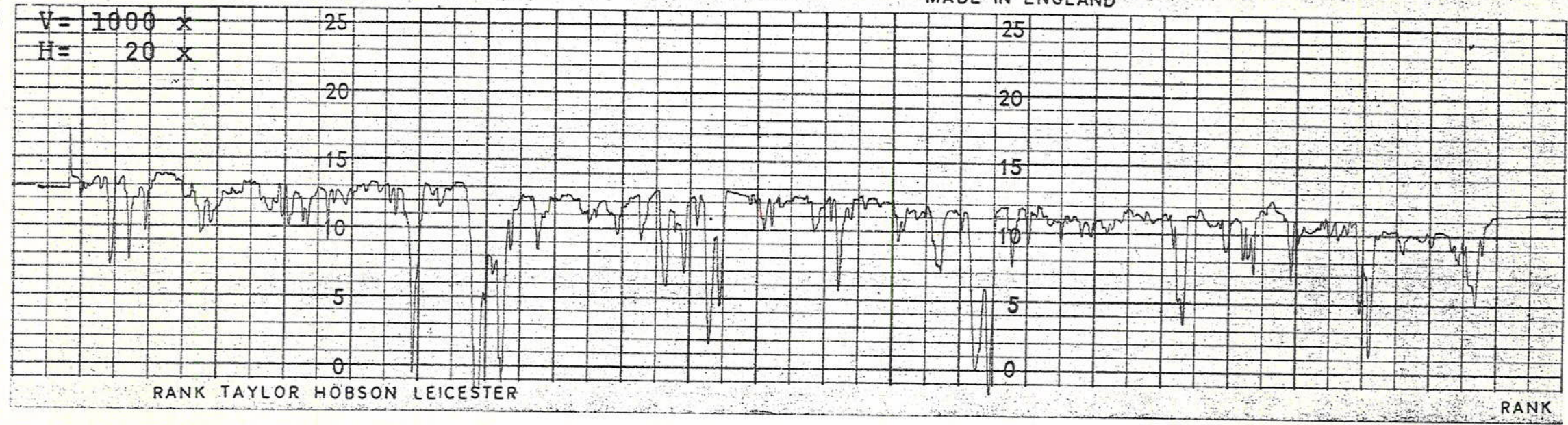

Fig. 3.3.- Perfis da superfície do caĺcáreo (polido): (a) paralelo e (b) perpendicular à lineação. 
a)

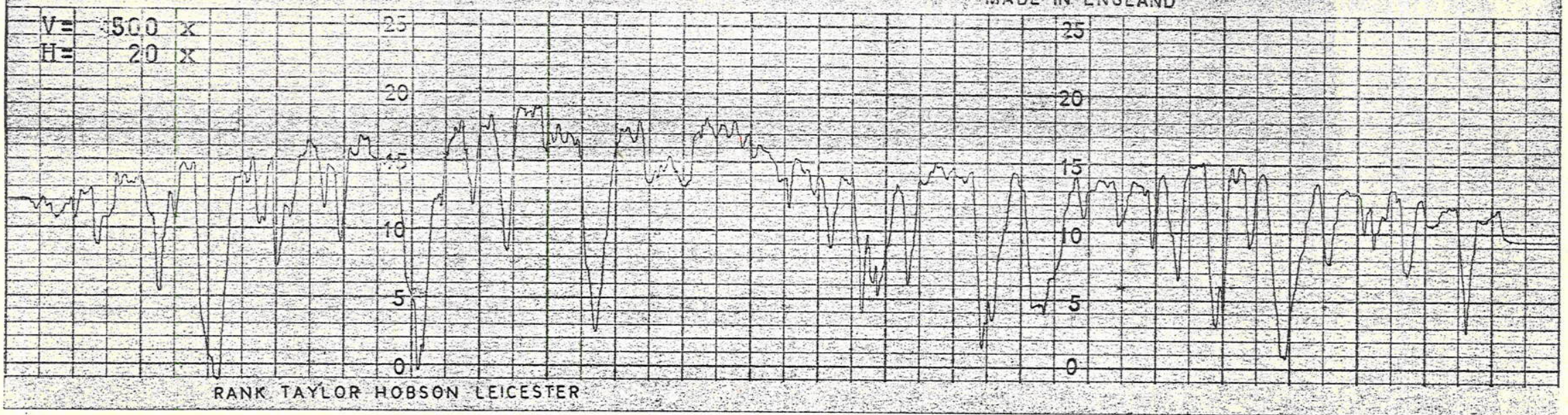

RANK TAYLOR HOBSON LEICESTER

$112 / 338$

MADE IN ENGEAND

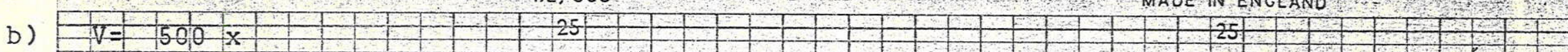
$\mathrm{I}=20 \mathrm{x}$ - 20 -

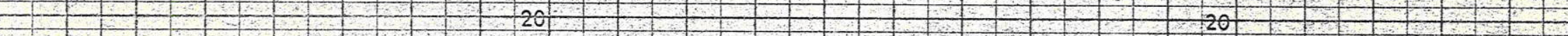

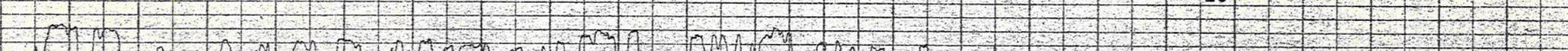

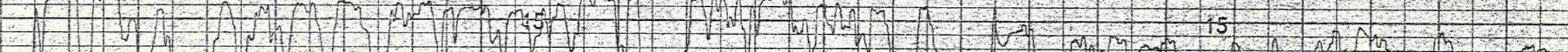

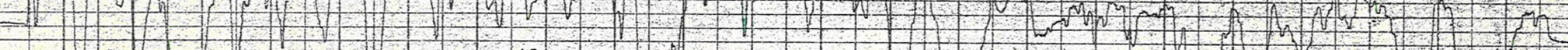

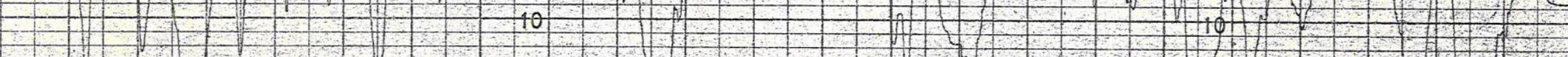

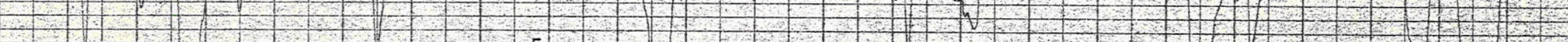

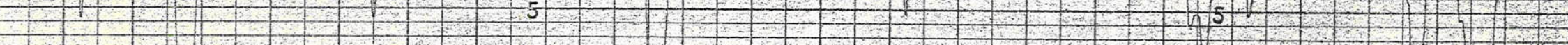

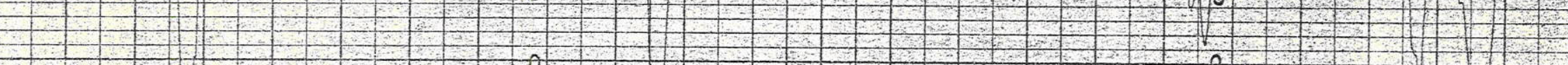

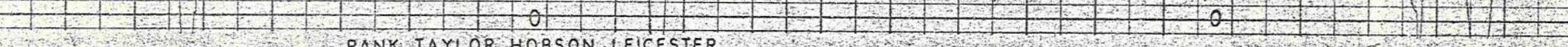
RANK TAYLOR HOBSON TEICESTER

Fig.3.4.- Perfís da superfície do calcáreo (corte de serra), em duas direções normais entre si 
a)

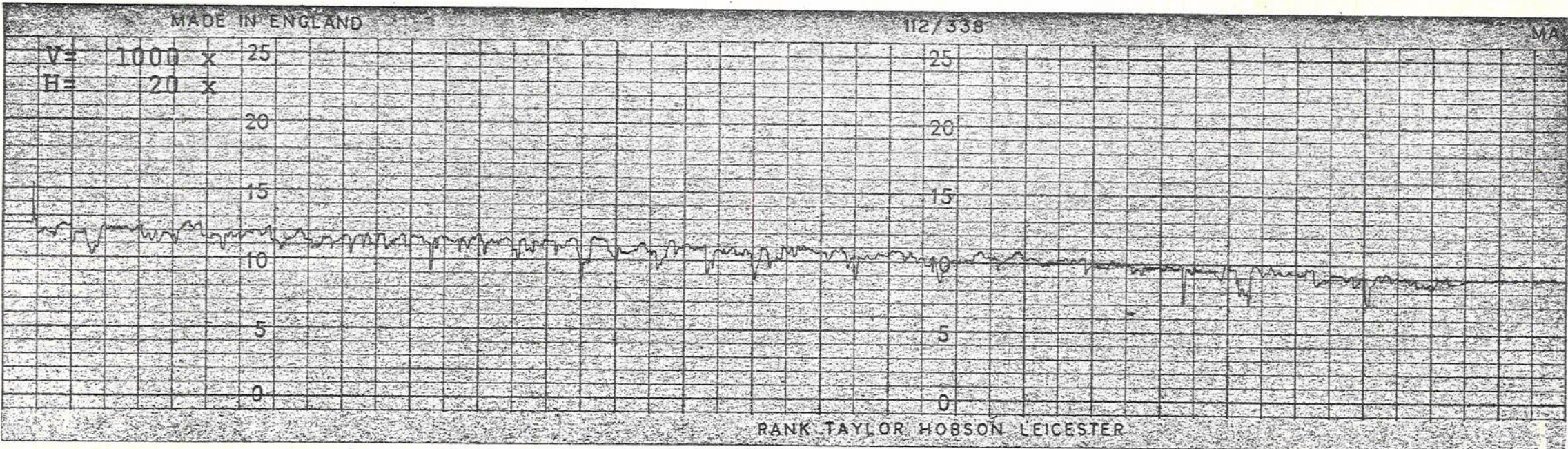

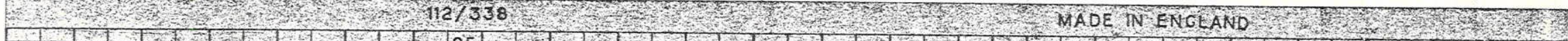

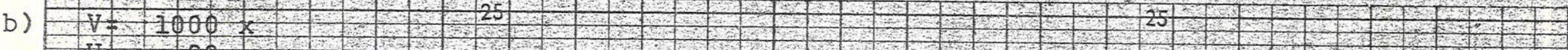

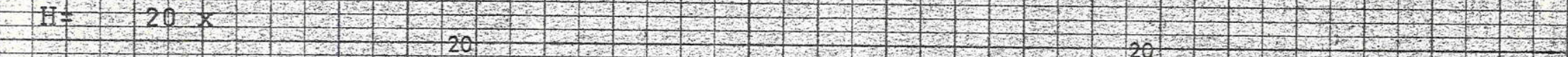

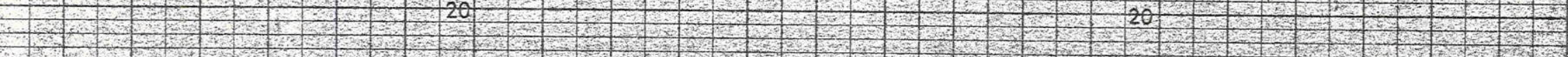

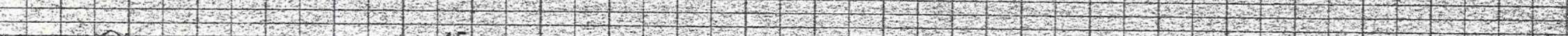

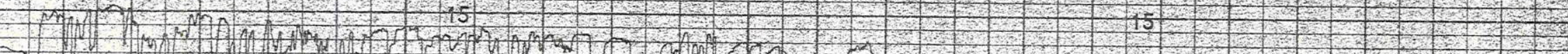

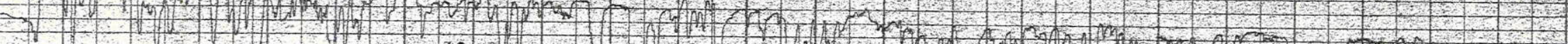

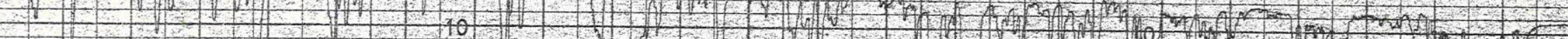

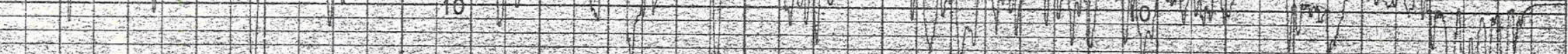

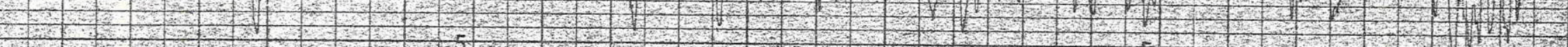

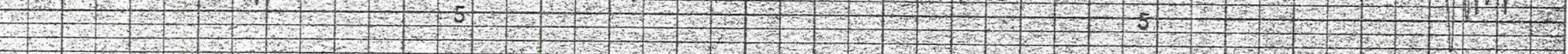

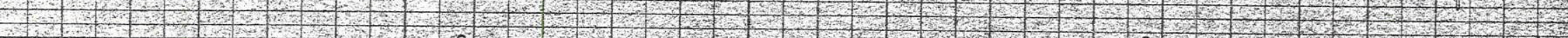

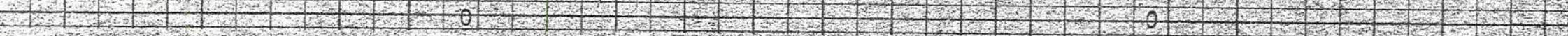
K.

Fig.3.5.- Perfis da superfície do basalto: (a) polido e (b) corte de serra, perpendicular às estrias. 


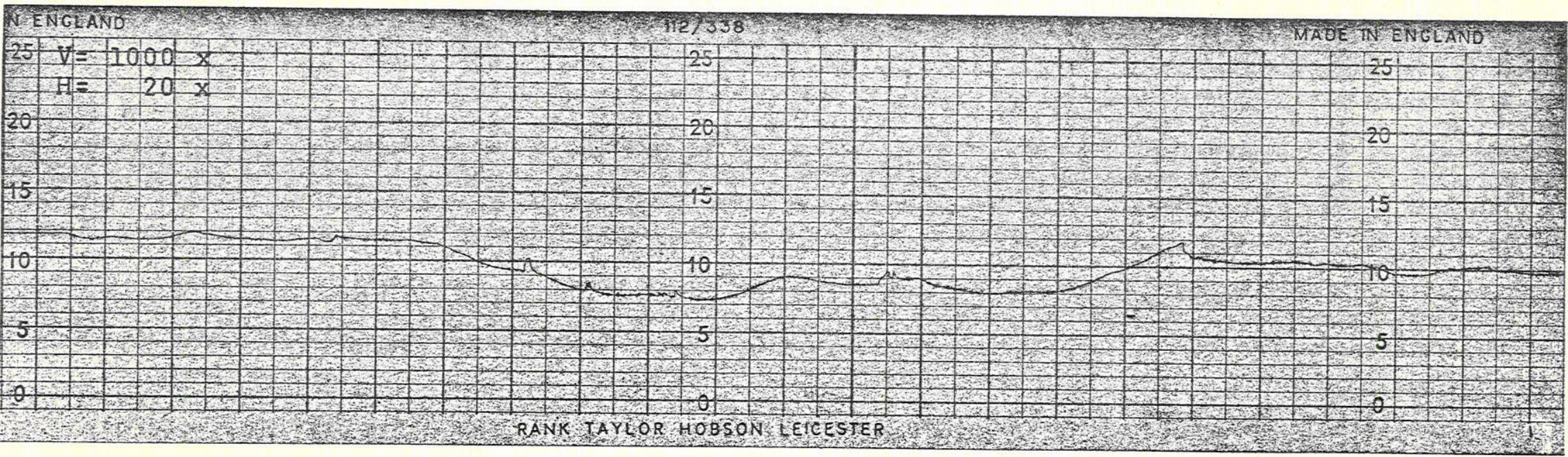

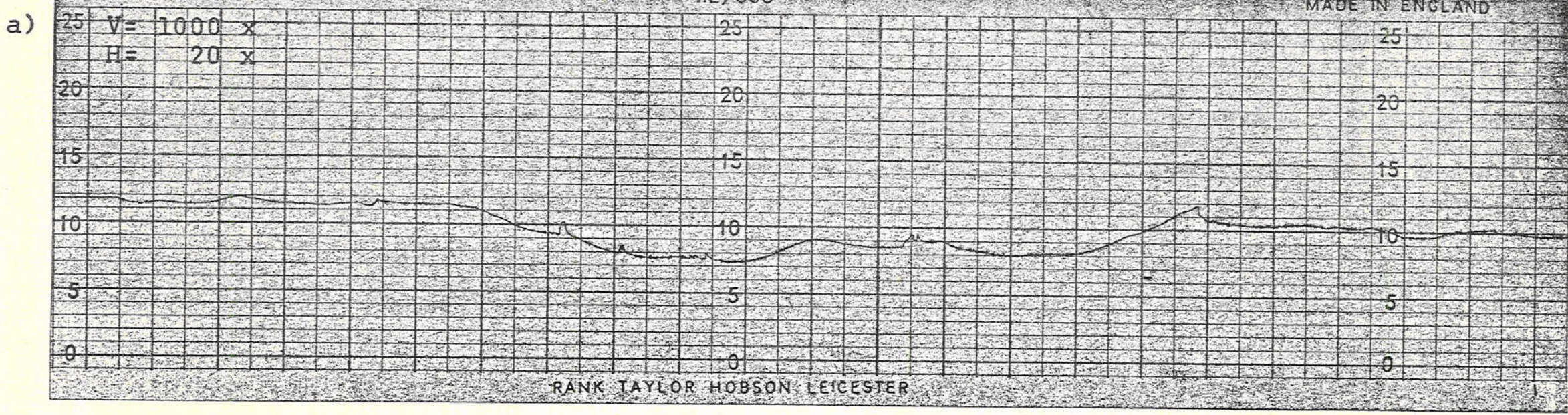

N ENGLANO

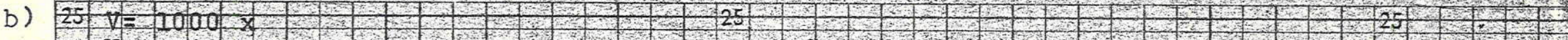

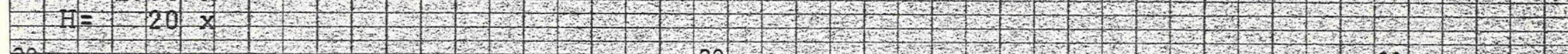

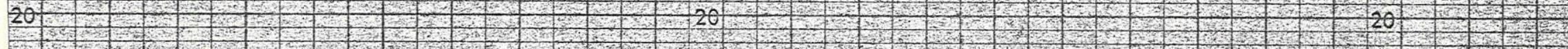

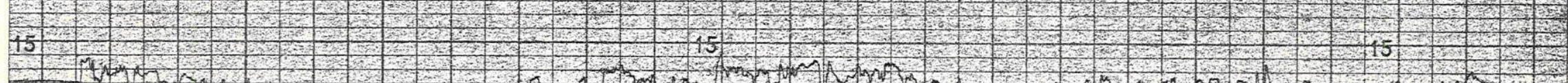

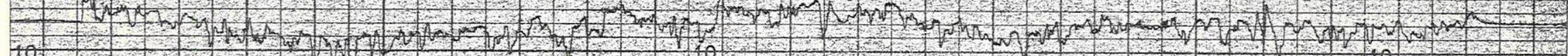

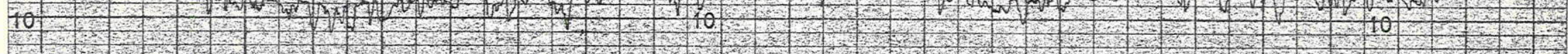

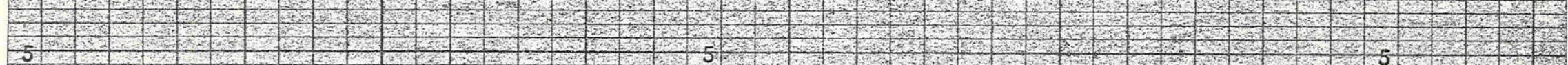

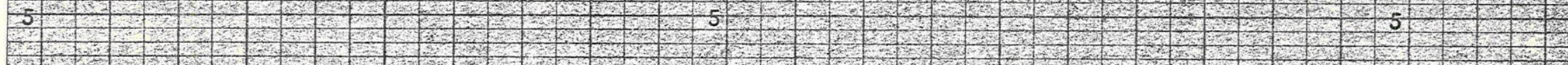

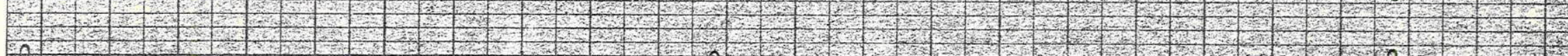

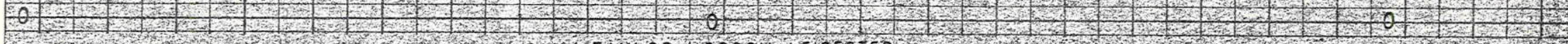

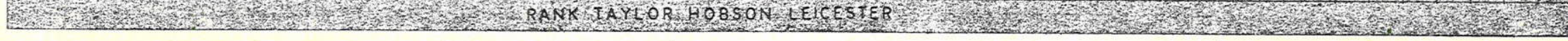

Fig.3.6 Perfis de superfície de aço frezado e lixado: (a) paralelo e (b) perpendicular às estrias 
a)

127338

MAOE INEN

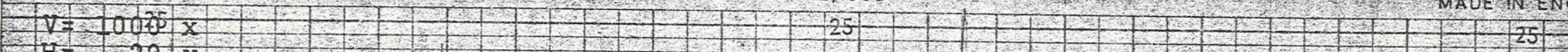
$\mathrm{H}=20 \mathrm{x}=\mathrm{N}$

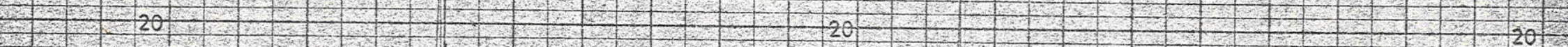

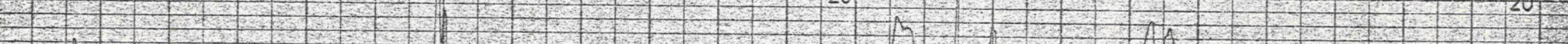

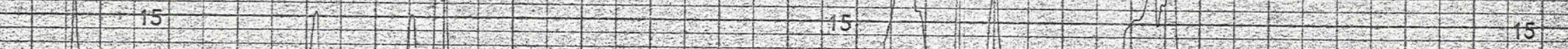

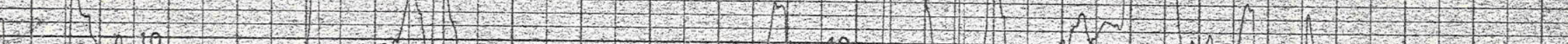

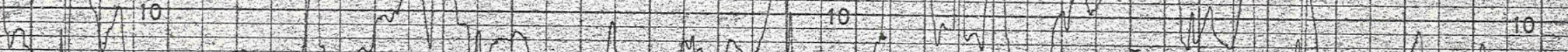

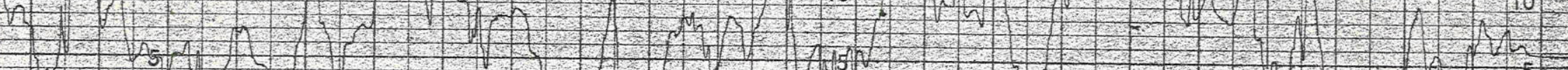

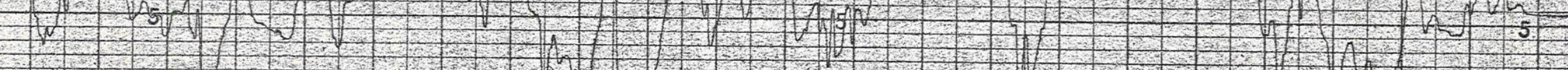

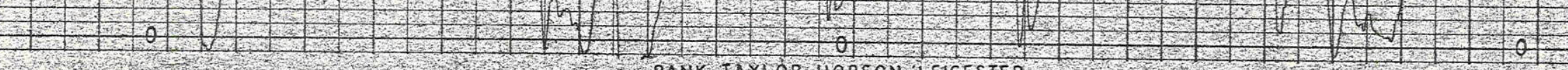

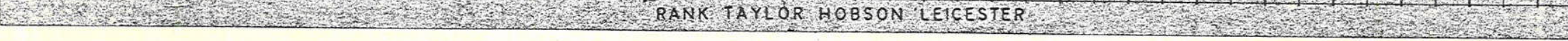

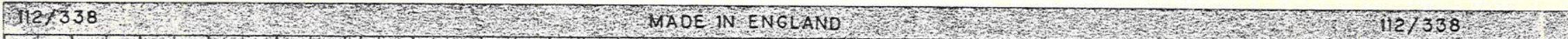

b)

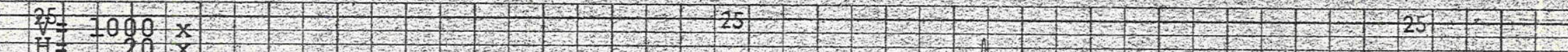

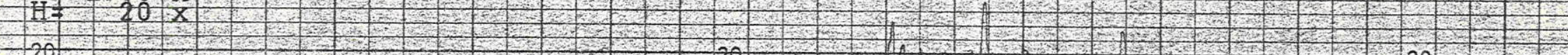

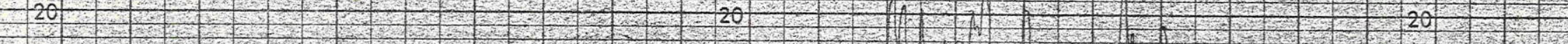

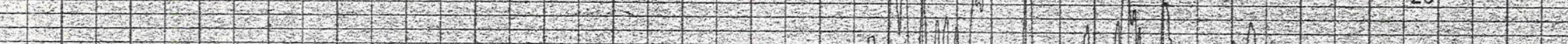

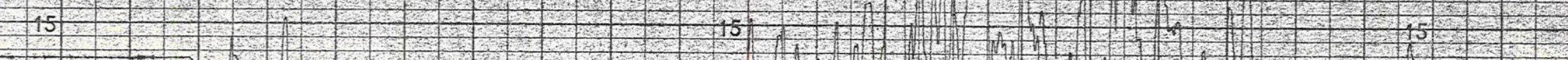

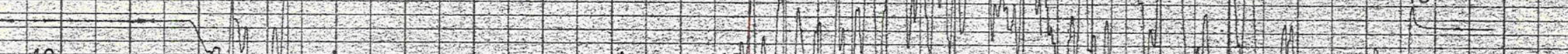

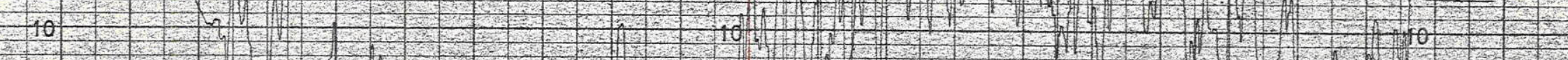

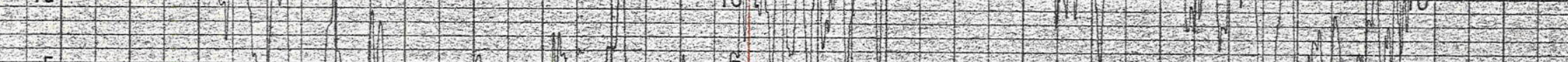

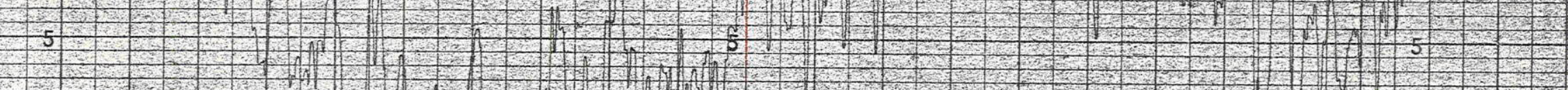

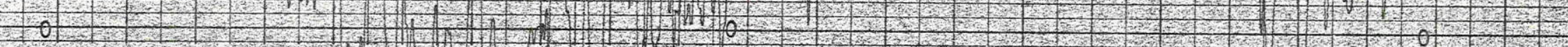
R.HOBSONLERESTER

Fig. 3.7. - Perfis de superfície de madeira aplainada e lixada:(a)paralelo e (b) perpendicular às fibras. 


\section{PROCEDIMENTO DOS ENSAIOS}

\section{1 - Preparação dos Corpos de Prova}

As amostras de solo foram recebidas na condição sêca ao ar, e desde pulverulento e desagragado abloco duro.

A ilita " Marblehead " apresentava-se como bloco duro, tendo sido submersa em água demineralizada, partida e amolgada , para sua total desagragação.

A caolinita da Georgia veio como pó seco; foi peneirada na peneira número 200, na qual cêrca de 5\% do material ficou re tido e inutilizado.

o solo " Goose Lake Flouer " veio em forma de pó.

A argila residual de basalto apresentava-se relativamente consistente, com muitos torrões, em parte desagragados na es cavação e transporte.

o silte de preenchimento de fraturas consistiu de um pó, obtido por raspagem do testemunho de sondagem.

Para todos os solos, foi usada água demineralizada para mistura e amolgamento dos mesmos. As amostras foram conservadas em sacos plásticos em câmara úmida, pelo menos durante 3 dias, para completa homogeneização na distribuição da umidade, antes da determinação dos seus limites de liquidez e plasticidade.

Apōs a determinação desses limites, cada amostra foi rea justada em sua umidade, de tal forma a ter um teor de umidade igual ao do seu respectivo limite de liquidez. Os teores de umi dade foram conferidos periodicamente.

Permitiu-se um periodo de descanço de cêrca de um mês an 
4.2

tes de se realizar quaisquer ensaios de cisalhamento direto.

A presença do corpo de prova para o ensaio de cisalhamen to direto consistiu do procedimento descrito a seguir. Uma quan tidade de solo, necessária para o ensaio, era separada do resto da amostra, e completamente amolgada por espátula em placa de ví dro. O solo era então moldado entre duas placas metálicas dentadas e perfuradas, com auxílio de um gabarito metálico com as dimensões internas iguais às da amostra. A amostra era então co locada na caixa do equipamento de ensaio entre duas placas de pe dra porosa, usadas para permitir a drenagem da amostra. Um es quema dessa montagem pode ser visto na Figura 4.1

Para o ensaio de contactos entre solo e rocha, o seguinte procedimento foi empregado. As placas de rocha foram serradas com disco de serra diamantada com água para o devido resfriamento. Para as superfícies polidas utilizou-se mesa rotativa de aço para produção de secções delgadas e abrasivo Carborundum nümero 1.200 , que possue um diâmetro médio de partículas de ordem de 6 micra. O polimento foi feito em vārios estágios, reduzindo-se progressivamente a dimensão do abrasivo. A superfície das amos tras de rocha foi depois lavada com detergente e enxaguada generosamente. A dimensão das placas quadradas serradas foi de 5,8 a $5,9 \mathrm{~cm}$., com cêrca de $1 \mathrm{~cm}$. de espessura. Essas placas foram fi xadas à metade inferior de caixa do equipamento de ensaio, com a superfície a ser ensaiada sobressaindo cêrca de $0,5 \mathrm{~mm}$ a $1 \mathrm{~mm}$ da borda da caixa ( plano de cisalhamento). Para isso, foram usa dos calços e fôlhas metálicas de espessuras variadas para ajuste necessärio; tambēm, como a área da placa de rocha era ligeiramen te menor que o espaço da caixa para contê-la, as placas foram firmemente afixadas lateralmente por meio de cunhas de folhas me tálicas. Os corpos de prova de solo, para compor o corpo de prova composto, foi preparado do mesmo modo como descrito acima para o ensaio do solo sōzinho, com a excessão de que as espessuras livres eram menores. Em seguida as duas partes do espécimen eram montadas, conforme ilustrado no esquema da Figura 4.1. As Figuras $4.2 a$ e $4.2 b$ são fotografias que mostram um corpo de - 
4.3

prova de contacto solo-rocha, respectivamente, antes e depois de ensaio de cisalhamento direto.

\section{2 - Descrição do Equipamento de Cisalhamento}

Em ambas as fases de ensaios, foi usado o equipamento de cisalhamento direto comercialmente fabricado pela WYKEHAM FARRANCE ENGINEERING LTD., modêlo SB-1, do tipo deformação con trolada, mostrado pela foto da Figura . .4. . O equipamento permite variação de velocidades de deslocamento, podendo-se obter 25 diferentes velocidades, variando de aproximadamente 1,2 a $0,0006 \mathrm{~mm} / \mathrm{min}$. Antes da realização dos ensaios foi feita uma conferência das velocidades do aparelho com as constantes no ca tálogo, sem se ter constatado diferença significativa. A caixa bipartida horizontalmente, pode acomodar espëcimes de $6 \mathrm{x} 6 \mathrm{~cm}$. . O esquema da Figura 4.3 indica que a parte inferior da caixa, apoiada sôbre esferas de aço, é empurrada por um êmbolo a uma ve locidade constante, o que produz a rutura do corpo de prova,pelo fato de a parte superior da caixa ser apoiada por um anel dinamo métrico, o qual permite medir a fôrça transmitida à caixa supe rior, ou seja, a própria resistência ao cisalhamento. A medida da fôrça é feita com auxílio de um micrômetro de precisão, afixa do diametralmente à parte interna do anel dinamométrico, convertendo-se a deformação em esforços por meio de curvas de cali bração do conjunto. A deformação sofrida pelo anel dinamométrico deve ser subtraída do desıocamento horizontal sofrida pela caixa inferior, também medida por micrômetro de precisão, a fim de se obter o deslocamento absoluto de uma parte da caixa em relação à outra. O deslocamento horizontal da caixa inferior é limitado a cêrca de $0,8 \mathrm{~cm}$.

As tensões normais são aplicadas à tampa da parte supe rior do corpo de prova através de pesos colocados em uma canga lha livre, apoiada puntualmente à tampa por esfera de aço. As 


\section{4}

deformações verticais dos espécimes ensaiados foram observados por micrômetro de precisão.

A precisão dos micrômetros utilizados é de 1 micron, ou equivalente, com excessão do micrômetro de medida dos deslocamen tos horizontais, que é de 10 micra.

o equipamento utilizado na segunda fase dos ensaios, além das características acima, possui ainda engates especiais para permitir realizar ensaios suscessivos com reversão do deslo camento, visando alcançar a resistência residual. Antes de ini ciar cada reversão torna-se necessārio relaxar a tensão do anel dinamométrico e adotar nova referência inicial para o micrômetro do anel.

\section{3 - Ensaios de Cisalhamento Direto}

Após a montagem do corpo de prova na caixa de ensaio, a caixa foi instalada no equipamento de ensaio, com água demineralizada à tôda sua volta para impedir perda de umidade. Após essa instalação, a carga normal foi aplicada, tendo sido restrita a incrementos iniciais máximos de cêrca de $0,2 \mathrm{Kg} / \mathrm{cm}^{2}$. As ${ }^{2}$ tensões normais mais altas aplicadas foram da ordem de $3 \mathrm{~kg} / \mathrm{cm}^{2}$, correspondendo à capacidade nominal do equipamento para as dimen sões da caixa de 6 × $6 \mathrm{~cm}$.

As amostras foram completamente adensadas, tendo-se con trolado o adensamento pela construção concomitante de gráfico tempo vs. recalque para cada estāgio de aplicação da tensão normal, conforme recomendado por Taylor ( 1967 ), garantindo-se assim o completo adensamento primário.

Imediatamente antes da aplicação da tensão cisalhante, os parafusos de segurança foram retirados e foi dado um espaçamento conveniente entre as duas partes da caixa, por meio de parafusos espaçadores, a fim de evitar contacto entre as mesmas, o que introduziria um atrito adicional. Em seguida, o motor foi aciona- 
4.5

do para causar o deslocamento entre as caixas. As leituras dos vários micrômetros foram feitas a intervalos julgados convenientes para a boa definição de ensaio.

Os parafusos espaçadores foram soltos após o anel dinamo mētrico acusar alguma carga, para auxiliar o suporte da caixa superior e assim manter o espaçamento imprimido.

A velocidade de cisalhamento empregada variou para várias amostras, de acôrdo com o tempo requerido para 100\% de adensamento, e foi calculado de conformidade com as anālises desenvolvidas por Gibson e Henkel ( 1954 ), tambēm referidas por Hvorslev ( 1960 ). Como verificação da velocidade de deformação assim calculada foram executados alguns ensaios adicionais no so lo " Goose Lake Flour ", tanto sob a velocidade calculada como em três outras velocidades, sendo a menor delas da ordem de 1/25 da calculada. Tendo-se obtido mesmas resistências máximas em to dos êsses ensaios, julga-se que as velocidades calculadas permitem amplamente a drenagem dos solos, para evitar o desenvolvimen to de pressões neutras. E digno de nota que Hvorslev ( 1960 ) considera os valores calculados com base na teoria de Gibson e Henkel como conservadores.

Os ensaios foram conduzidos atē as máximas deformações permitidas pelo aparelho $(0,8 \mathrm{~cm})$; em alguns casos, como recur so para obter maiores deformações, foram feitos ensaios com re versões.

Após o fim do ensaio a água demineralizada que inunda as caixas foi succionada, os pesos removidos, as caixas desmontadas e removido o excesso de água nas suas bordas.

A superfície cisalhada era examinada e logo uma porção do espécimen colhido da sua parte central para determinação do teor de umidade inicial.

\section{4 - Representação Grāfica}

As tensões cisalhantes e as normais foram obtidas divi - 


\section{6}

dińdo-se, respectivamente, as cargas tangencial e vertical pela área do corpo de prova a um determinado deslocamento. A área in cial dos ensaios é de $36 \mathrm{~cm}^{2}$.

Concomitantemente à execussão dos ensaios, para possibilitar um bom acompanhamento, foram elaborados gráficos com cur vas de resistência ao cisalhamento vs. deslocamento. Para propósito de acompanhamento, a área do corpo de prova foi considerada constante, com excessão dos gráficos da argila residual e de silte de preenchimento de fratura. Um exemplo esquemático de tal gráfico é fornecido na Figura 4.5, por meio das curvas $\mathrm{B}_{1}$ ou $\mathrm{B}_{2}$. A curva A representa um ensaio hipotético em amostra indeforma da de argila, onde apōs fornecer um pico na curva, $\tau$ māx. , a resistência ao cisalhamento decresce até alcançar um valor mínimo, constante, a despeito da continuação do deslocamento, que tem sido designado como resistência residual, Zres, na termino logia comum de Mecânica dos Solos.

As curvas $\mathrm{B}_{1}$ e $\mathrm{B}_{2}$ representam curvas hipotēticas de ensaios em amostras amólgadas, típicas dos resultados dêste estudo para amostras ensaiadas, respectivamente, a mëdias e baixas ten sões normais. A curva $B_{1}$ exibe um pico, seguido por uma queda na resistência. Acredita-se que o valor final da resistência ao cisalhamento para os solos amolgados ( curvas $\mathrm{B}_{1}$ e $\mathrm{B}_{2}$ ) seja a mesma que a resistência residual obtida para os solos indeformados ( curva A), se o amolgamento foi o único fator variável. Uma vez que o equipamento usado limita os deslocamentos a cêrca de $0,8 \mathrm{~cm}$, julgou-se conveniente introduzir os têrmos $\checkmark$ min. obtido, para indicar a menor resistência ao cisalhamento alcançada a um determinado deslocamento. No caso da referência ao valor mínimo obtido corresponder ao deslocamento máximo per

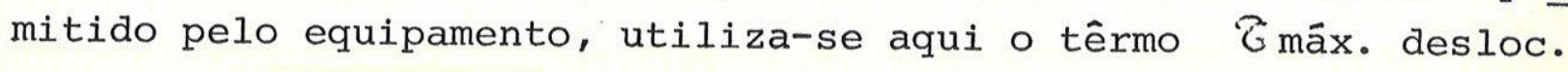

Como se pode constatar do exame da Figura $4.5, \tau$ min. -

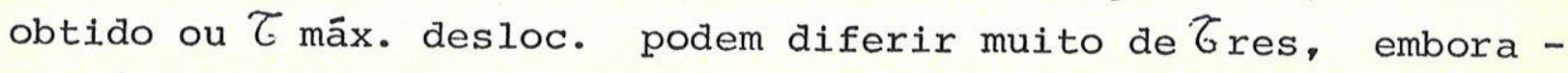
em vários casos podem-se aproximar muito e práticamente coincí dir com o $\tau$ res.

No esquema da Figura $4.6(a)$ então representadas duas - 


\section{7}

curvas de resistência ao cisalhamento vs. deslocamento, corres pondendo a um ensaio feito a baixa tensão normal ( Ensaio "a" ) e outro a tensões normais mais altas ( Ensaio "b") . Os dois pe quenos esquemas de corpo de prova mostram como a área do mesmo diminui com o deslocamento crescente, embora a carga normal permanece constante; correspondem, respectivamente, às situações inicial e final de ensaio. Em consequência, ocorre um correspondente aumento da tensão normal no curso do ensaio. Para o Ensaio "a", o valor da tensão normal é $\widetilde{\sigma}_{n} a_{1}$ na rutura e, no final do ensaio será $\sigma_{\mathrm{n}} \mathrm{a}_{2}$, algo maior. Em decorrência, os resultados representando aquelas duas situações estarão em diferentes posições com relação à escala das abcissas, como exemplificado pelo diagrama da Figura 4.6(b), e não na mesma vertical conforme convencionalmente vem sendo adotado.

Esta mesma Figura indica como os pontos podem ser ligados para fornecer a envoltória de resistência máxima, e também como se obtem a envoltória dos valôres de resistência mínima obtida , correspondentes ao deslocamento máximo dos ensaios. Estas envoltórias são comumente empregadas para a estimativa da resistência do material, às tensões normais determinadas.

Se se proceder a uma correção dos valores de $\tau$ e de $\sigma_{n}$, levando em conta a mudança da área de contacto do corpo de prova, é possível traçar o caminhamento ou a trajetōria dessas tensões, durante um ensaio. Duas dessas trajetórias estão esquematicamente representadas na Figura $4.6(\mathrm{~b})$ e, com mais detalhe, na Figura 4.7 . Êssas linhas foram aqui chamadas de " trajetórias de tensão ", usando-se aspas para distingui-las das verdadeiras trajetórias de tensões quando o estado de tensões è perfeitamente reconhecido, e que têm sido referidas em conexão com ensaios de compressão triaxial. A Figura 4.7 mostra esquematicamente três " trajetórias de tensão ", correspondendo aos tipos encontrados nos ensaios procedidos, e representando três ensaios a tensões normais diferentes. As linhas A e B representam as envoltórias de resistência máxima e mínima obtida.

Uma " trajetória de tensões " é considerada completa se, 
4.8

após alcançar um certo ponto "a", como nos casos 2 e 3, sua in clinação mudar e prosseguir numa trajetória ascendente, paralela ou coincidente à curba B. Tais trajetōrias são consideradas re presentativas de ensaios em que os valôres da resistência resí dual jā foram alcançadas, ou quase alcançadas, o que é situação satisfatória para fins práticos. Acredita-se que os ensaios exibindo uma trajetória completa já foram conduzidos a um desloca mento satisfatório, além do qual não deverá ocorrer redução apre ciāvel da resistência.

O aparecimento de " trajetórias de tensão " é considerado mais uma decorrência de ensaio de laboratório, pois raros seriam os casos de campo em que ocorreria uma redução da área de contacto. Este efeito, contudo, é equivalente ao de um ensaio com tensão normal crescente, e pode-se imaginar condições de campo em que a tensão normal cresce, após ter-se alcançado a re sistência residual, como por exemplo a superposição de fases tectônicas ou a construção de obras de engenharia em terrenos an teriormente cisalhados.

Uma trajetória incompleta ( caso 1 ) é aquela em que os deslocamentos foram insuficientes para alcançar o ponto "a" aci ma referido. Assim, os resultados relativos ao deslocamento má ximo do ensaio 1 não são perfeitamente comparáveis aos dos̃ ensaios 2 e 3 .

Vários casos reais de " trajetōrias de tensão " estão in cluidos nos resultados de ensaios apresentados no ítem 5 .

Deve-se ainda mencionar que Lombardi e Dal Vesco ( 1966 ) e Locher ( 1968 ) apresentam " trajetórias de tensão " de ensaios de cisalhamento direto, mas que são algo diferentes da trajetōria aqui relatada, pois representam a variação da ten são normal registrada durante todo o ensaio, que se restringiu a superfícies de rocha.

Também, Bishop et al ( 1971 ) apresentam resultados comparativos entre ensaios de torsão e de cisalhamento direto com reversões multiplas, notando a coincidência de valôres de re sistência mînima apōs o pico, em cada reversão, mas criticando o 


$$
4.9
$$

fato de que após êsses pontos os resultados fornecem valôres crescentes. Acredita-se que esses mesmos dados, se propriamente tratados, forneceriam excelentes exemplos de " trajetōria de tensão " do tipo aqui descrito. 

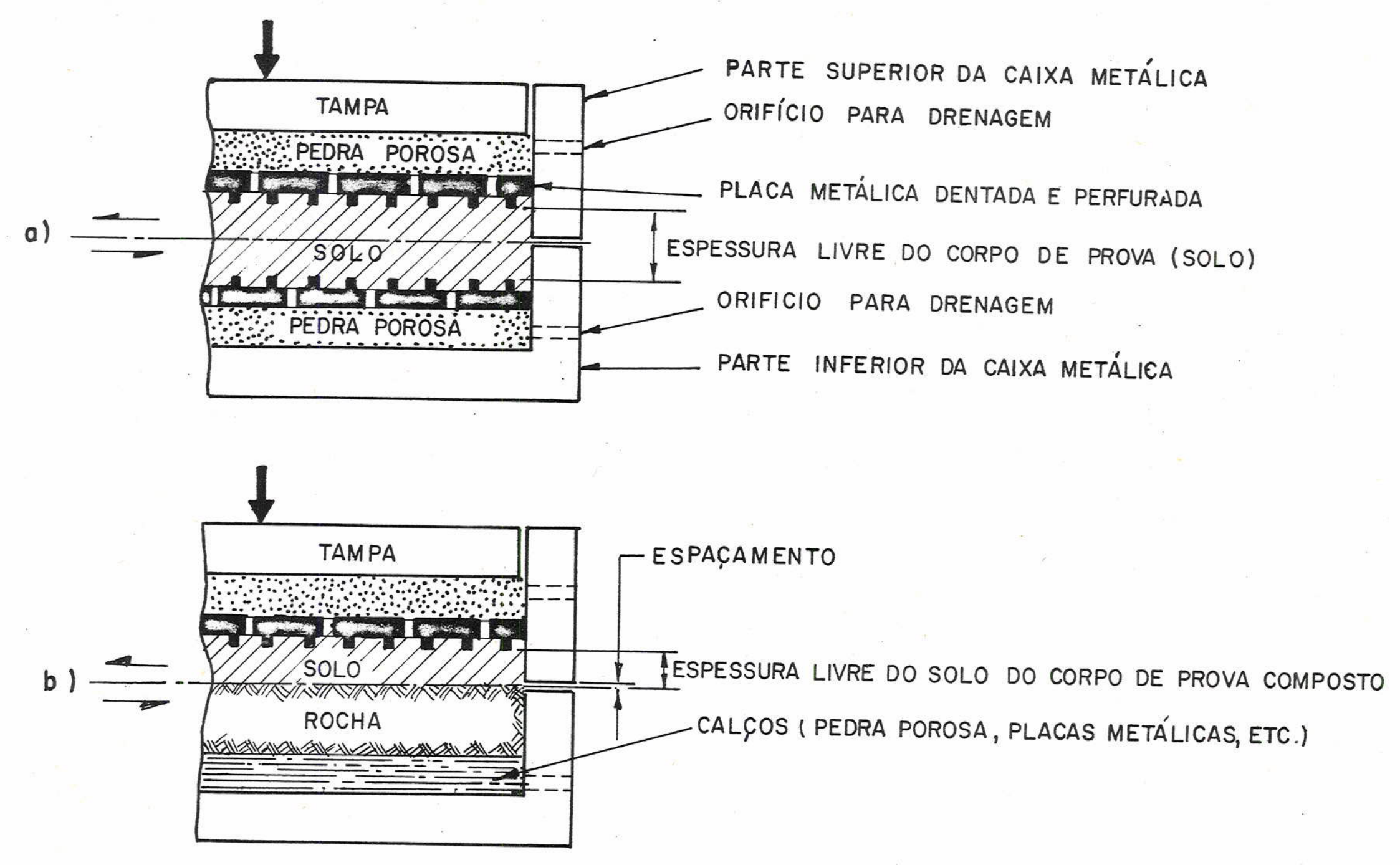

FIG. 4.1 - ESQUEMA DA MONTAGEM DOS CORPOS DE PROVA PARA ENSAIO 

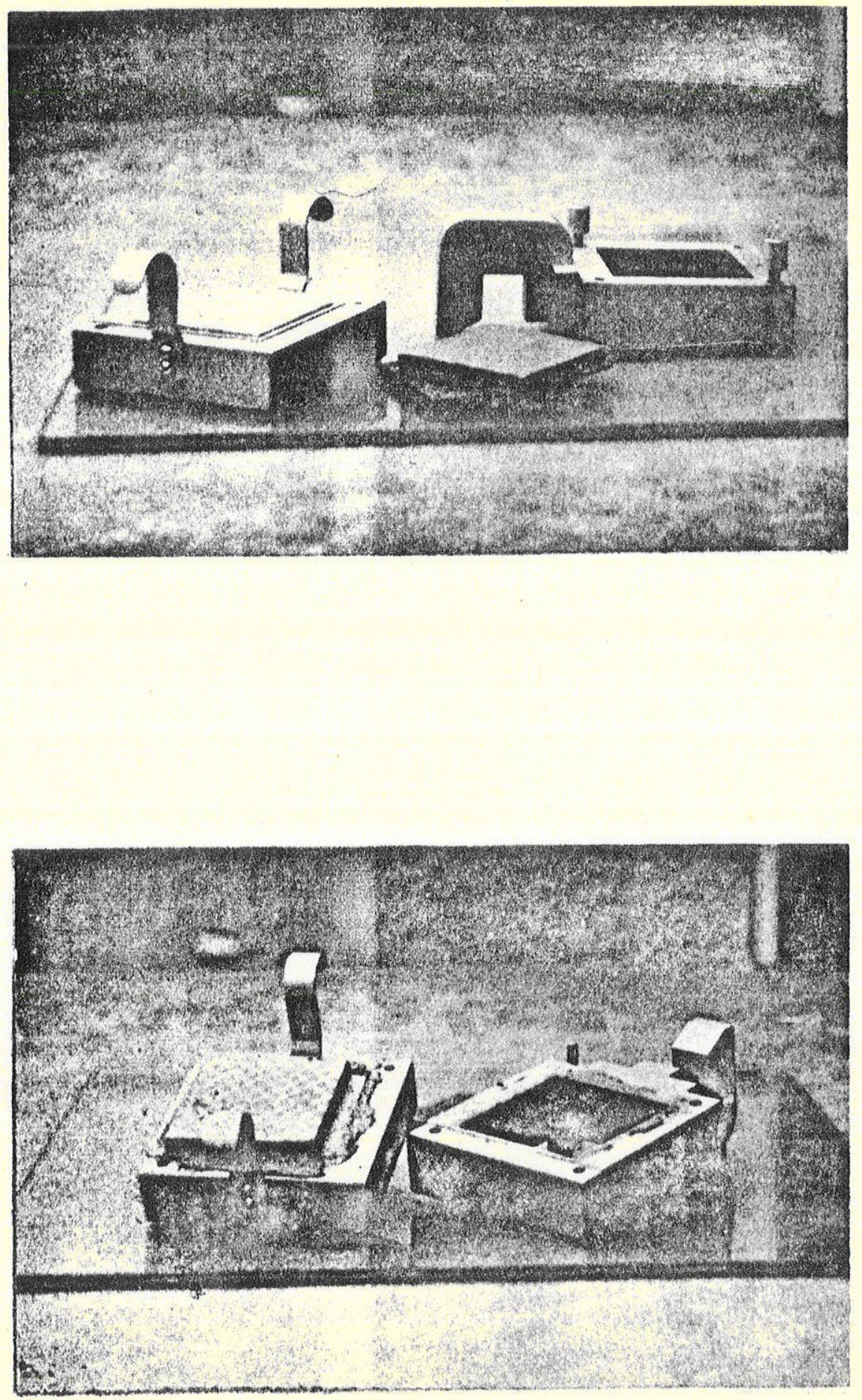

Figura 4.2 - FOTOGRAFIAS DE UM CORPO DE PROVA PARA ENSAIO DE CONTACTO SOLO ROCHA (a) ANTES E (b) DEPOIS DO ENSAIO. 


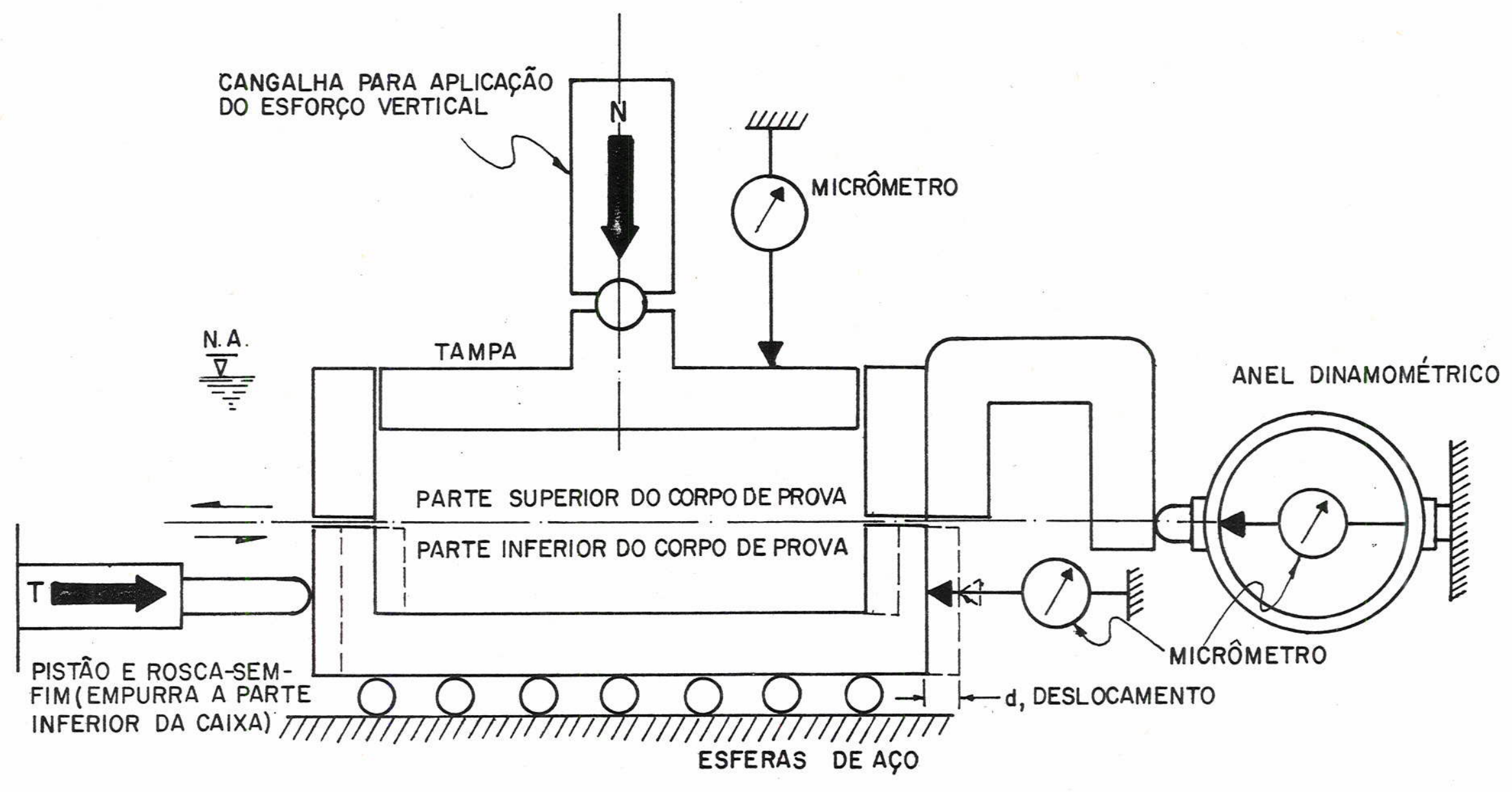

FIG. 4.3 - ESQUEMA DO EQUIPAMENTO DE ENSAIO DE CISALHAMENTO DIRETO 


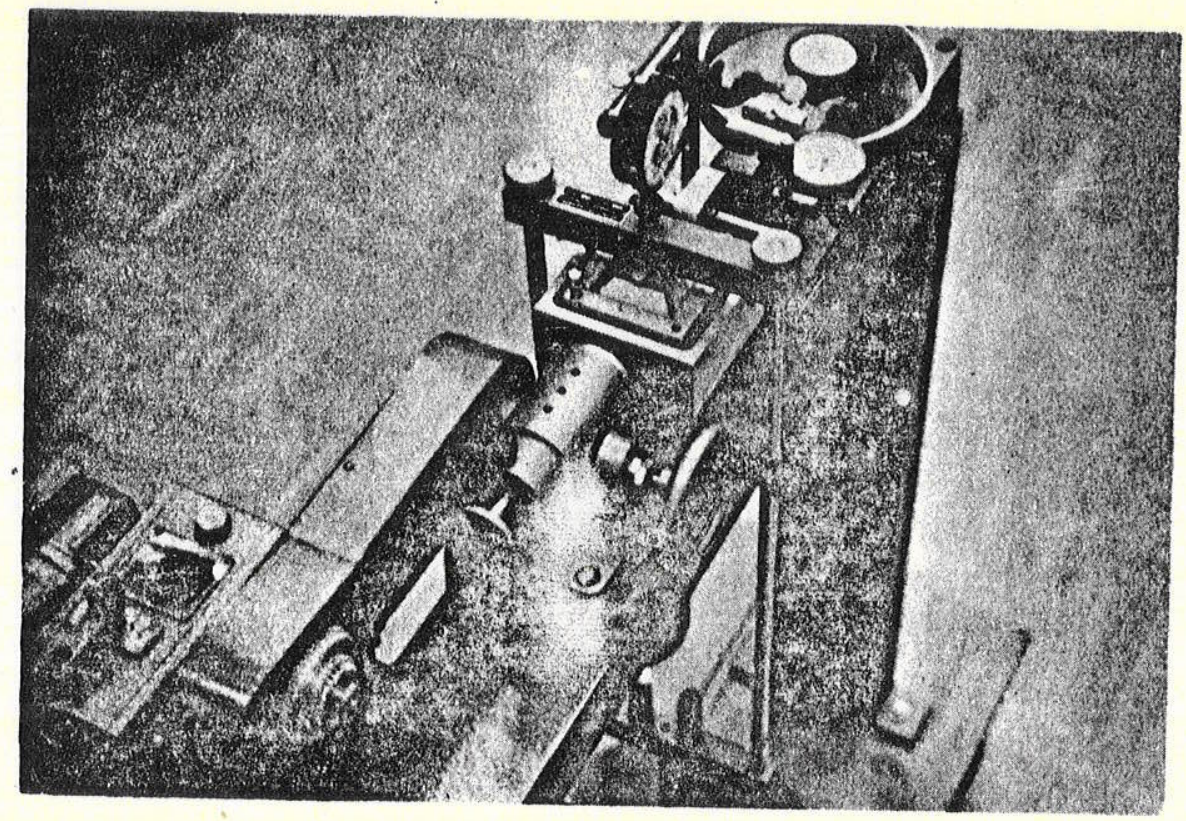

Figura 4.4 - FOTOGRAFIA DO EQUIPAMENTO DE EN SAIO DE CISALHAMENTO DIRETO. 


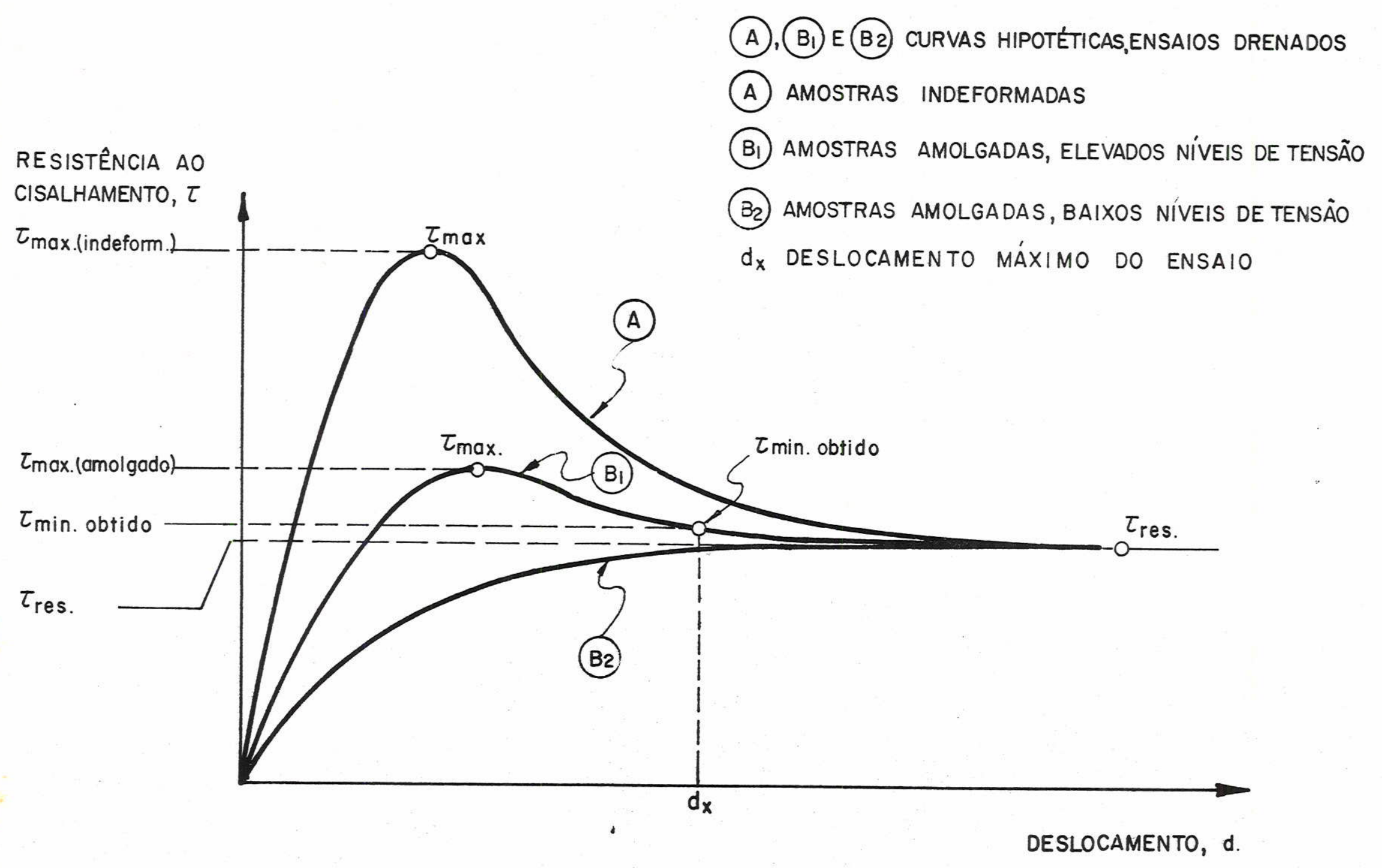

FIG. 4.5- ESQUEMA ILUSTRATIVO DA TERMINOLOGIA UTILIZADA PARA DESIGNAR OS VARIOS VALORES DE RESISTÊNCIA AO CISALHAMENTO 


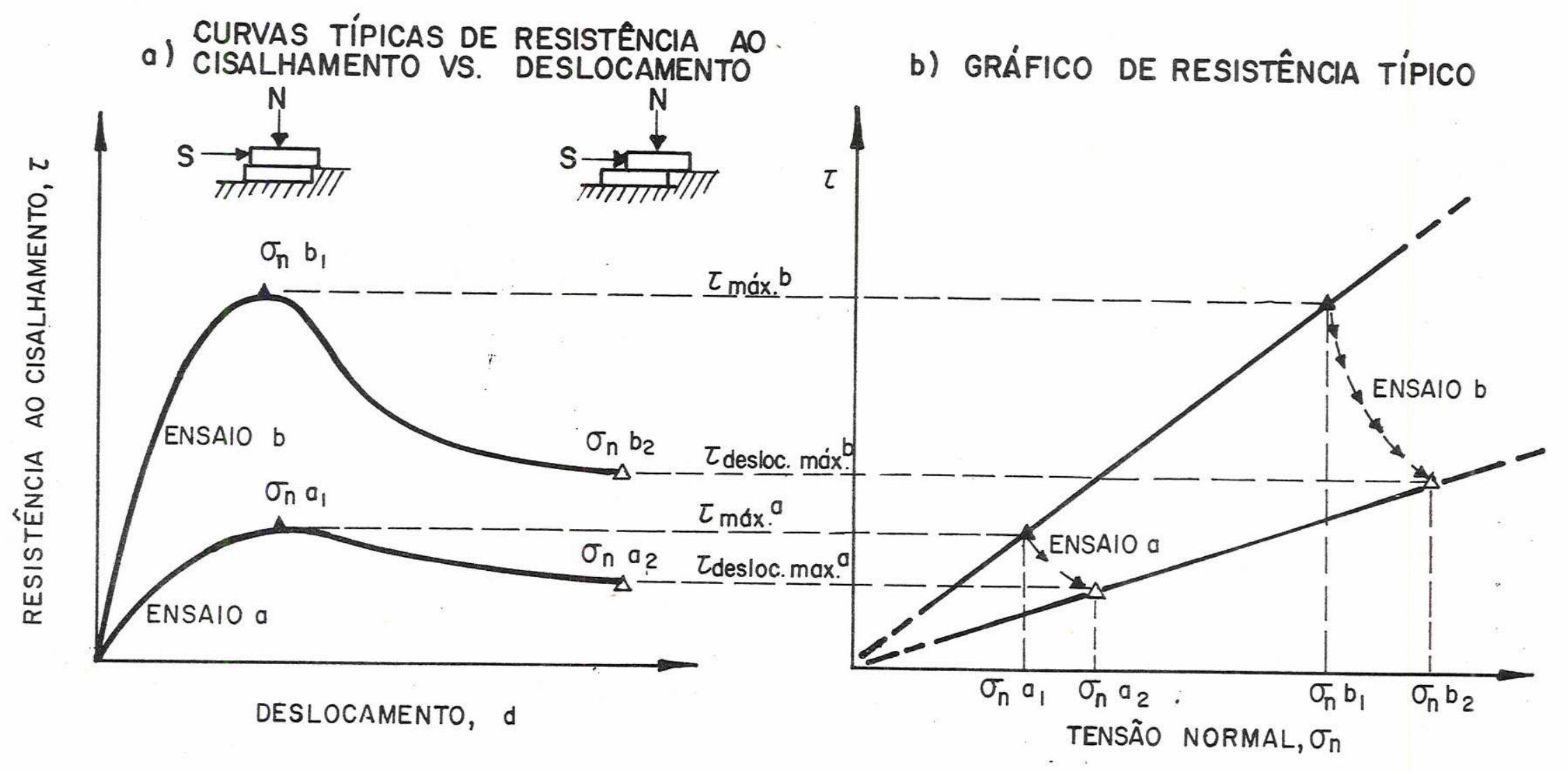

FIG. 4.6- ESQUEMA ILUSTRATIVO DA CONSTRUÇÃO DO GRÁFICO DE RESISTÊNCIA 


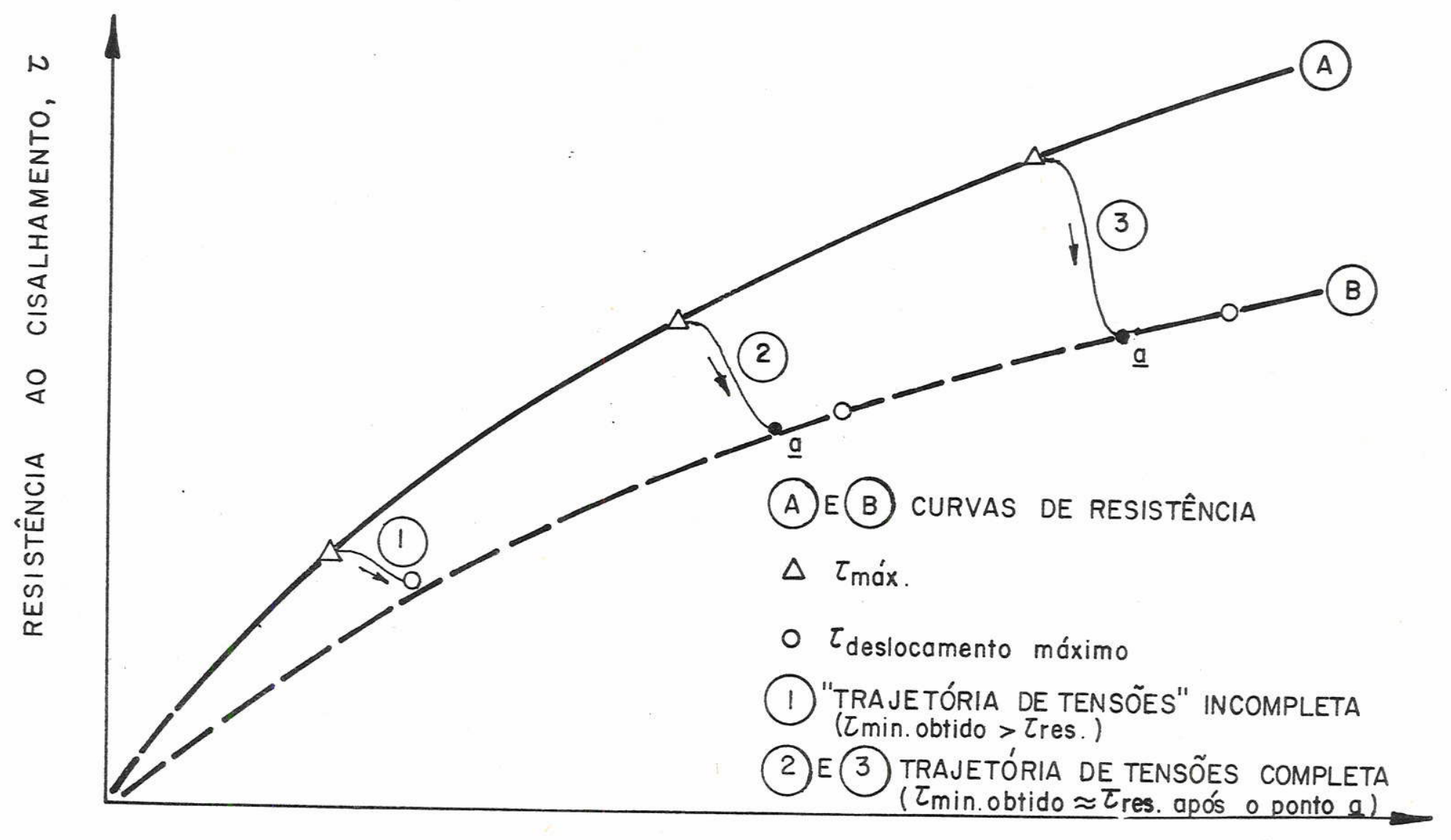

TENSÃO NORMAL, $\sigma_{n}$

FIG. 4.7 - ESQUEMA ILUSTRATIVO DE EXEMPLOS DE DIFERENTES "TRAJETÓRIAS
DE TENSÃO) 
5. APRESENTAÇÃO E DISCUÇÃO DOS RESULTADOS

\section{1 - Solo " Goose Lake Flour " e seus Contactos}

As curvas de resistência ao cisalhamento vs. deslocamento obtidas para êsse solo são apresentadas na Figura 5.1, correspondentes às tensões normais indicadas segundo a área inicial do corpo de prova. Pode-se ver que as curvas correspondentes às tensões normais mais baixas não apresentam um pico de resistência, o qual desenvolve-se e se torna mais pronunciado à medida que essas tensões aumentam. O desenvolvimento do pico poderia ser devido à formação de estrutura interna mais densa, devida so adensamento maior sofrido, a qual é depois destruida no cisalhamento.

Desses curvas tambēm se pode observar que a resistência residual não foi alcançada, nos limites de deslocamento permiti do pelo equipamento, talvez com excessão dos dois ensaios às mais baixas tensões normais; para as tensões mais altas, seria necessário um deslocamento muito maior para o desenvolvimento da resistência residual.

A velocidade padrão usada para o cisalhamento desse solo foi de $0,125 \mathrm{~mm} / \mathrm{min}$, considerada suficientemente lenta para ga rantir a completa drenagem do mesmo. Essa velocidade foi estabelecida tanto por cálculo a partir do tempo de adensamento co mo experimentalmente, pela realização de alguns ensaios adicio nais sob diversas velocidades, a serem mencionados no ítem 5.7

As Figuras 5.2 e 5.3 contêm as curvas resistência ao cisalhamento vs. deslocamento dos contactos do solo com o calcá reo, respectivamente, com superfície serrada e polida, obtidas - 
5.2

em rensaios a diferentes tensões normais. Nessas curvas também pode ser apreciado, mais nitidamente ainda a formação de um pico, que já começa a se esboçar mesmo à mais baixa tensão normal utilizada e que se desenvolve com o aumento das mesmas. Ainda, com parando as curvas obtidas para o solo apenas e para seus con tactos com rocha, pode-se verificar que os solos ensaiados so zinhos fornecem picos a deslocamentos cada vez menores à medida que a tensão normal aumenta, ao passo que para os contactos ês ses picos são obtidos a deslocamentos cada vez maiores com o incremento da tensão normal. Da mesma foram, a queda da resistên cia após o pico é muito mais pronunciada para os contactos que para o solo; em ambos os casos os deslocamentos foram insuficien tes para alcançar as resistências residuais, mas já tendo-se chegado mais próximo à mesma no caso dos contactos. Em outros têrmos, a queda de resistência após o pico é muito maior para os contactos que para o solo, tanto maior quanto mais lisa for a su perfície, considerando-se a mesma magnitude de deslocamento, e quanto mais lento o cisalhamento. Jsses fatos parecem refletir que a presença da superfície de rocha deve auxiliar na orienta ção das partículas adjacentes de solo, causando a queda mais rā pida da resistência. A comparação com os ensaios dos outros so los, mostra que essa redução da resistência é mais lenta que a observada em alguns deles, atribuindo-se o fato à presença de particulas granulares de areia fina que dificultam a orientação das partículas micáceas junto à superfície de contacto, processo em que a velocidade mostra-se significativa.

Nas curvas correspondentes aos ensaios dos contactos , nas tensões normais mais elevadas, observa-se que após o pico a resistência permanece constante por um certo deslocamento para depois apresentar a pronunciada redução. Tal fato poderia indí car que estaria ocorrendo um mecanismo composto de rutura, uma vez que o contacto envolve dois tipos de material ( solo e rocha ), e que teriam diferentes comportamentos; sua curvas apre sentariam picos a diferentes valôres de deslocamento. Assim, as curvas dos ensaios de contactos poderiam representar uma combina ção daquelas duas outras curvas. o único paralelo encontrado - 
na bibliografia ẻ apresentado por Leussink e Kirchenbauer (1967) a propósito da aplicação dos valôres de resistência ao cisalha mento de descontinuidades à estabilidade de taludes, que prog nosticam curva mais ou menos similar, resultante de duas outras curvas, com picos a diferentes deslocamentos, e correspondentes a duas porções de uma fratura preenchida e com diferentes espessuras.

Com o mesmo procedimento descrito no item 4.4 e ilustrado na Figura 4.6, foi construido o gráfico de resistência da Fí gura 5.4, com os dados dos ensaios no solo " Goose lake Flour "e de seus contactos com calcáreos. Os símbolos cheios represen tam resistências máximas, obtidas no pico das curvas, e forne cem as envoltórias de linha contínua. Os símbolos vazios representam as condições ao máximo deslocamento possível, e fornecem as envoltōrias interrompidas.

Constata-se no gráfico que as resistências máximas do contacto solo-rocha polida fornecem uma envoltória praticamente reta, sendo um pouco inferior à do solo, ligeiramente curva. No entanto, as envoltórias correspondendo às resistências refe rentes aos deslocamento máximos são muito menores para os con tactos que para o solo, embora sejam relativamente paralelos.

Os resultados apresentados nesse gráfico revelam sè con sistentes, em tôda a gama de tensões normais empregadas, pelas envoltōrias regulares que podem ser traçadas. Os resultados dos contactos com rocha serrada apresentam relativa dispersão, que é atribuida ao fato de que diferentes espécimes foram usados para a maioria dos ensaios, nos quais as irregularidades devidas à serragem variaram de espécimen para espécimen. Nos casos em que foi usada uma única superfície para uma série de ensaios os re sultados apresentaram boa concordância. Êsse problema não ocorreu para a rocha polida, devido à uniformidade da superfície nos vários espécimes, De acôrdo com as irregularidades da superfície serrada, a resistência ao cisalhamento do contacto pode ser igual ou menor que a do solo, sendo menor quando a superfície apresentar menor rugosidade. Em cerca de dois casos a resistên 


\section{4}

cia do contacto com rocha serrada forneceu valôres cêrca de 5\% maiores que a do solo. A fim de verificar essa ocorrência, fo ram repetidos alguns ensaios à tensão normal de aproximadamente $3 \mathrm{Kg} / \mathrm{cm}^{2}$, com o mesmo espēcimen de rocha, tendo-se obtido en tão valôres consistentemente iguais. Esses ensaios, em que a única variāvel foi a velocidade de cisalhamento, serão tambēm referidos no ítem 5.7.

As maiores reduções da resistência após o seu valor māxí mo, no limite de deslocamento imposto, são as em que a superfície polida foi utilizada, sendo as menores as do solo.

As "trajetórias de tensão " ilustradas na Figura 5.4 são para ensaios de contactos de solo com rocha polida. Elas são consideradas de desenvolvimento incompleto, embora pela sua forma indiquem ser quase-completas. Não fôra a heterogeneida de mineralógica do solo, onde os grãos de quartzo podem ter difi cultado a orientação das partícủlas de argila, as trajetórias teriam provavelmente se completado.

\section{2 - Caolinita da Georgia e Seus Contactos com 으 Calcāreo}

As curvas de resistência ao cisalhamento vs. deslocamentos dos ensaios da caolinita constam da Figura 5.5, e as curvas correspondentes aos ensaios dos contactos com superfícies serradas e pölidas constam, respectivamente, das Figuras 5.6 e 5.7. No caso do contacto com superfície polida, o ensaio com a tensão normal mais elevada foi repetido por ter apresentado o " modo composto " de rutura, conforme acima mencionado. A repetição cons tou de ensaio em novo espécime, razão pela qual se explica o pico a diferente altura, e também de um segundo cisalhamento no mesmo corpo de prova. Os três ensaios formeceram aproximadamente a mesma resistência mínima obtida. o gráfico de resistên cia da caolinita e de seus contactos com o calcáreo é apresenta 
do na Figura 5.8. Um nümero um pouco menor de ensaios foi realizado nessa sērie, em comparação com a anterior, mas são bastante consistentes, e apresentaram cs mesmos comportamentos dos en saios no solo " Goose Lake Flour ".

Constata-se da Figura 5.8 que a resistência máxima dos contactos com rocha polida é consideravelmente menor que as do solo. Nos ensaios dos contactos com rocha serrada foi usado o mesmo espécimen de rocha, resultando valôres intermediärios en tre os do solo e contacto com rocha polida. A queda de resistẽncia após o pico é um pouco maior no caso da superfície polí da que na serrada, embora sejam semelhantes e ambas terem apresentado valôres muito inferiores à resistência mínima obtida do solo.

A"trajetōria de tensões" para o ensaio em solo à tensão normal de aproximadamente $0,25 \mathrm{Kg} / \mathrm{cm}^{2}$ é incompleta, revelando que seria necessārio maior deslocamento para que a mesma se com pletasse. Já para o ensaio a aproximadamente $2,7 \mathrm{Kg} / \mathrm{cm}^{2}$ a "tra jetória de tensões" é completa, o que indica que a resistência residual jā foi alcançada, pelo menos para fins prāticos.

As " trajetórias de tensão " dos dois ensaios de contactos com superfícies polidas são completas. Uma delas, correspon dente à tensão normal de cêrca de $2,7 \mathrm{Kg} / \mathrm{cm}^{2}$ apresenta-se dupla, com um estāgio intermediário. Este fato deveu-se ao excessivo espaçamento dado entre as caixas nesse ensaio e a " trajetória de tensões " é interpretada como sendo o resultado do desenvolvimen to da rutura em duas etapas: primeiro, a rutura se deu no solo ( notar que a primeira parte da trajetōria termina em perfeita coincidência com a envoltōria de resistência residuảl do solo) e, depois, no contacto, completando a trajetória.

5.3 - Ilita " Marblehead e Seus Contactos com 으 Calcáreo

Para a ilita e seus contactos foram realizados apenas - 


$$
5.6
$$

trếs ensaios em corpos de prova e dois de contacto com rocha polida, pois objetivou-se simplesmente verificar se o mesmo comportamento dos dois solos precedentes seria observado em so los de mais alta plasticidade, e se ocorreria redução da resis tência no contacto em comparação com a resistência do solo pro priamente dito.

Apesar do pequeno nümero de ensaios, os resultados, apre sentados na Figura 5.9(a) para o solo, e na Figura 5.9(b) para contactos com rocha polida, mostram essencialmente o mesmo tipo de comportamento apresentado pelos demais solos.

As resistências máximas dos contactos conforme obtidas do gráfico da Figura 5.10, são apenas ligeiramente inferiores às do solo, mas a queda de resistência após o pico é bem maior para o contacto.

\section{4 - Argila Residual de Basalto e seus Contactos com 으 Calcá- reo " Bedford " e com o Basalto Compacto.}

Conforme se depreende da programação principal esțabelecida, resumida na Tabela 1.1 , selecionou-se um solo para, além de ensaiá-lo em contactos com rocha, comparar sua resistência em contactos constituídos por diferentes tipos de rocha. Assim, a argila residual de basalto foi ensaiada em contactos de basalto e de calcáreo.

Uma vez que as comparações sôbre a resistência de contac tos e a dos solos já foram feitas, e por meio de comparação das várias envoltórias de resistência, julgou-se plenamente suficiente a comparação da resistência para variadas situações de contactos de um mesmo solo através de resistências medidas a uma única tensão normal. Assim, todos os ensaios realizados com a argila residual de basalto foram realizados sob a tensão normal inicial de $1,5 \mathrm{Kg} / \mathrm{cm}^{2}$.

A figura 5.11 contem as curvas resistência ao cisalha - 
mento vs. deslocamento desse solo e de seus contactos com o bạ salto ( superfície natural de fratura, polido e em amostra tipo sanduiche) e com o calcāreo ( serrado e polido ).

A resistêncoa do solo mostra-se bem maior que a de seus contactos. Com o basalto, nota-se claramente que a resis têncoa é menor quanto menor a rugosidade do plano de contacto, e é ainda menor para a amostra tipo sanduiche, com cêrca de $0,2 \mathrm{~mm}$ de argila e utilizando uma superfície polida e outra serrada de basalto, embora as resistências máximas sejam aprocimadamente as mesmas. A única diferença apresentada pelos picos è a magnitude do deslocamento em que os mesmos ocorrem: com o aumento da rugosidade o pico se desenvolve a maiores deslocamentos.

O.mesmo tipo de comportamento foi observado nos contactos com o calcáreo, ou seja, contacto constituido por superfí cie polida apresenta resistência menor e um pico desenvolvido a menor deslocamento, que o contacto com superfície serrada.

Um fator interessante foi observado na série de en saios com esse solo. Todos os ensaios foram executados com o so lo sempre com o mesmo teor de umidade inicial, ou seja, igual ao limite de liquidez. Controlando os teores de umidade finais, logo apōs o ensaio, verificou-se uma dispessão dos valôres de cêrca de $6 \%$ para mais e para menos com relação ào teor de umidade final para o ensaio do solo sozinho, que foi julgada uma va riação excessiva. No entanto, obtem-se perfeita congruência nesses resultados quando relacionados à rugosidade do plano de contactos, correspondendo os menores valôres do teor de umidade aos planos de maior rugosidade e vice-versa. Em um gráfico monologarítmico, com o teor de umidade final em ordenadas e a rugosidade em abcissas, obtem-se aproximadamente uma reta. A media dos valôres finais do teor de umidade para os contactos coin cide exatamente com a do solo, ou seja, 52\%.

5.5 - Silte de Preenchimento de Fraturas em Ensaio Tipo "Sanduiche" 


\section{8}

Conforme anteriormente mencionado, a quantidade de silte coletada da fratura, com espessura de $2 \mathrm{~cm}$, contida em um testemunho de sondagem de recuperação integral (Rocha, 1970 ) foi muito pouca e a única alternativa foi ensaiā-la em uma variante do ensaio de contacto, intercalando-a a dois espécimes de rocha, formando amostra tipo sanduiche.

Em decorrência disso, os ensaios foram feitos em está gios de tensão normal, tendo-se aplicado $1,0,2,0, e 3,0 \mathrm{~kg} / \mathrm{cm}^{2}$ em cada estágio, fazendo-se ainda um último a $1,0 \mathrm{Kg} / \mathrm{cm}^{2}$. Em cada estágio de tensão normal procedeu-se à reversão do sentido do deslocamento, retornando a amostra, após cada reversão, à sua posição original.

Os resultados são apresentados na Figura 5.12, por meio de curvas de resistência ao cisalhamento vs. deslocamento, cor respondendo os símbolos cheios ao movimento em sentido normal e, os vazios, às reversões. As curvas mostram-se todas uniformes com uma plataforma onde a resistência é praticamente constante em cada estágio, refletindo o escorregamento pelos contactos so lo-rocha. A única excessão consiste na curva da reversão do en saio B5, que se mostra típica de um solo, e que poderia talvez ser atribuida a uma condição momentânea do equipamento de „ensaio, ou decorrente de uma possível assimetria da amostra adquirida no estágio precedente de ensaio.

Para cada curva foram obtidos os valores no ponto de inflexão e ao final de cada curva, com o que foi construido o grâfico de resistência da Figura 5.13. Nesse gráfico, indica-se a ordem de execução dos estāgios, notando-se que com o progredir do ensaio a resistência diminue de 310 até 17\%, Para os três ú1 timos estāgios êsse valor permaneceu praticamente constante, sugerindo que tenha sido alcançada a resistência residual do solo. Para melhor esclarecer êsse ponto, contruiu-se o gräfico da Figu ra 5.14, conforme sugerido e utilizado por Bishop et al (1971) e que representa a relação da tensão normal. o patamar obtido a 17\% fortemente sugere que a resistência residual foi alcançada para fins práticos. 


\section{9}

Cabe, por último, chamar a atenção de que esses resultados são bem superiores aos do ensaio em sanduiche da mesma rocha porēm com preenchimento de argila residual, o qual fornece um ân gulo de atrito de aproximadamente 10\% ( $\mathrm{C}=0)$.

\section{6 - Resistência ao Cisalhamento das Superfícies de Rocha}

Calcāreo " Bedford " - Foram realizados vārios ensaios de cisalhamento direto em superfícies polidas e em superfícies serradas do calcāreo, tendo-se procedido, em alguns dêles, a car regamento vertical em estágios. Em todos os ensaios os corpos de prova foram submersos em água demineralizada.

A Figura 5.15 mostra um desses ensaios em estägios em superficie serrada, em carregamento crescente e decrescente, de onde se observa que dois estágios ã mesma tensão normal apresentam o mesmo valor de resistência, apesar de diferentes desloca mentos. Tal fato revela que as superfícies do espécime do en saio não sofreram praticamente nenhum dano; considera-se o peque no deslocamento às tensões mais altas como o fator responsável por isto.

A fim de comparar os ensaios em estágios e os continuos, e a dependência nos resultados, foram feitos dois ensaios, um de cada tipo, num mesmo corpo de prova, conforme mostra a Figura 5.16 . Pode-se notar que a resistência inicial ao escorregamento em ambos é a mesma, e que ao final do ensaio em estágios, reali zado após o contínuo, a resistência final, sob mesma tensão nọ mal é muito ligeiramente inferior. Acredita-se que a pequena diferença pode ser atribuida a um polimento natural experimentado pela superfície, com o deslocamento acumulado. Por outro la do, o ensaio contínuo apresentou valôres " residuais " suavemente crescentes com o deslocamento, pelo fato de ter apresentado um pequeno dano da superfície, do tipo milonitização.

Essa mesma diferença tambēm é ilustrada na Figura 5.17, 


$$
5.10
$$

pelas curvas de dois ensaios contínuos realizados em mesmo corpo de prova, de superfícies serradas, notando-se que o realizado em segundo lugar apresenta uma resistência algo inferior, e atri buida ao mesmo motivo.

Ensaios em estägios tambẻm foram realizados sobre super fícies polidas, conforme ilistrado na Figura 5.17, iniciando-os com a tensão normal mais baixa ou com a mais alta. o que iniciou com a tensão normal mais alta apresentou boa concordância com os valôres mínimos dos ensaios da superfície serrada.

Os resultados dos ensaios acima são apresentados no grâ fico de resistência da Figura 5.18 . Os ensaios em superfícies serradas apresentam-se com alguma dispersão, mas que é restrita a uma faixa estreita no grāfico. Os valôres ao deslocamento máxi mo são de ordem de $2 \circ$ a $3 \%$ maiores que os valôres iniciais, deví do à milonitização ao longo da superfície. Por outro lado, os resultados dos ensaios de superfícies polidas foram extremamente regulares, localizando-se com boa aproximação ao longo de uma re ta; os valôres ao deslocamento máximo representam ângulos de cêrca de 0,5 \% maiores que os correspondentes aos valôres ini ciais.

Os resultados acima refletem o fato de que as superfí cies serradas apresentam uma maior rugosidade das superfícies, o que causa o aumento da resistência ao atrito com relação às su perfícies polidas. A dispersão dos resultados é atribuida ao fato fato de as irregularidades serem provocadas pelo corte de serra e de serem diferentes de espécimen para espēcimen. A maior regularidade das superfícies polidas permitiu a boa regula ridade dos resultados, observada tanto paraensaios contínuos como em estágios.

Em todos os ensaios acima, e dentro dos limites de va riação utilizados, constatou-se que a velocidade de deslocamento é um fator irrelevante para a determinação da resistência ao es corregamento de superficies rochosas.

Basalto Compacto - Foi realizado apenas um ensaio em 
5.11

amostra de basalto, à tensão normal de $1,5 \mathrm{~kg} / \mathrm{cm}^{2}$; o ensaio foi realizado com corpo de prova submerso em āgua demineralizada, e constituido por uma superfície polida e uma serrada, por não se ter conseguido duas superfícies polidas perfeitamente pla nas para produzir um contacto por tôda a ärea da superfície.

o resultado do ensaio é apresentado na Figura 5.19 ,por meio de curva de resistência ao cisalhamento vs. deslocamento, denotando ter ocorrido o fenômeno conhecido por " STICK-SLIP ", ou seja, de escorregamento intermitente; assim o gráfico tem forma escalonada.

Para melhor visualização, foram traçadas as curvas cor respondentes aos pontos em que ocorre o escorregamento ( $\left.\tau_{a}\right)$ e aos pontos em que o escorregamento cessa, iniciando-se outra fase de aumento de tensões cisalhantes $\left(\sigma_{b}\right)$, mostrando que as fases de escorregamento ocorrem a intervalos mais ou menos regulares, tendo uma relação com a magnitude da queda $\left(\boldsymbol{\tau}_{\mathrm{a}}-\boldsymbol{\tau}_{\mathrm{b}}\right)$ da resistência ao cisalhamento. Essa relação ē mostrada no pequeno gráfico da Figura 5.19, onde tambēm constam os valôres do coeficiente de atrito calculados para alguns pontos notāveis da cur va, que variam de 25 o a cêrca de 29,5\%, correspondentemente aos pontos em que se dá o escorregamento.

Esses dados confirmam as pesquisas de Patton ( 1966a) e Coulson ( 1970 ) que encontraram coeficientes de atrito algo maiores para os calcáreos, incluindo o " Bedford ", com relação a vārios outros tipos litológicos, dos quais o basalto também fa zia parte.

5.7 - Ensaios Adicionais para Investigação da Influência Teor de Umidade, Velocidade de Deformação, e da Confiabi lidade dos Resultados

Conforme anteriormente mencionado, foram realizados vạ rios ensaios adicionais relacionados na Tabela 1.2 , para a apre 


\subsection{2}

ciação da influência dos fatôres acima enumerados. Embora estejam sendo designados por ensaios adicionais, os ensaios foram na realidade preliminares, ou concomitantes aos ensaios da pro gramação principal, sendo apenas algumas vêzes adicionais no sen tido de complementares.

Os ensaios para apreciação da influência do teor da umidade foram executados no solo " Goose Lake Flour ", para tensão normal de $1 \mathrm{Kg} / \mathrm{cm}^{2}$, e seus resultados são apresentados na Figura 5.20. Os teores de umidade variam de $24,4 \%$ a $36 \%$ fornecendo, progressivamente, resistência mais baixas. Como em todos os outros ensaios, os teores de umidade inicial e final foram determi nados; notou-se, para essa série de ensaios, que quanto maior o teor de umidade inicial, maior será sua diferença com o final, como mostra o pequeno gráfico da Figura 5,20, aproximando-se todos de um teor de umidade final de cêrca de 23\%

Foi em parte devido a êsses ensaios que decidiu-se efe tuar os ensaios da programação principal com um teor de umidade padrão, a fim de permitir comparações. Considerando-se, ainda,que o teor de umidade só tem significado quando comparado com os teores de umidade correspondentes aos limites liquido e plāstico, estabeleceu-se realizar os ensaios com a condição inicial, ao limite de liquidiz.

A verifícação da influência da variação da velocidade de deslocamento, ou de cisalhamento, na resistência constituiu-se em preocupação constante em todos os ensaios aqui apresentados. Dessa forma, em muitos dos ensaios, a velocidade foi mudada duran te o decorrer do próprio ensaio, para comparações. Notou-se, de modo geral, que a resistência cresce ligeiramente com o aumento da velocidade, e vice-versa, em consonância com a sintese feita por Lambe ( 1969 ) de outras pesquisas. Ao fato, êle atribui co mo responsável a viscosidade no deslizamento entre as partículas embora cite que em outros solos pode ocorrer o inverso, devido à tixotropia.

No entanto, para a caracterização da velocidade da queda. de resistência após o pico, em ensaios de contactos solo-rocha, 


\subsection{3}

foi feita uma série de quatro ensaios em espécimes de contacto entre o solo " Goose Lake Flour " e o calcăreo ( serrado), utilizando o mesmo espécimen de rocha, e variando a velocidade de até 50 vezes. As resistências máximas não apresentaram praticamente nenhuma variação, mas a queda de resistência apōs o pico era mais rāpida quanto menor a velocidade utilizada. Essa relação está representada, tentativamente, no gráfico menor da Figura 5.21 .

Ainda com relação à velocidade de deslocamento, o en saio do contacto entre argila residual e calcāreo ( polido ) foi submetido a duas reversões além do primeiro deslocamento, com ve locidade cêrca de dez vezes maior, com razoável coincidência de resultados; como era lógico esperar, apenas a resistência máxima, que nesse caso, suspeita-se, representa uma tensão de aderência, sofreu grande redução do primeiro para os dois outros ensaios.

Foram tambēm feitos alguns ensaios duplicando outros, no simples intuito de verificar se os resultados são repetitivos, caso em que se poderia atribuir-lhes boa confiabilidade. Um dês ses ensaios jã foi referido na apresentação da Figura 5.7 , rela tivo ao contacto caolinita-calcáreo onde, apesar de terem sido utilizados exemplares diferentes da rocha, alcançaram-se resulta dos muito próximos. A repetição de um desses ensaios ( fäzendose a reversão manualmente, pois o equipamento usado para esse en saio não dispunha de engates especiais, e então ensaiando-se um segundo deslocamento, no sentido usual) tambēm confirmou a sua confiabilidade, e forneceu valôres " residuais " insignificantemente menores.

Por último foram realizados três ensaios, duplicando outros três, e a diferentes tensões normais, com coincidência de resultados, tendo-se concluido da excelente confiabilidade dos ensaios, e do comportamento homogêneo de diferentes corpos de prova do mesmo solo ("Goose Lake Flour").

\section{8 - Resumo dos Resultados}




\subsection{4}

Os resultados obtidos nos ensaios realizados e apresenta dos através das Figuras 5.1 e 5.22 são sumarizados na Tabela 5.1, por meio dos ângulos das envoltórias dos vārios gráficos de resistência ou, no caso dos ensaios comparativos feitos a uma única tensão normal, pelo ângulo obtido da relação $\tau / \sigma$ ( consi derando-se $\mathrm{c}=0$ ) . Em vista de que as inclinações das envoltó rias variam em função da tensão normal, são definidos dois ângulos para cada envoltória, mencionando-se em parênteses a faixa de tensões normais correspondentes.

Do exame da tabela torna-se evidente que, para um mesmo nível de tensões, o ângulo de atrito do contacto solo-rocha é me nor que para o solo propriamente dito, sendo menor para o contac to em que a superfície de rocha é polida do que quando a superfície é serrada. O contacto com a superfície de fratura natural, por seu turno, fornece resistência maior que o de superfície ser rada.

E também interessante comparar os resultados de ensaios de mesma classe, porém procedidos com solos diferentes. Pode-se notar que as resistências diminuem progressivamente, com o au mento da plasticidade dos solos.

Nota-se, tambēm, que o ângulo de atrito obtido ao deslocamento máximo dos ensaios em solo apresenta relativamente grande variação, denotando o comportamento variado dos solos na re dução da resistência apōs o pico. Particularmente, os solos mais selecionados na fração argilosa apresentam redução mais râ pida. Essa variação, outrossim, indica que os deslocamentos fó ram insuficientes para alcançar as resistências residuais ou aproximar-se muito delas, como o caso do solo " Goose Lake Flour" e a argila residual. No entanto, o ângulo de atrito ao deslocamento māximo dos contactos com rocha polida exibe pequena variação, indicando resultados mais constantes, tanto na progressão dentro de uma mesma classe de ensaios, como com o nível de tensões.

As observações acima levam à recomendação que os resultạ dos em termos de ângulos de atrito devam sempre ser apresenta dos com as correspondentes tensões normais. Outrossim, acredita 
se que demonstram a conveniência dos ensaios de amostras compostas formando contactos, quer seja para a obtenção da menor resis tência que possa existir no conjunto, quer seja para obter a re sistência residual de um solo a relativamente pequenos desloca mentos, em ensaios rápidos e de baixo custo, e com equipamento convencional em uso corrente nos laboratórios de Mecânica dos so los. Ademais, mediante o uso da " trajetória de tensões " aqui introduzida, poder-se-á estimar com razoável precisão o ângulo de atrito residual de uma argila com apenas um ensaio de contac to com rocha polida, ou mesmo, mais facilmente, por ensaio tí po sanduiche.

Os dados dos ensaios são tambēm resumidos nos desenhos das Figuras $6.8,6.9$, e 6.10 , em função dos seus limites de liquidez e do Indice de plasticidade respectivos. 


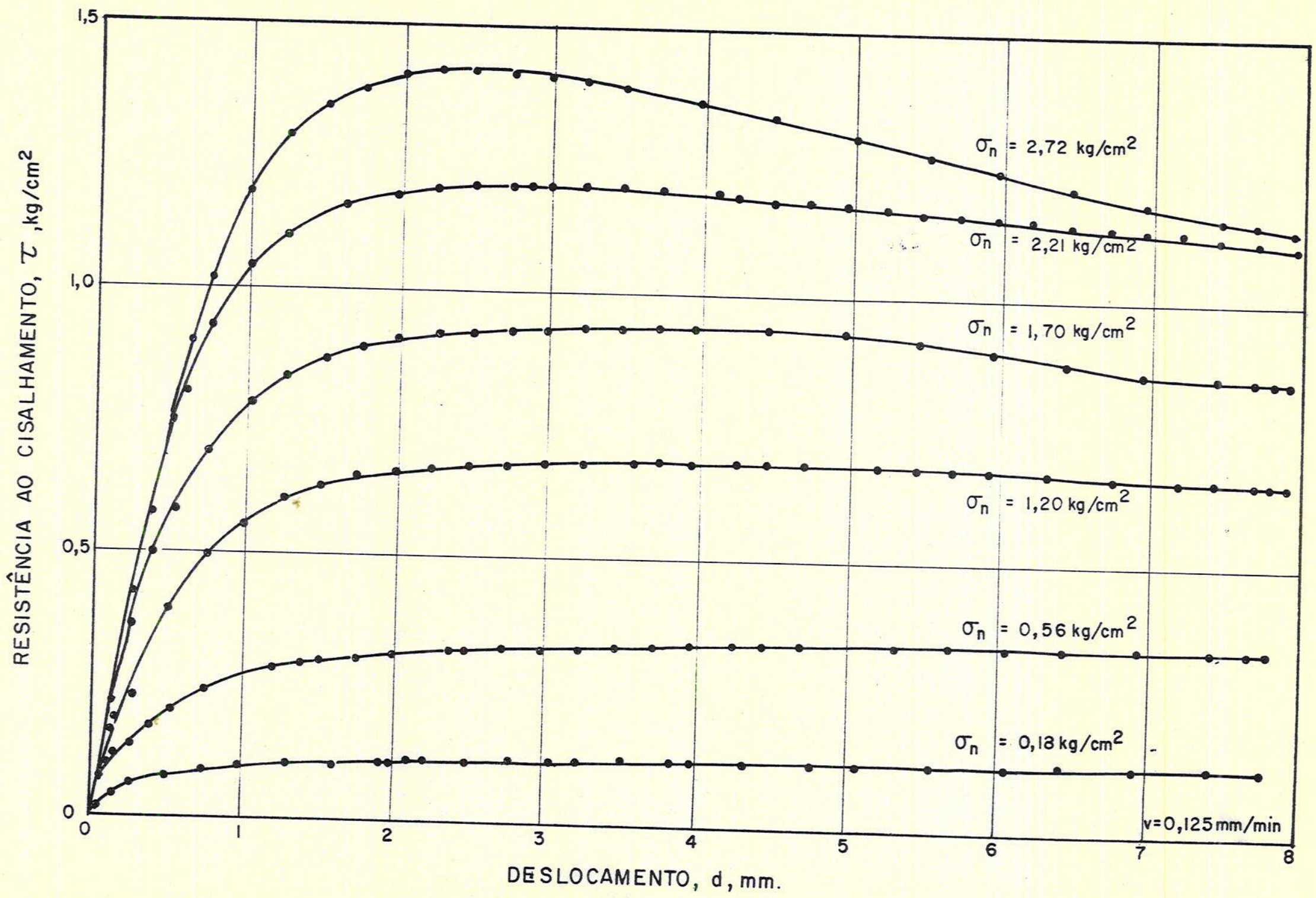

FIG. 5. I- CURVAS DE RESISTÊNCIA AO CISALHAMENTO VS. DESLOCAMENTO PARA O SOLO "GOOSE
LAKE FLOUR" 


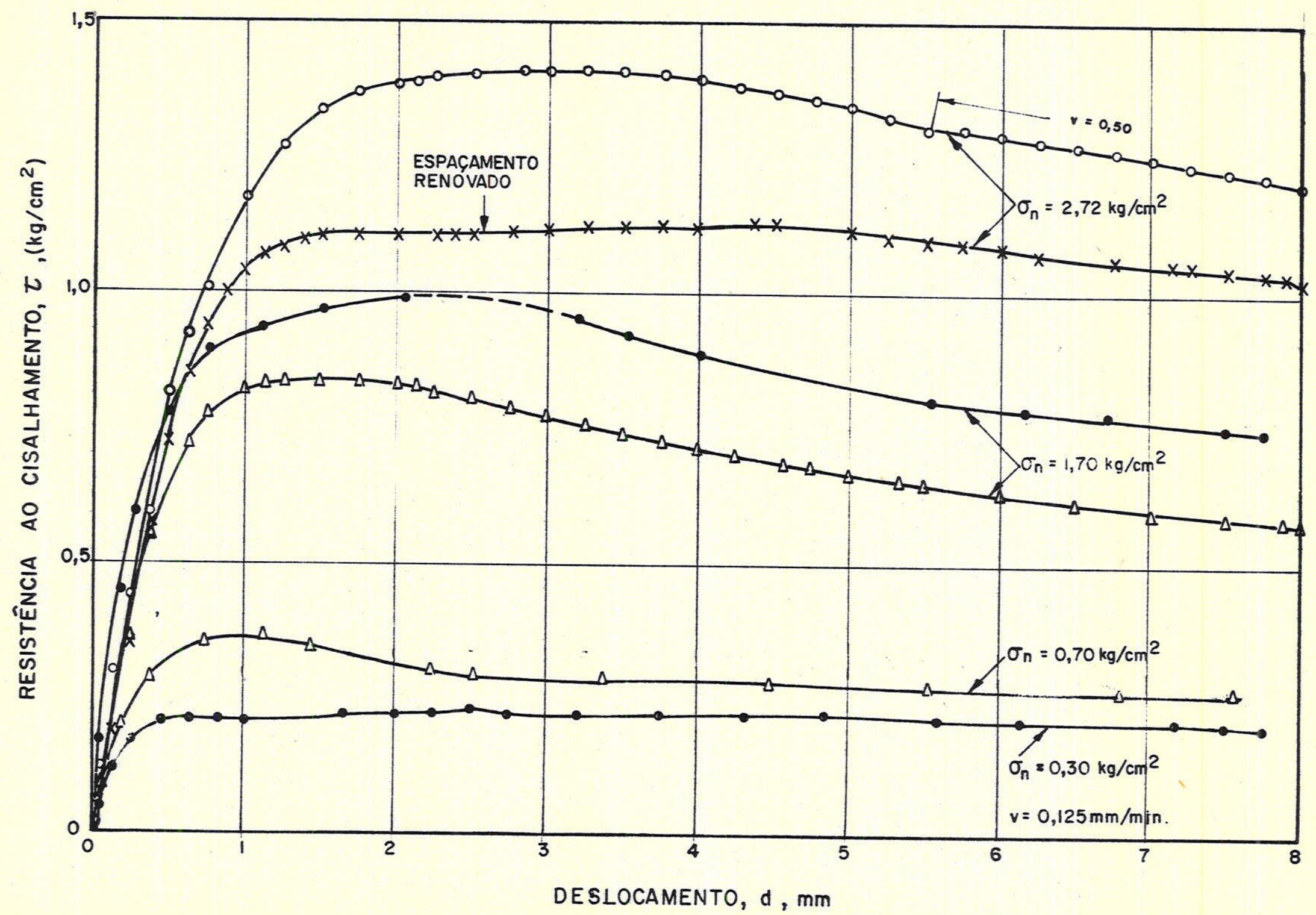

FIG. 5. 2- CURVAS DE RESISTÊNCIA AO CISALHAMENTO VS DESLOCAMENTOS DE CONTACTOS DE SOLO "GOOSE LAKE FLOUR"-CALCÁREO(SERRADO) 


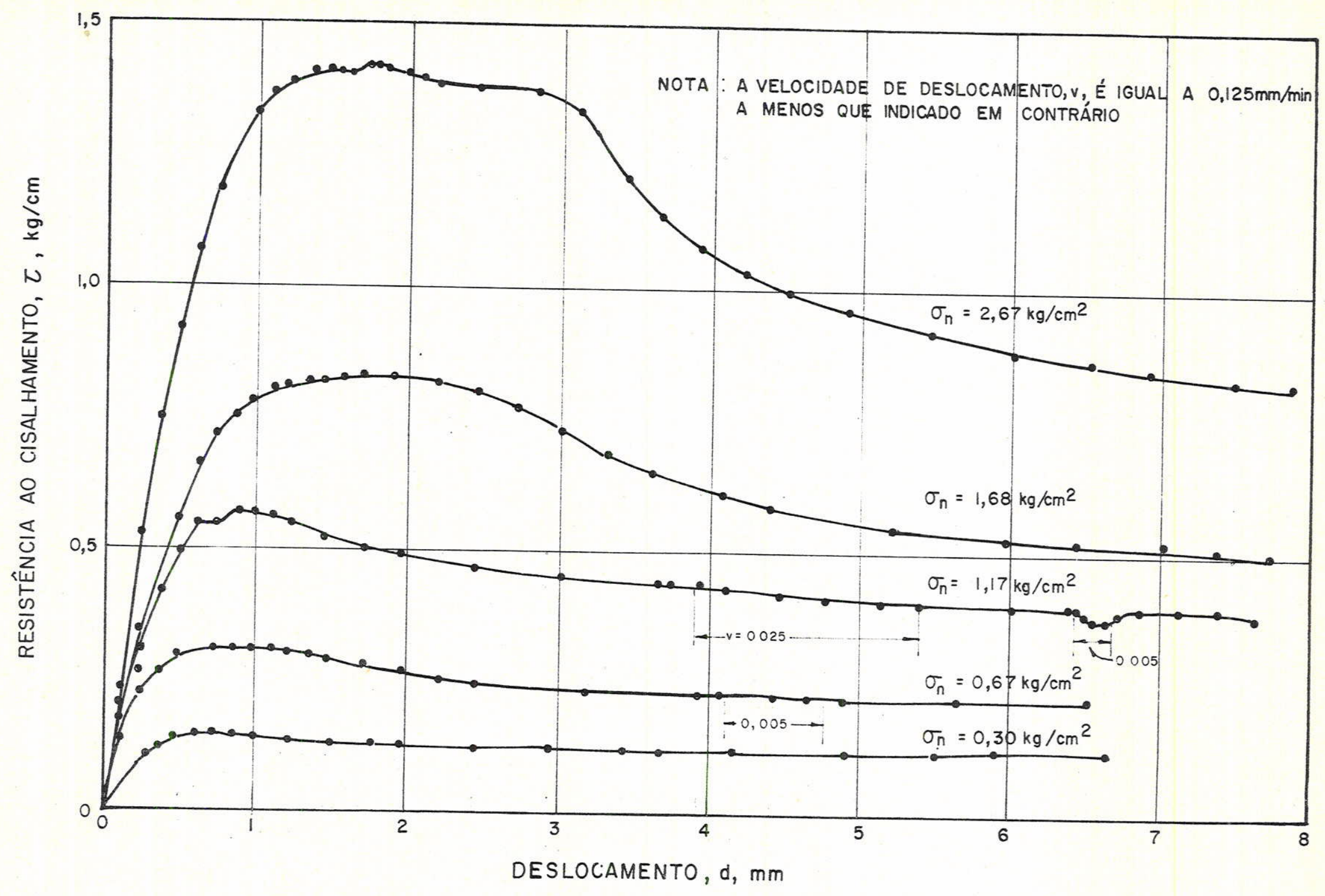
FIG. 5.3 - CURVAS DE RESISTÊNCIA AO CISALHAMENTO VS. DESLOCAMENTO DE CONTACTOS DE
SOLO "GOOSE LAKE FLOUR" - CALCÁREO (POLIDO) 


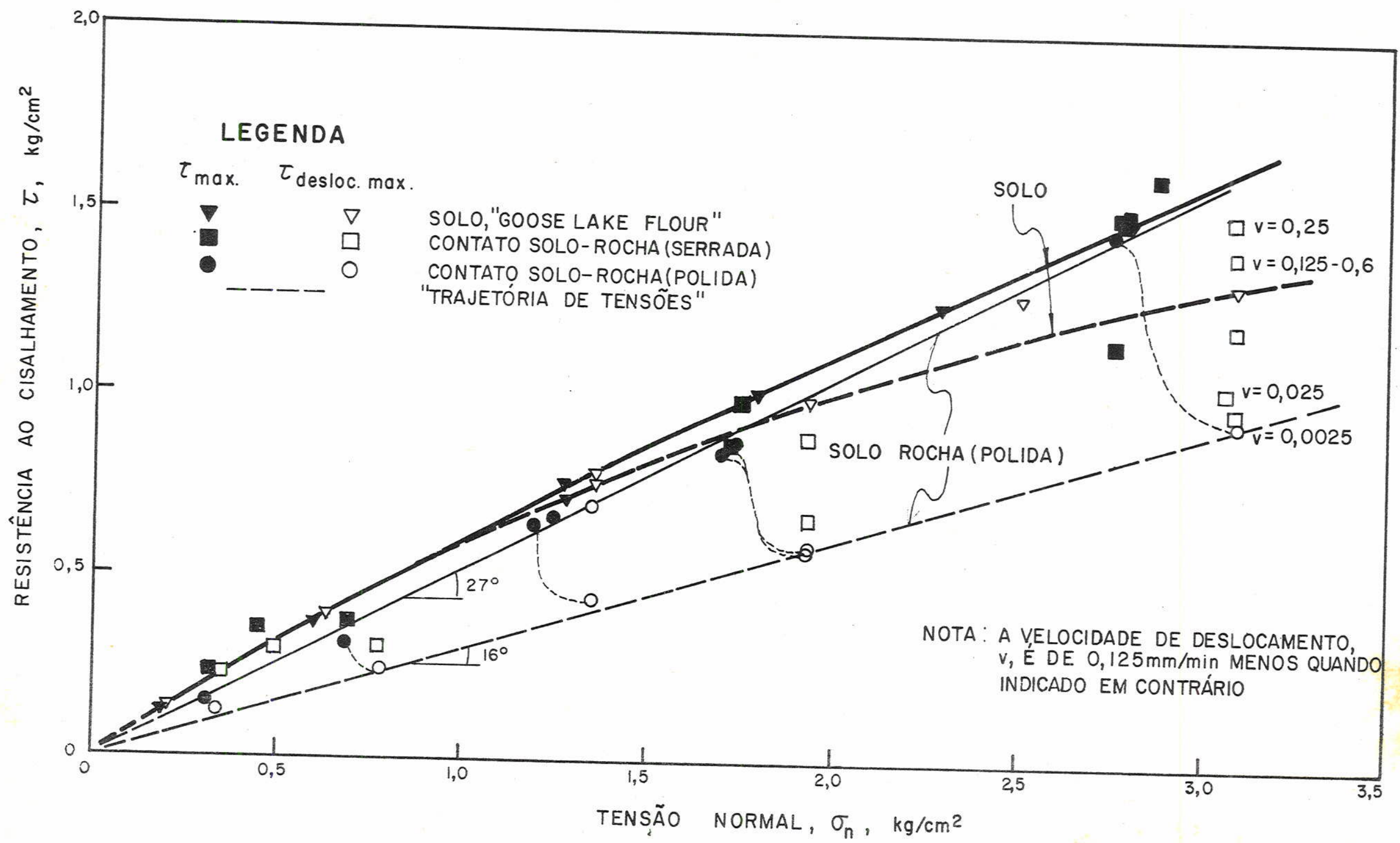

FIG. 5.4- GRÁFICO DE RESISTÊNCIA DO SOLO "GOOSE LAKE FLOUR" E SEUS CONTACTOS
COM O CALCÁREO 


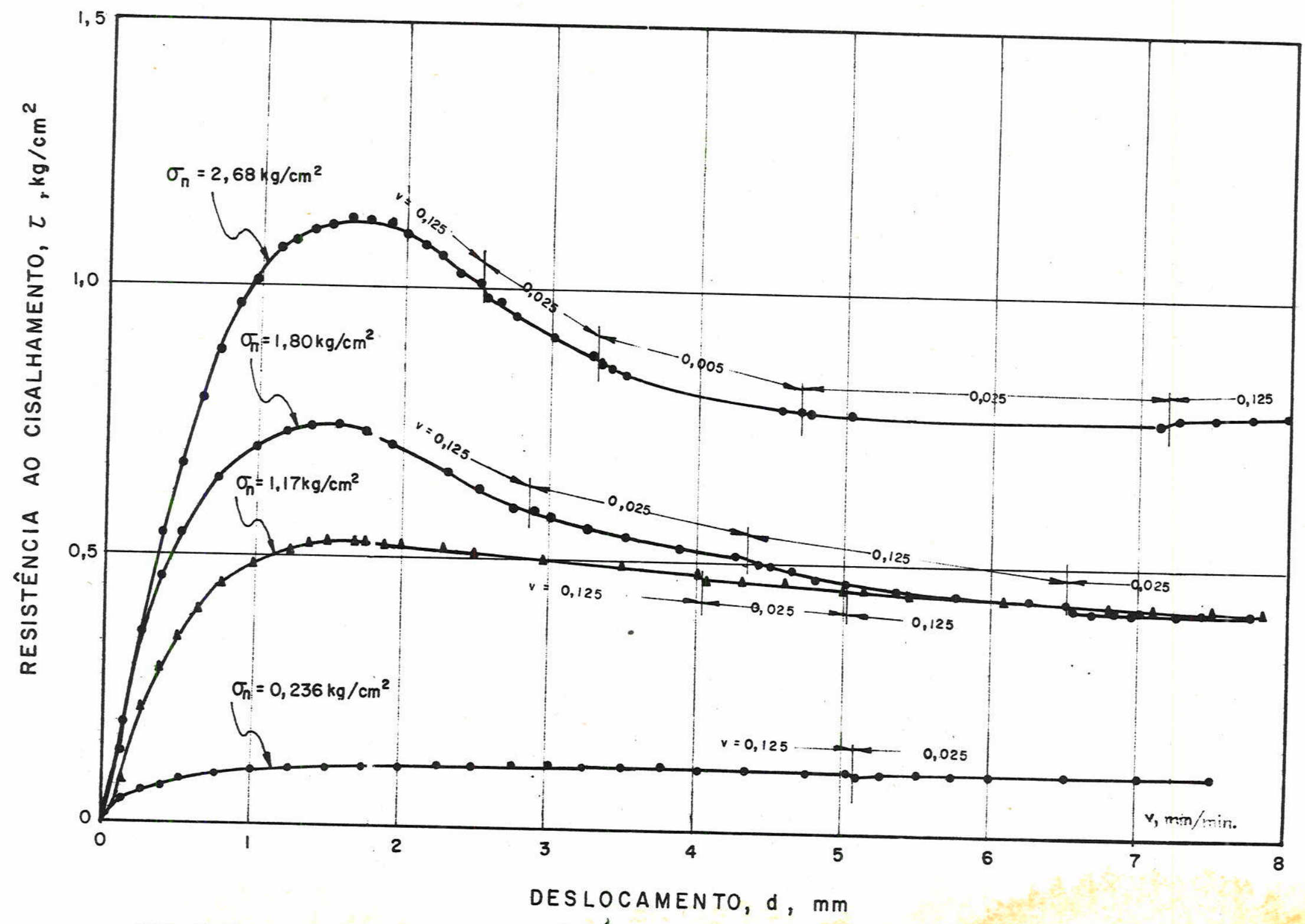

FIG. 5.5 - CURVAS DE RESISTÊNCIA AO CISALHAMENTO VS. DESLOCAMENTO PARA
A CAOLINITA. 


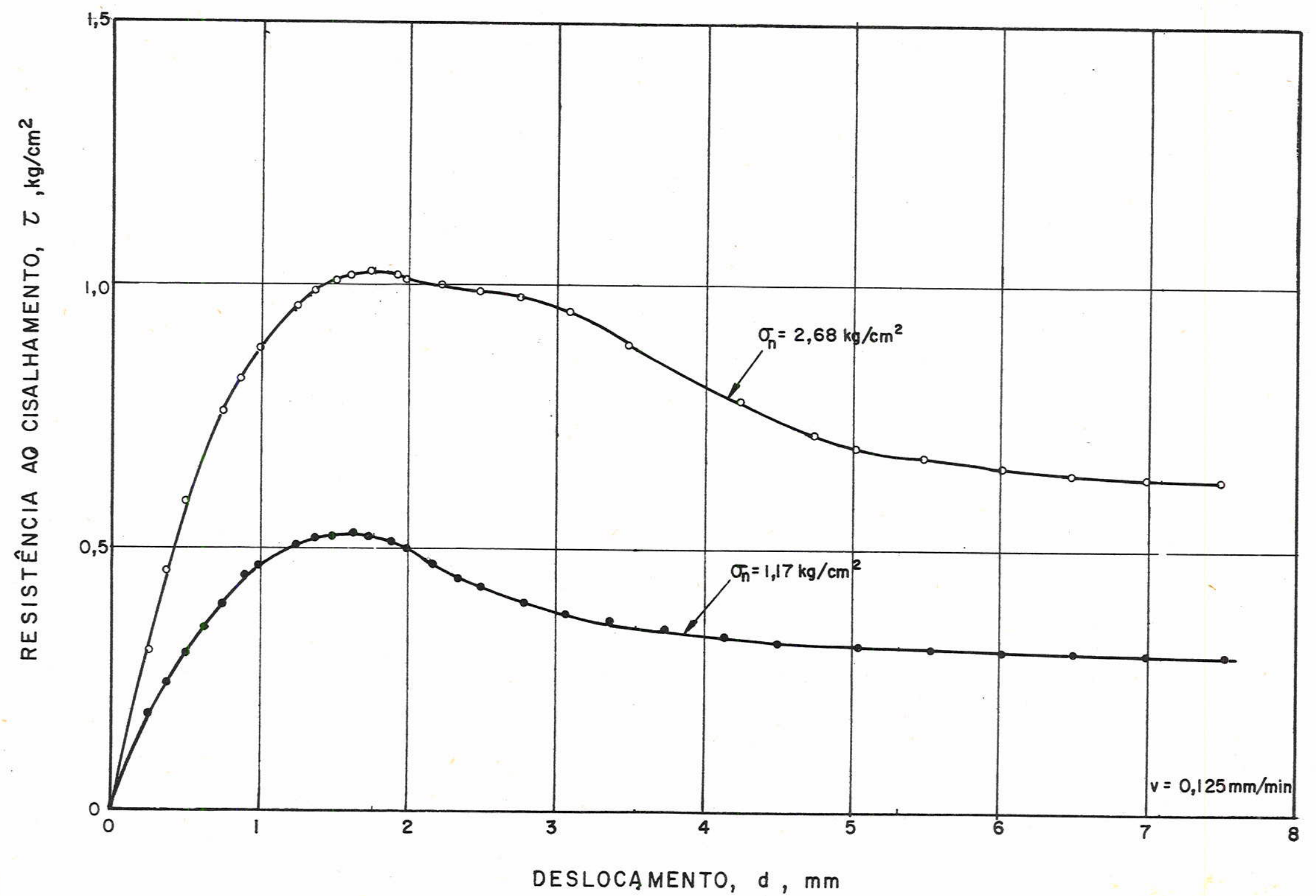

FIG. 5.6.- CURVAS DE RESISTÊNCIA AO CISALHAMENTO VS. DESLOCAMENTOS DE CONTACTOS CAOLINITA-CALCÁREO (SERRADO). 


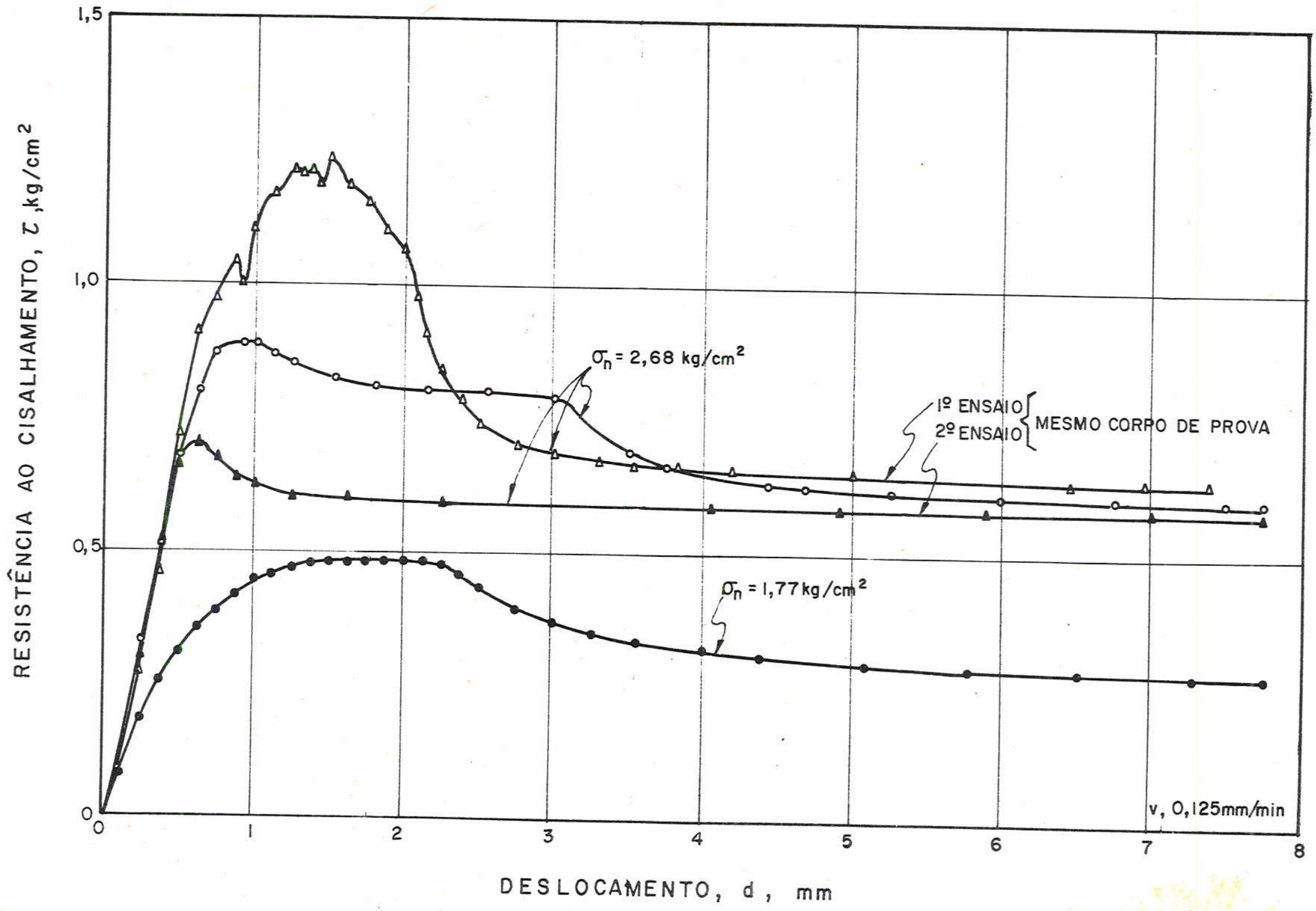

FIG. 5.7- CURVAS DE RESISTÊNCIA AO CISALHAMENTO VS. DESLOCAMENTOS DE CONTACTOS CAOLINITA - CALCÁREO (POLIDO). 


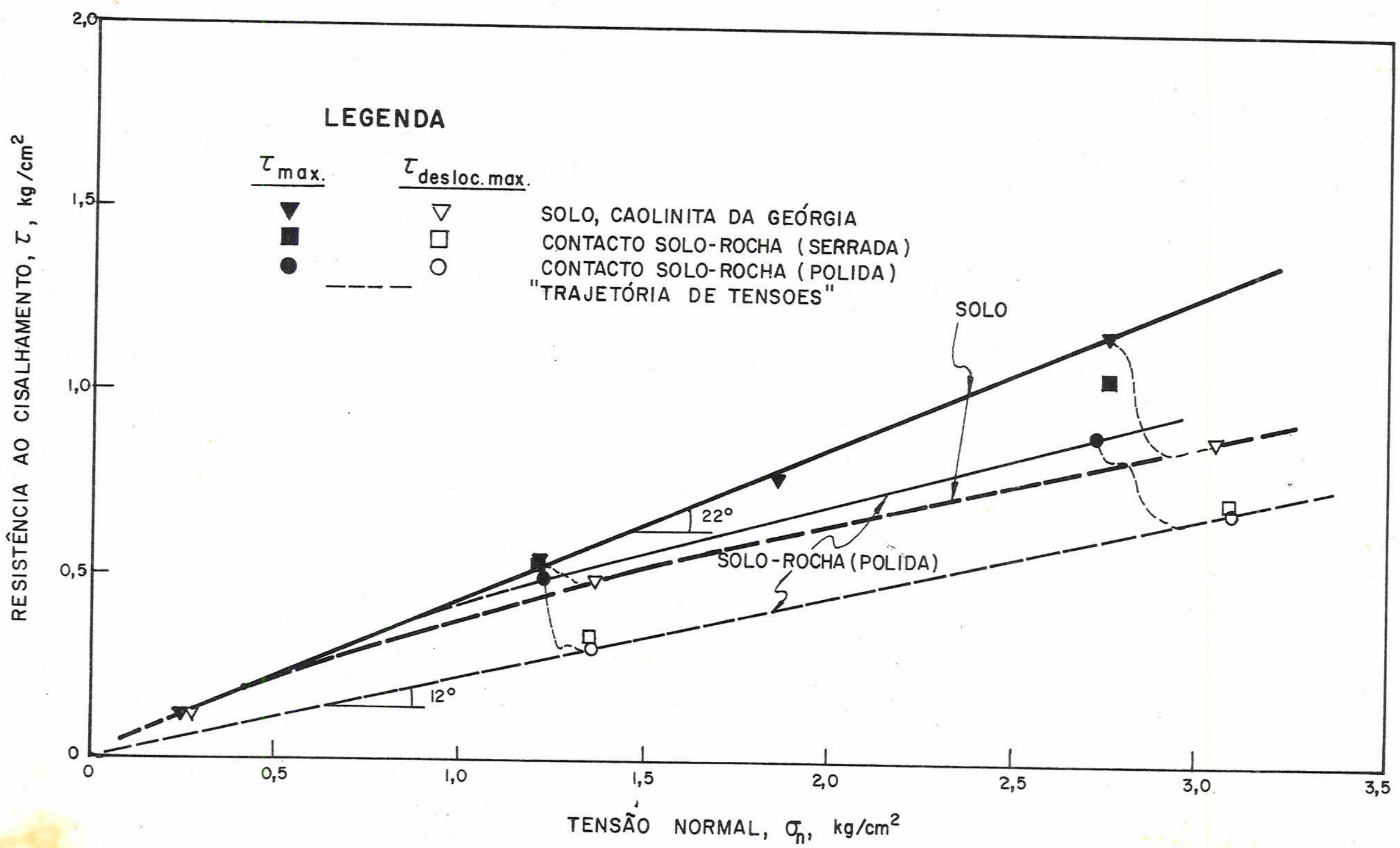

FIG.5.8-GRÁFICO DE RESISTÊNCIA DA CAOLITA E DE SEUS CONTACTOS COM O CALCÁREO 

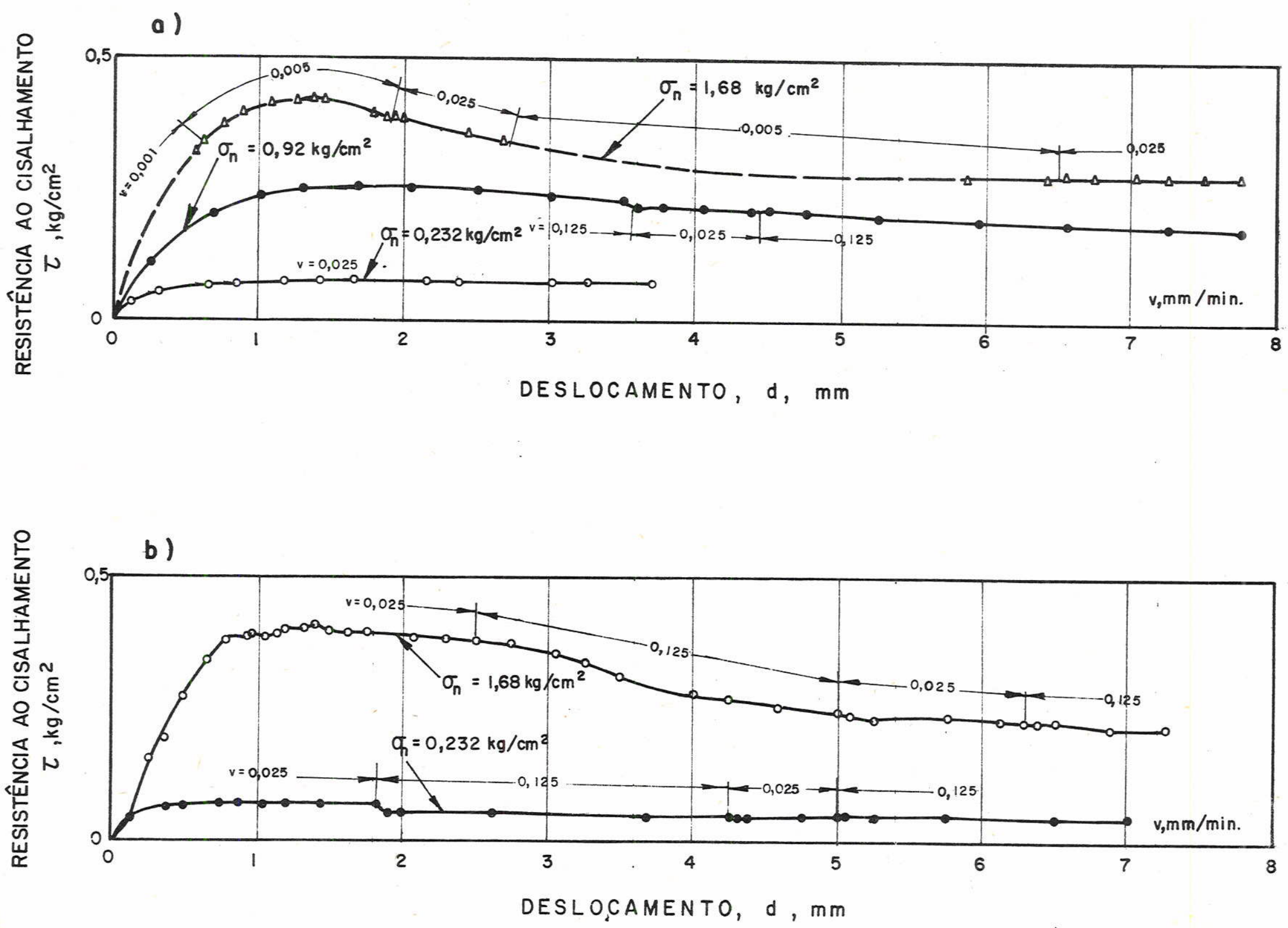

FIG. 5.9-CURVAS DE RESISTEANCIA AO CISALHAMENTO VS. DESLOCAMENTOS PARA a) ILITA E b) DE CONTACTO ILITA-CALCÁREO (POLIDO). 


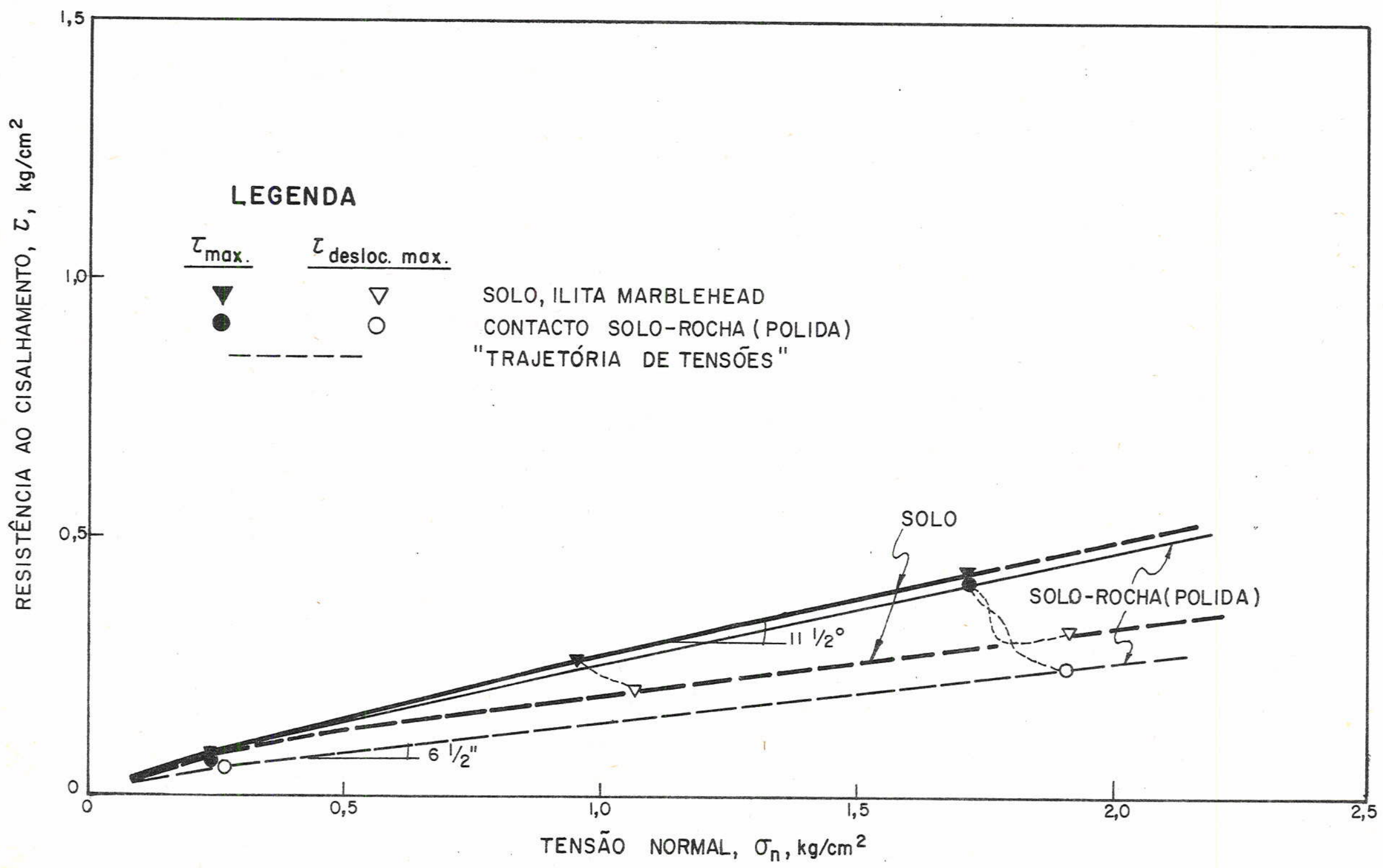

FIG. 5.10- GRÁFICO, DE RESISTÊNCIA DA ILITA E DE SEUS CONTATOS COM 
VELOCIDADES DE DESLOCAMENTO UTILIZADAS $(\mathrm{mm} / \mathrm{min})$
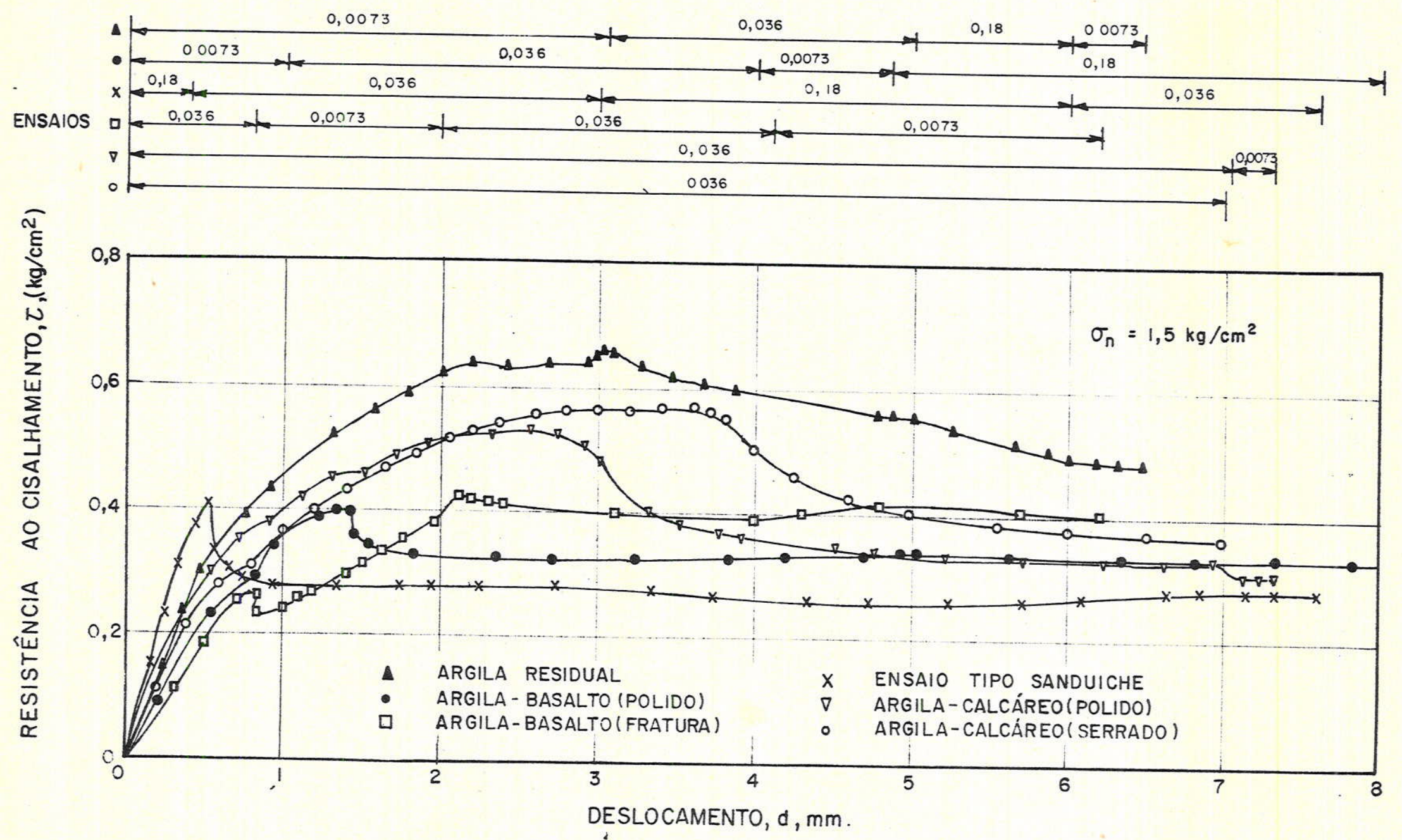

FIG.- 5.I1. CURVAS DE RESISTÊNCIA AO CISALHAMENTO VS. DESLOCAMENTOS PARA ARGILA RESIDUAL E EM CONTACTOS DIVERSOS COM BASALTO E CALCÁREO 


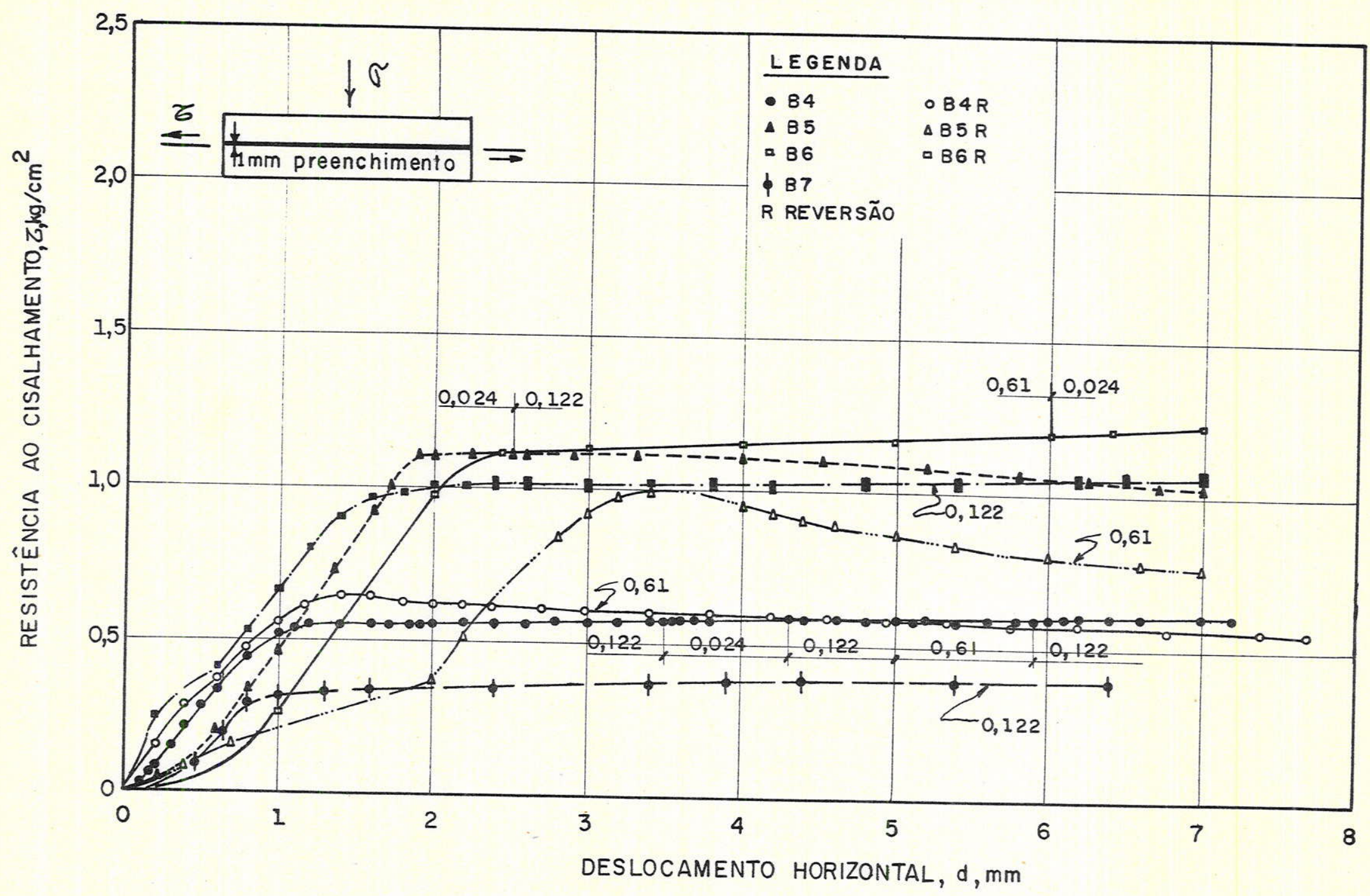

FIG. 5.12 CURVAS DE RESISTÊNCIA AO CISÁLHAMENTO/DESLOCAMENTO HORIZONTAL BASALTO COM PREENCHIMENTO DE SILTE 


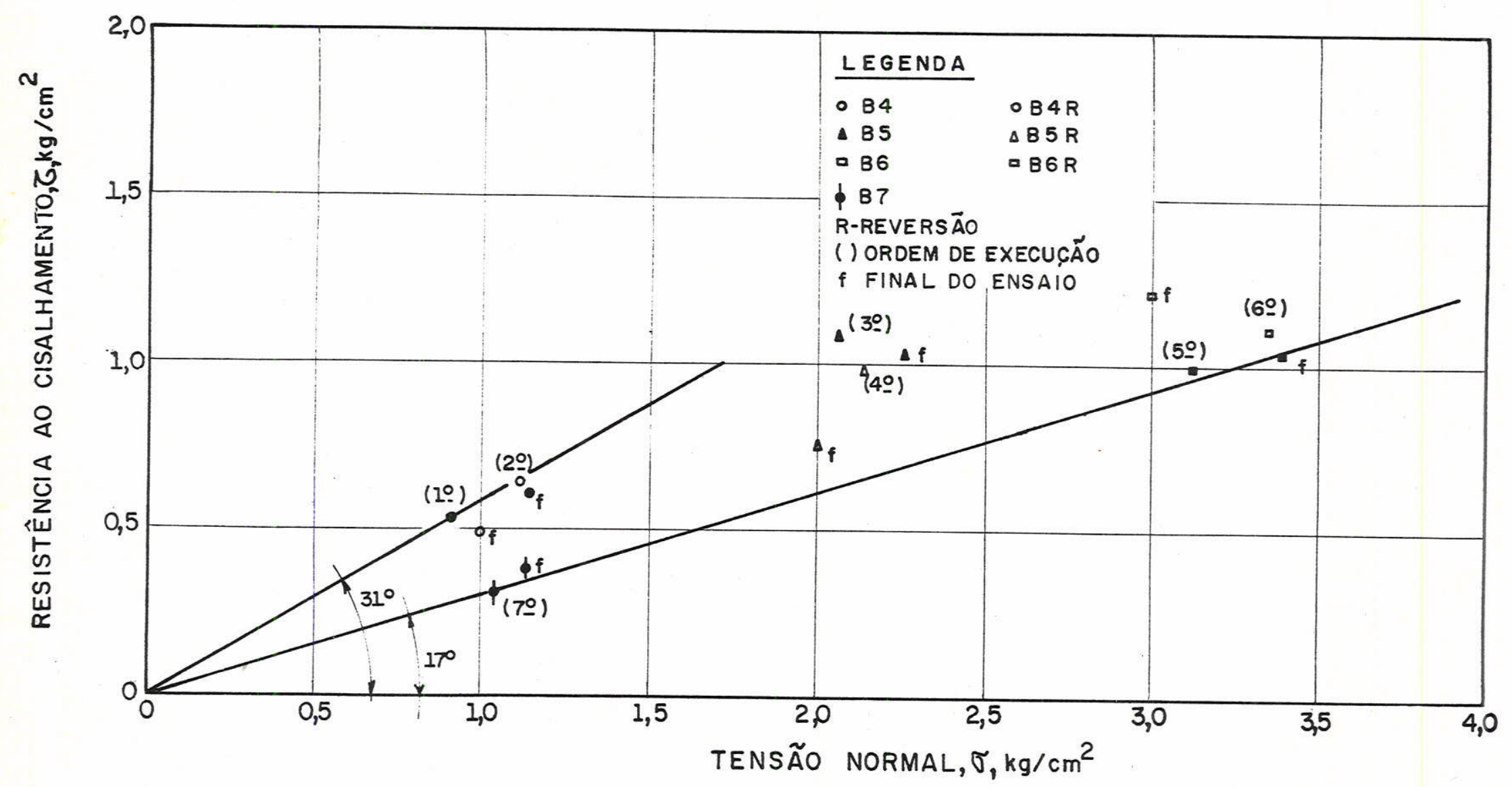

FIG. 5.13 GRÁFICO DE RESISTÊNCIA AO CISALHAMENTO EM FUNÇÃO DA TENSẢO NORMAL BASALTO COM PREENCHIMENTO DE SILTE 


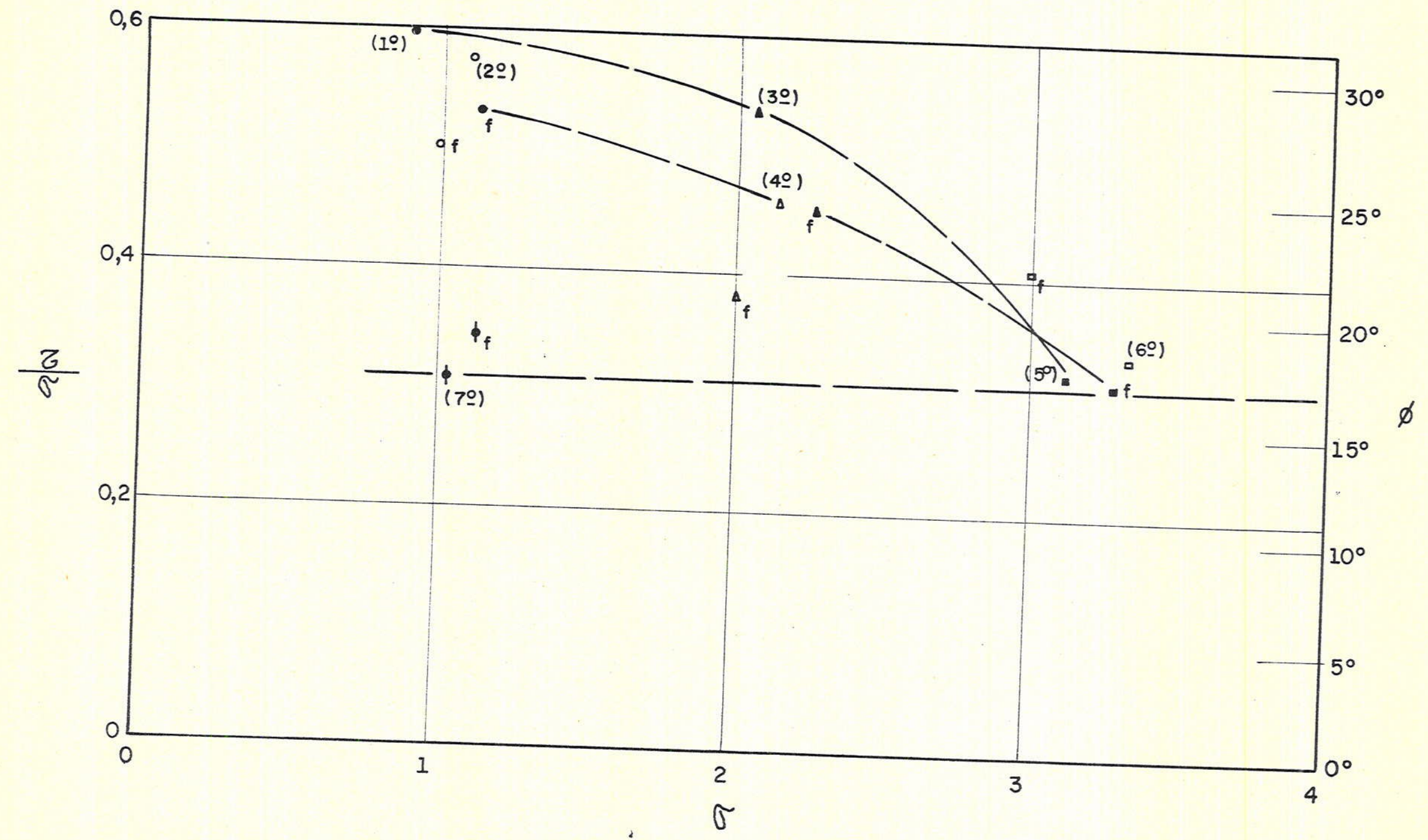

FIG. 5.14 VARIAÇÃO DA RELAÇẢO 乙/ $\sigma$ E DE $\emptyset$ EM FUNÇÃO DE $\widetilde{\sigma}$ E DO DESLOCAMENTO BASALTO COM PREENCHIMENTO DE SILTE 


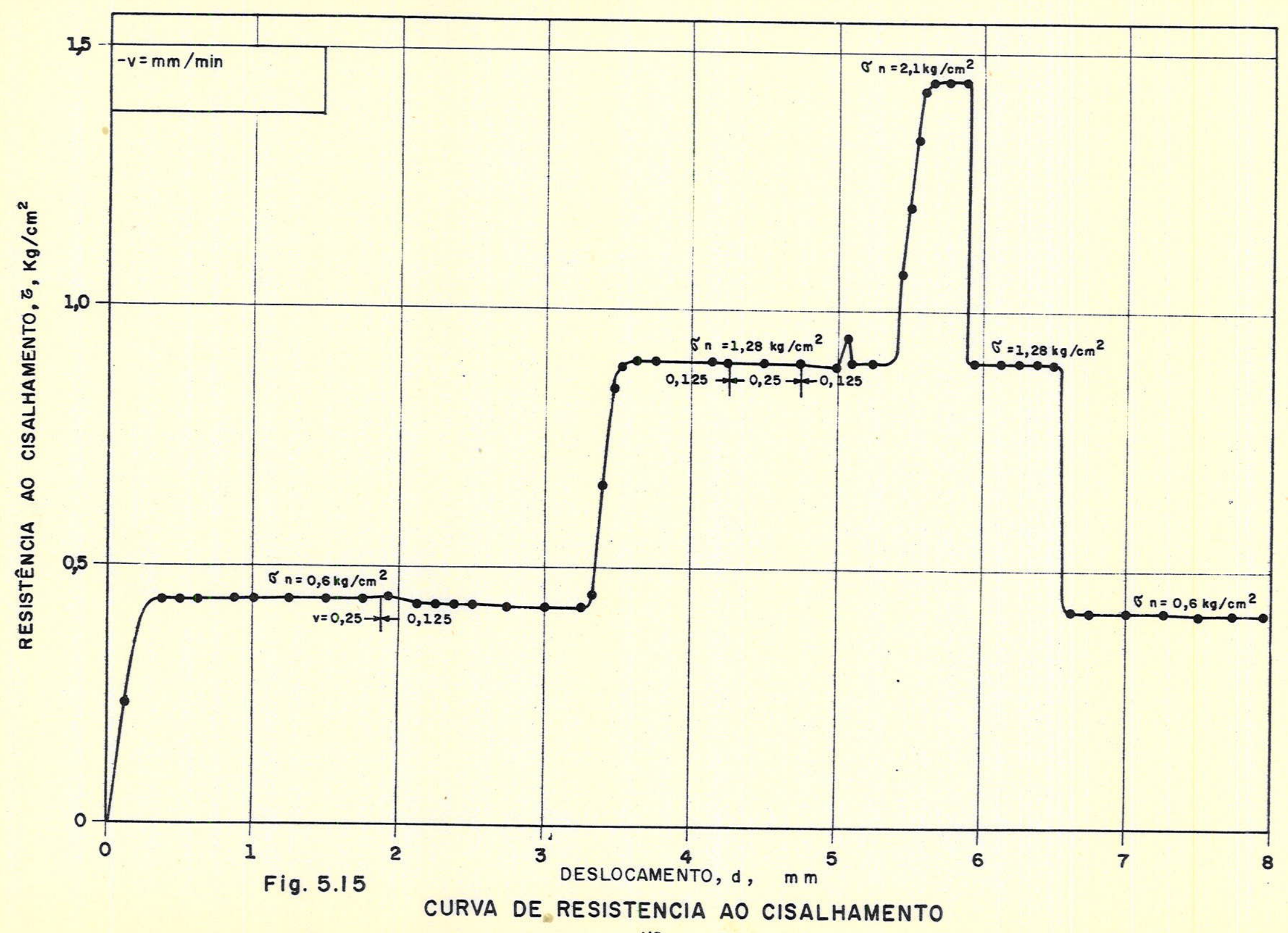

DESLOCAMENTO DE SUPERFÍCIES DE CALCÁREO (serrado), ENSAIOS EM ESTÁGIOS 


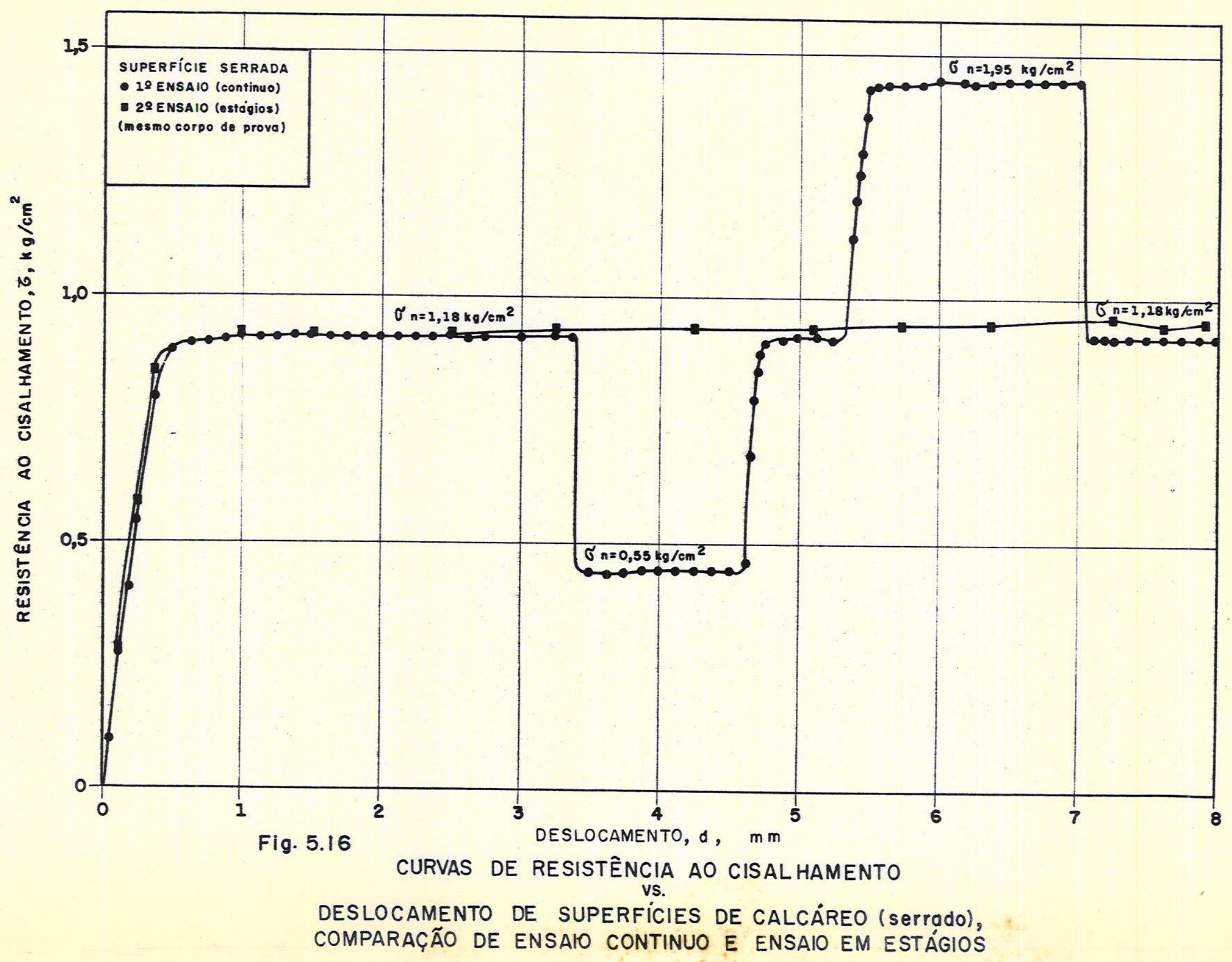




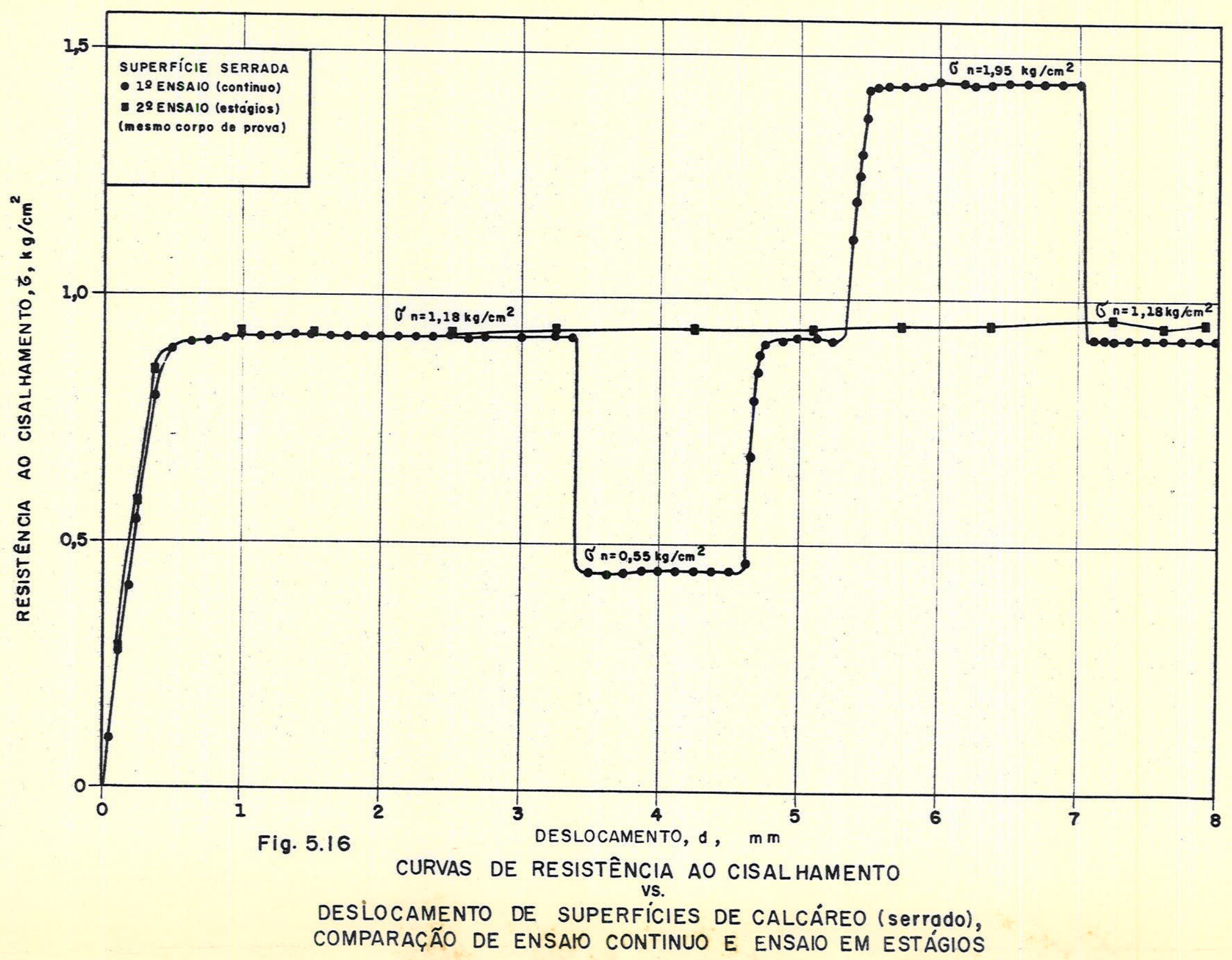




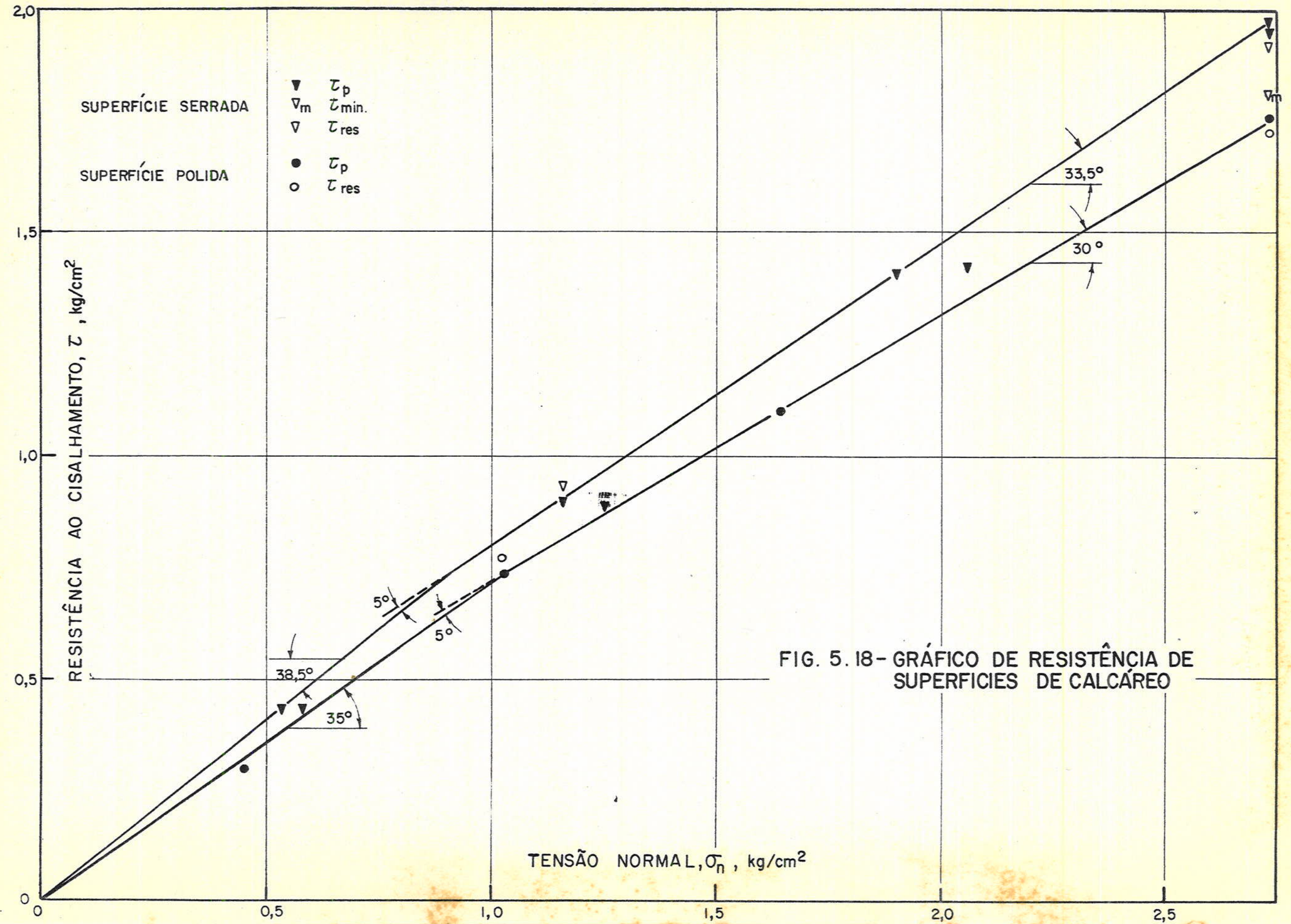




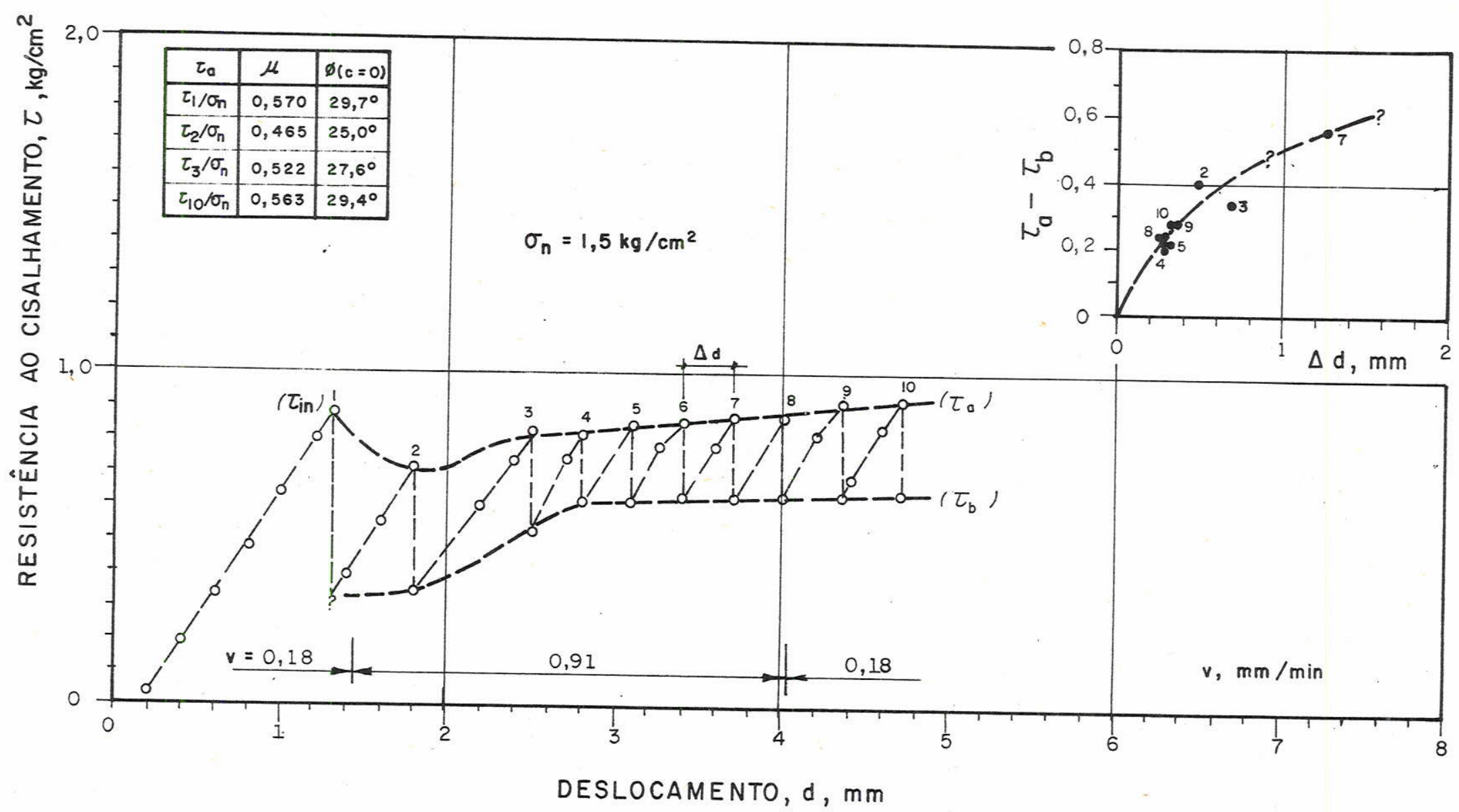

FIG. 5. 19- CURVA DE RESISTÊNCIA AO CISALHAMENTO VS. DESLOCAMENTO DE BASALTO (POLIDO/SERRADO) 


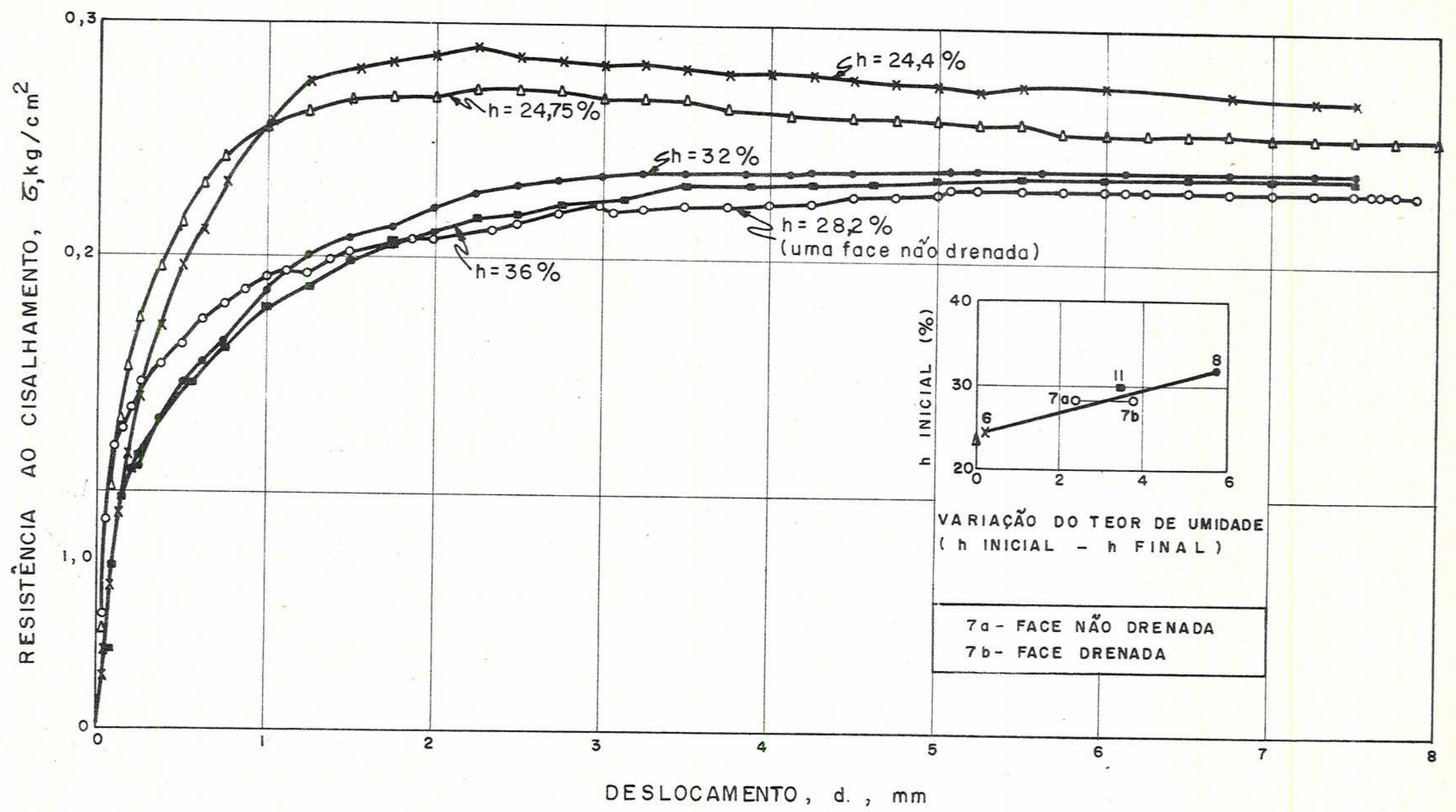

FIG. 5.20 - CURVAS DE RESISTÊNCIA AO CISALHAMENTO V.S. DESLOCAMENTO PARA O SOLO "GOOSE LAKE FLOUR" PARA DIFERENTES TEORES DE UMIDADE 


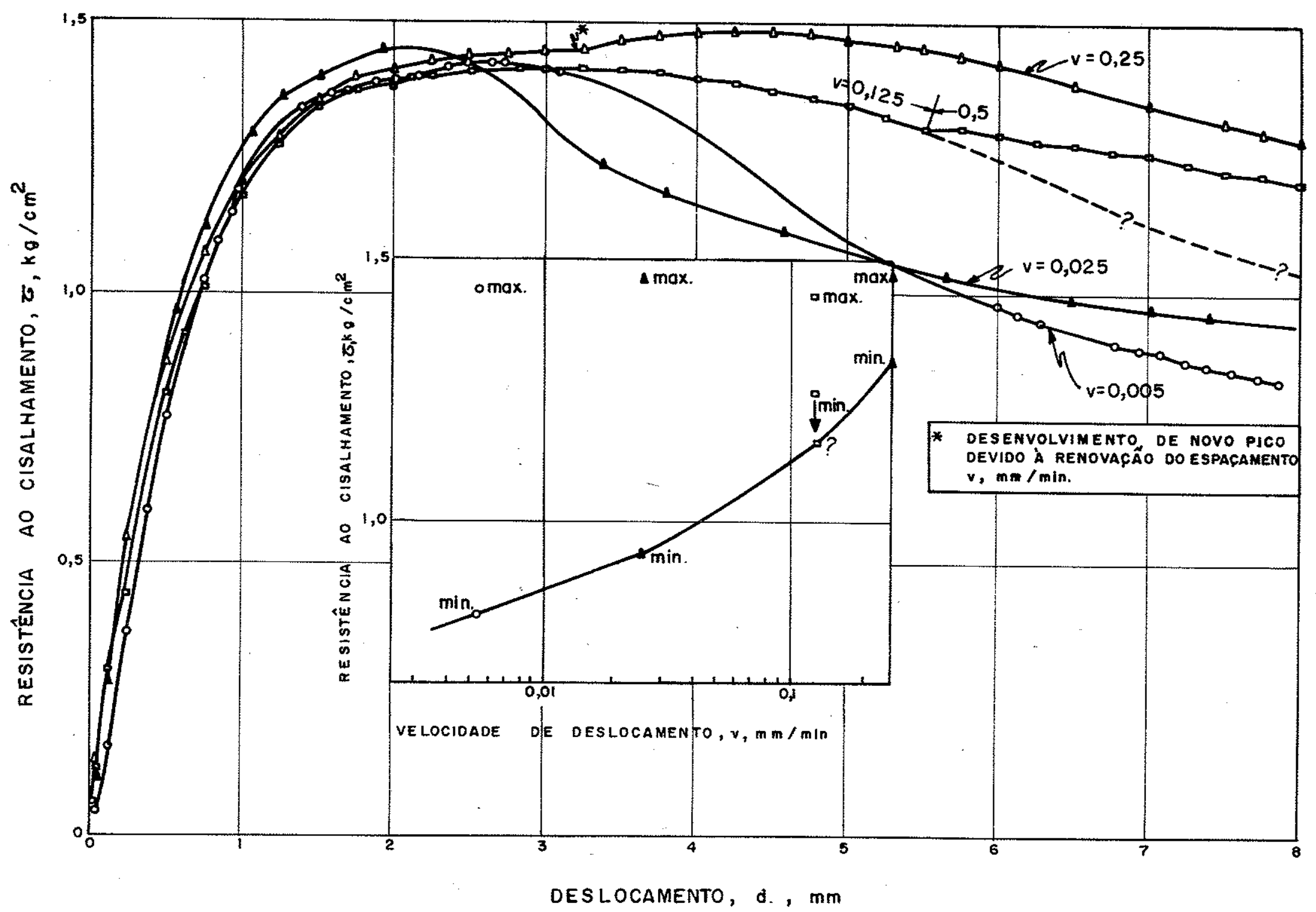

FIG. 5.21 - CURVAS DE RESISTÊNCIA AO CISALHAMENTO V.S. DESLOCAMENTO

PARA O CONTACTO "GOOSE LAKE FLOUR" - CALCAREO

(SERRADO) SOB VARIAS VELOCIDADES

DE DESLOCAMENTO 


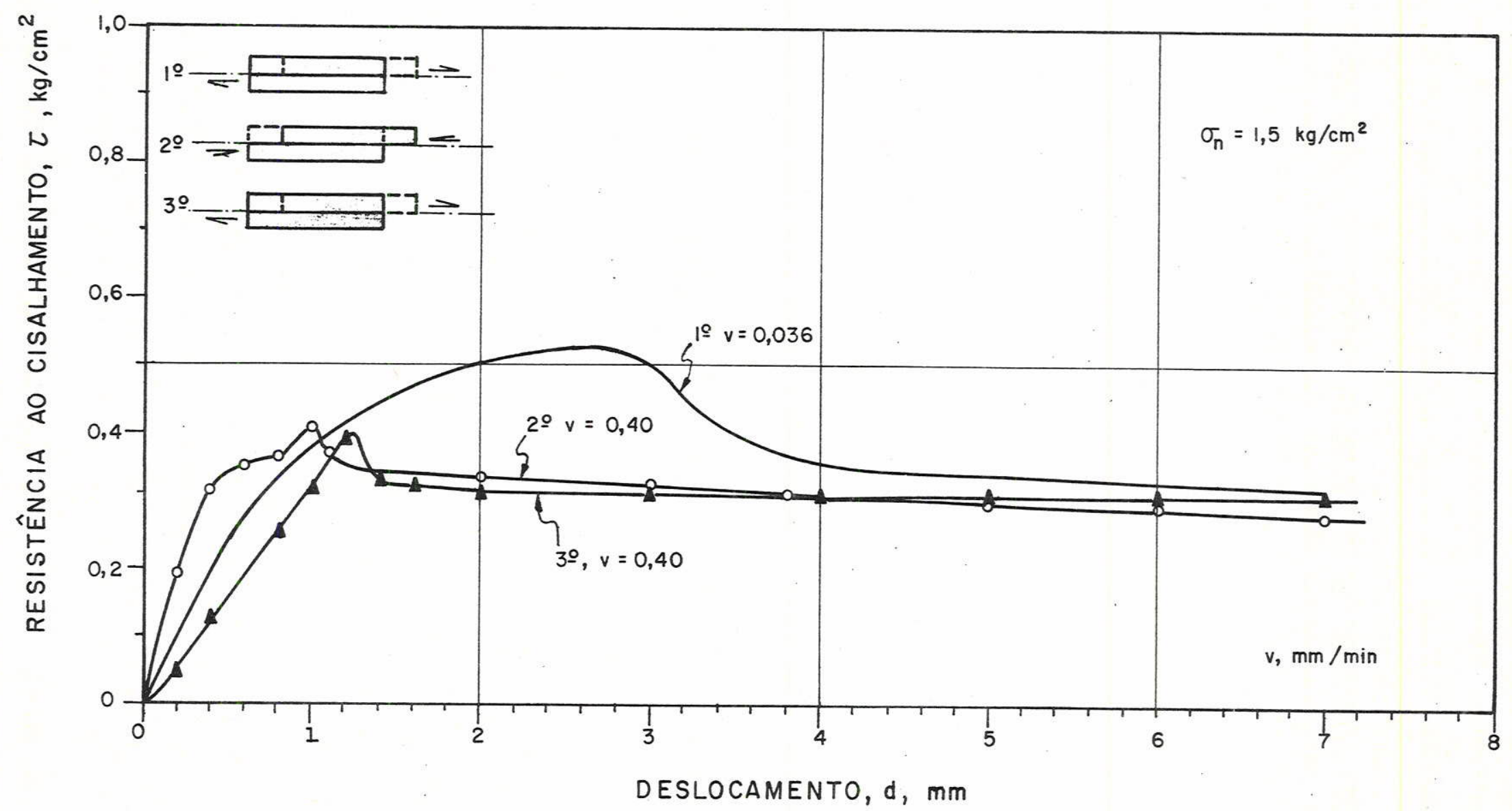

FIG.5.22 - CURVAS DE RESISTÉNCIA AO CISALHAMENTO VS. DESLOCAMENTO DO CONTACTO ARGILA RESIDUAL DE BASALTO - CALCÁREO (POLIDO) COM REVERSÕES E VARIAÇÂO DA VELOCIDADE DE DESLOCAMENTO. 


\begin{tabular}{|c|c|c|c|c|c|c|}
\hline \multirow{3}{*}{$\begin{array}{l}\text { MATERIAI } \\
\frac{\text { Notas }}{\varnothing \text { em graus }} \\
\text { ( ) nivel de tensão } \\
\text { * para c=0 } \\
\text { (s) - Sanduiche }\end{array}$} & \multirow{2}{*}{\multicolumn{2}{|c|}{$\begin{array}{l}\text { SOLO } \\
\text { APENAS }\end{array}$}} & \multicolumn{4}{|c|}{ CONTACTOS } \\
\hline & & & \multicolumn{2}{|l|}{ SERRADA } & \multicolumn{2}{|l|}{ POLIDA } \\
\hline & $\varnothing \operatorname{māx}$ & $\varnothing$ min. & $\varnothing$ máx. & $\begin{array}{l}\text { omin. } \\
\text { obt. }\end{array}$ & $\varnothing \max$ & $\varnothing \max _{o b t .}$ \\
\hline Calcāreo " Bedford " & - & - & $37-36,5$ & $38,5-35,5$ & 33 & 32,5 \\
\hline Basalto Compacto & - & - & - & - & $\begin{array}{l}29,7 \\
(1,5)\end{array}$ & $\begin{array}{l}25 \\
(1,5) \\
\end{array}$ \\
\hline "Goose Lake" / Calcāreo & $26-27$ & $34,5-22,5$ & $38-26$ & $33,5-17$ & $27,5-26$ & 2016 \\
\hline Caolinita / Calcāreo & $26-22,5$ & $25-16$ & $23,5-20,5$ & $14-13$ & $22-18$ & $13-12$ \\
\hline Ilita / Calcāreo & $18,5-14$ & $18(?)-9,5$ & - & - & $16,5-13,5$ & $11-7$ \\
\hline Argila Residual / Basalt & to $\begin{array}{l}23,8 * \\
(1,5)\end{array}$ & $\begin{array}{r}19,5 * \\
(1,5)\end{array}$ & $\begin{array}{c}\text { Fratura } \\
15 * \\
(1,5)\end{array}$ & $\begin{array}{c}\text { Fratura } \\
14,5 * \\
(1,5)\end{array}$ & (s) $\begin{array}{l}15 * \\
15,5 * \\
(1,5)\end{array}$ & 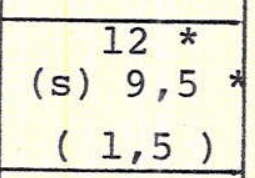 \\
\hline Argila Residual / Calcāreo & - & - & - & - & $\begin{array}{l}19,2 * \\
(1,5)\end{array}$ & $\begin{array}{l}1.5,5 \\
(1,5) \\
\end{array}$ \\
\hline $\begin{array}{c}\text { Silte de Preenchimento } \\
\text { Basalto }\end{array}$ & - & - & - & - & s) $(1,0)$ & $(\mathrm{s})(1,0)$ \\
\hline
\end{tabular}

Tabela 5.1 - Ângulos $\varnothing \max$ e $\varnothing$ min obtido para as Rochas, Solos, e Contactos SoloRocha Ensaiados. 
6. DISCUSSÃO DE OUTROS FATORRES RELACIONADOS A $\cdot$ RESISTENNCIA AO CISALHAMENTO

\section{1 - Atrito entre Minerais}

Julga-se o estudo do atrito entre minerais como băsico para uma boa compreensão do atrito de superfícies lisas de rocha, por serem as mesmas constituidas de vários minerais. Não existe atē o momento nenhum estudo tentando relacionar o coeficiente deatrito de superfícies lisas de rocha com os atritos dos diversos minerais que a constituem, ponderadamente, em função da porcentagem de ocorrência de cada mineral. Isso pode ser devido ao fato de que o atrito entre minerais não è ainda perfeitamente conhecido. As gamas de variação dos coeficientes de atrito para cada mineral são grandes, algumas vezes, e são poucos os càsos de poder-se atribuir a uma espécie mineral um coeficiente bem de terminado. Por outro lado, a maioria das publicações sôbre o as sunto caracterizam insuficientemente as condições da superfície e da composição do material ensaiado, dificultando reinterpreta ções posteriores.

Apesar disso, pade-se coletar valiosos dados das publica ções de Lambe e Whitman ( 1969 ) e Coulson ( 1970), os quais re sumem as mais importantes investigações existentes sobre o atrito entre minerais, incluindo a de Horn e Deere ( 1962 ). Os dados nessas publicações são aparentemente dispersos, com exces são da influência da presença de água e da rugosidade. No entan to, Barton ( 1971 ) encontrou uma dependência do coeficiente de atrito à resistência à compressão das rochas. Como é sabido, há, 


\section{2}

por outro lado, excelente correlação entre a resistência à compressão e a dureza escleromētrica das rochas. Seguindo este raciocínio, procedeu-se à correlação entre o coeficiente de atri to de minerais com a sua dureza, utilizando-se dos dados forneci dos por aqueles autores citados, e apresentada no gräfico da Figura 6.1. Apresentam-se os minerais da escala de Mohs em or dem crescente de dureza relativa, bem como duas das várias escalas de dureza esclerométrica determinadas por vārios autores. Em primeiro lugar, nota-se claramente que a escala de dureza re lativa de Mohs tem uma função logarítmica com as escalas de dure za absoluta. Em segundo lugar, correlacionando a escala de dure za relativa com os coeficientes de atrito dos minerais ( ou suas respectivas gamas de variação), nota-se que para superfícies sê cas o coeficiente de atrito diminui com o aumento da dureza.

Como dureza, resistência à compressão, e mỏdulo de elasticidade são diretamente relacionados, o coeficiente de atrito deve estar necessariamente relacionado à deformabilidade das su perfícies minerais, resultando um coeficiente de atrito tanto maior quanto maior a deformabilidade e o entrosamento das irregu laridades de uma superfície na outra.

Deve, contudo, ser sublinhado que a êsse efeito devem ser superpostos os demais que intervêm no processo, como à irre gularidade, presença de āgua e composição mineräl.

\section{2 - Influência da Rugosidade no Atrito de Superfïcies de Ro- cha}

Existem muitos dados de coeficientes de atrito de descon tinuidades sob vārias condições de rugosidade na literatura, que são, entretanto, inaproveitáveis para a correlação respectiva, pois a rugosidade é apenas definida por têrmos qualitati vos como " liso ", " pouco rugoso ","muito rugoso ", etc,, ou então pela gênese do plano ensaiado, como" plano de acamamento ", "fratura ", etc. 
6.3

Constata-se, portanto, ser imperativa uma descrição precisa, quantitativa, da rugosidade. Na tentativa de estabele cer um critério para o que demais autores chamam de "1iso ", "rugoso ", etc, foi construido o desenho da Figura 6.2 que agrega as classificações esparças coletadas da bibliografia. Cô mo base para comparações foram represenrados no mesmo desenho os critérios usualmente adotados em Hidráulica, para rugosidade de tubulações de concreto, aço e madeira. Conclui-se que exis tem vārias escalas e critéiros de classificação de rugosidade, e que à mesma dimensão das irregularidades existem diferentes esca las, uma classificando-a de muito " lisa " e a outra de " muito rugosa ". Depreende-se, portanto, que uma é baseada na percep ção visual à distância de metros, a outra na percepção tãctil- / visual, e a última, à apreciação de perfis ampliados da microrugosidade.

Pretende-se, assim, identificar e enunciar o problema, de clinando-se de tentar apresentar aqui uma sugestão para adoção de critérios de rugosidade, pois acredita-se ser prematuro. o assunto constitui-se em interessante motivação para trabalhos posteriores, devendo ser complementado com a coleta de novos da dos, e estabelecer uma escala de rugosidades e outra de micro-rü gosidade.

Há, entretanto, alguns estudos recentes, destacando-se os de Coulson ( 1970 ) e de Barton ( 1971 ), em que a rugosidade é bem determinada; no primeiro caso, atravēs da média obtida de perfís de rugosidade e, no segundo, atravēs de fotogrametria,das superfícies ensaiadas. Deve-se mencionar que os critérios de rugosidade de ambos são arbitrários e sujetivos.

Coulson realizou uma grande série de ensaios em superfícies rochosas de vārias litologias e com diferentes rugosida des, produzidas por diferentes processos de preparação. Dos en saios, concluiu que os coeficientes iniciais de atrito aumentam com o aumento da rugosidade; que a presença de āgua pouco in flue no coeficiente de atrito de atrito das superfícies mais rugosas; e que o coeficiente de atrito residual também cresce com 
6.4

a rugosidade,para baixas tensões até $7 \mathrm{Kg} / \mathrm{cm}^{2}$, mas que para al tas tensões é uma função do tipo de destruição da superfície. No entanto, a influência da rugosidade' no atrito não ficou quanti tativamente estabelecida no trabalho de Coulson, razão pela qual procedeu-se tentativamente à correlação procurada, que foi possível graças a boa documentação fornecida no trabalho de Coulson. As Figuras 6.3, 6.4, e 6.5, apresentam os vārios coeficientes de atrito de superfícies de rocha sêcas e saturadas, em função da rugosidade média determinada por Coulson, e para duas diferentes tensões normais. Pode-se observar que para vārios dos gráficos há uma clara correlação entre o aumento do coeficiente de atrito com o aumento da rugosidade ( algumas paucas excessões podem ser atribuidas a um resultado diferente da rugosidade sob condições uniformes de preparação mecânica ) • De um modo geral, nota-se que os coeficientes de atrito iniciais sêco e saturado, crescem da ordem de 0,1 para cada 0,005 mm de aumento da rugosidade média ( com excessão da condição saturada sob $\sigma_{n}=30 \mathrm{Kg} / \mathrm{cm}^{2}$ ). Por sua vez, os coeficientes de atrito re sidual, sêco e saturado, não sofrem quase influência da rugosida de ( com excessão da condição sêca para $\sigma_{\mathrm{n}}=0$, que fornece grande dispersão) - Os coeficientes mínimos de atrito parạ o ca so sêco seguem a mesma tendência dos coeficientes iniciais sêços e os coeficientes mínimos saturados assemelham-se aos residuais saturados ( embora com valôres mais baixos). Esses incrementos observados, contudo, são válidos para rugosidades mesuráveis ape nas por instrumentos, e não se conhece como progridirão com o progressivo aumento da rugosidade ou micro-rugosidade, acreditan do-se que após um certo limite, ainda indeterminado, passem a ví gorar as relações deduzidas por Patton ( 1966a) e Barton (1971) para rugosidade de maior escala. As conclusões de Barton já fou ram apresentadas no ítem 2.4 acima.

São decorrentes de análise experimental de superfícies irregulares, produzidas por compressão diametral e, embora se possa definir uma rugosidade média, procede à correlação entre o ângulo das mesmas com a resistência, sem considerar a magnitu- 


\section{5}

de das irregularidades. Para que esta ültima possa teoricamente ser correlacionada à resistência ao cisalhamento, é necessário adotar uma geometria para as irregularidades. Lambe

Whitman ( 1969 ) fornecem grandes ampliações de irregularidades reais, indicando terem aproximadamente a forma de senōide. Admi tindo essa forma como verdadeira, e que as expressões de Barton são aplicáveis, procedeu-sea uma correlação teórica, tentativa e preliminar, entre a variação da resistência e a dimensão das ir regularidades, como ilustrado na Figura 6.6. Admitindo, tambēm, que as irregularidades têm um comprimento de onda e uma amplitude, e aplicando a expressão de Barton, chega-se a uma curva que relaciona a amplitude das irregularidades ao coeficinete de atri to. A forma da curva, aproximadamente paralela à que representa a expressão de Barton, indica que em linhas gerais a relação ē válida, o pequeno desvio com relação à curva de Barton deve ser reflexo da adoção da hipótese simplificadora de que a rugosi dade tem a forma ideal de uma senóide.

Dessa forma, em primeira aproximação, o estudo feito com base nos ensaios de Coulson pode fornecer os subsídios necessārios para a estimativa da influência da micro-rugosidade no coeficiente de atrito de superfícies lisas de rocha, e o estudo teó rico tentativo, aplicando a expressão de Barton fornece as idéias bāsicas de influência da rugosidade, expressa em dimensão, no coeficiente de atrito de superfícies de fratura.

6.3 - Influência da Espessura da Camada de Preenchimento $\underline{\text { na }}$ Resistência ao Cisalhamento de Fraturas.

A comparação dos valôres de resistência ao cisalhamento com variação da espessura do preenchimento não tem sido siste matica ou pelo menos com suficiente sistemática para alcan çar-se boa apreciação da sua influência. Sabe-se apenas, dos vá rios ensaios realizados, tanto em laboratório, quanto " in situ ", 
na sua maior parte em apenas duas espessuras diferentes de preenchimento, que a resistência é menor quanto maior essa espes sura.

Numa tentativa de estabelecer a proporção em que se dã essa diminuição de resistência, os poucos dados disponĩveis fo ram lançados no desenho da Figura 6.7. Levando em conta a diver sidade de tipos de ensaios e de materiais ensaiados, considerase muito boa e promissora a tendência revelada pelo desenho. Al guns dos dados, mais completos, parecem indicar que a relação tende a fornecer curvas assintóticas, para fornecer um valor constante de $\varnothing$ após atingido um certo valor de espessura de preenchimento, próprio para cada material. o aumento de $\varnothing$ com a diminuição da espessura poderia ser atribuido ao maior nümero de pontos de contacto das superfícies da rocha, entre si, anulando progressivamente, o efeito da presença do preenchimento, fenômeno similar ao descrito por Tulinov e Molokov ( 1971 ). Ês se valor limite, em que a resistência não é mais afetada, parece ser da ordem de 5 a $10 \mathrm{~cm}$ (embora sejam necessārios mais dados para sua confirmação ), espessura a partir da qual as irregularidades da superfície de rocha não mais interferem por não alcança rem usualmente tais dimensoẽs.

6.4 - Relação entre o Ângulo de Atrito dos Solos e seus Contac tos com Propriedades Indides dos Solos ( Limites de Atterberg ).

Vārios investigadores têm apresentado algumas correlações tentativas entre o ângulo de atrito e algumas propriedades indices do solo, sendo que a maior parte delas usam o indice de plas ticidade e, algumas poucas, o limite de liquidez. Considera-se que dessas correlações apenas os valôres correspondentes aos solos amolgados ou aos ângulos residuais são pertinentes a êste es tudo. 
Na Figura 6.8 os valôres encontrados nêste estudo e fornecidos na Tabela 5.1, são representados em relação aos índices de plasticidade respectivos dos solos, e na Figura 6.9, aos limi tes de liquidez respectivos. Apenas os solos ensaiados a vārias tensões normais foram considerados para essa relação.

Uma vez que os valôres dos ângulos de atrito apresentam variação com a tensão normal, foram representados nas Figuras 6.8 e 6.9 os ângulos de atrito correspondentes a baixas e altas tensões, fornecendo, respectivamente, os valôres mais altos e mais baixos de ângulo de atrito.

Conclui-se, pelo exame das figuras, que uma correlação entre $\varnothing$ e as propriedades indices dos solos parece evidente e, pela comparação das curvas que unem os pontos de ensaios de mesma categoria, constata-se que os ângulos de atrito corresponden tes ao contacto solo-rocha polida são inferiores aos do contacto solo-rocha serrada, que por sua vez são menores que os do solo. As mesmas relações foram encontradas usando o indice de plastici dade ou o limite de liquidez.

Para efeito de comparação, são tambēm apresentados nes sas figuras os dados colhidos da bibliografia, e relativos a solos amolgados. Em uma revisão, constatou-se que alguns autores fornecem valôres máximos, e outros os mínimos obtidos, où ain da ambos. Por isso, em cada uma das Figuras 6.8 e 6.9 os valô res de $\varnothing_{\max }$ e $\varnothing$ min obtido são lançadas separadamente.

Observa-se que os dados obtidos da bibliografia locali zam-se dentro da faixa definida pelas curvas solo a baixas ten sões e solo-rocha a altas tensões, e parecem confirmar a forma de faixa e das curvas que representam os resultados deste estudo Algumas poucas excessões, abaixo do limite inferior na Figura 6.9, correspondem a alguns folhelhos argilosos de comportamento reconhecidamente anormal ( como os da Formação Cucaracha, Panamā, e o "Pierre Shale ", E.E.U.U. ), bem como um valor excessivamen te alto ( solo de ottawa, Canadá); contudo, é ainda possível que as propriedades índices não tenham sido bem caracterizadas. Vale ainda frizar que a posição dos värios pontos numa mesma li 
6.8

nha vertical desses gráficos deve variar de conformidade com o nível de tensões aplicado, o que não foi levado em conta para a construção dos gräficos. Isso tambëm poderia ser uma causa para as excessões de valôres muito baixos.

Nessa comparação tambēm se pode notar que os valiôres de Ømin obtido correspondem aos valôres de Øres., principalmente em vista de coincidência com os resultados de Bishop et al (1971), com excessão do solo " Goose Lake Flour ".

As curvas resultantes da relação entre $\varnothing$ e o indice de plasticidade são reapresentadas na Figura 6.10a, a tîtulo de su mário. Na Figura $6.10 b$ as mesmas curvas são comparadas com ou tras curvas existentes e obtidas da bibliografia. Nota-se em am bas as figuras que a faixa hachuriada è delimitada pelas curvas que representam фmáx e ømin, tendo as duas aproximadamente a mesma forma. Resulta daí que a influência do nîvel de tensões ê - de deslocar verticalmente as curvas, sem afetar-lhes a forma. Isto é confirmado na comparação com outras curvas publicadas por Mitchell ( 1965 ), Brooker e Ireland ( 1965), e a curva de Skempton - Gibson - Bjerrum apresentada por Bjerrum e Simons ( 1960 ). A curva de Ømax ë praticamente coincidente com a de Brooker e Ireland, obtida para ensaios com tensões normais de 1 a $3 \mathrm{~kg} / \mathrm{cm}^{2}$, iguais aproximadamente ãs dêste estudo. Os ensaios de Mitchell foram feitos a $\sigma_{n}=1,2 \mathrm{Kg} / \mathrm{cm}^{2}$. As tensões normais da curva de Skempton - Gibson - Bjerrum não são conhecidas, mas suspeita-se que sejam bem mais elevadas que as acima.

Comparando a curva dos resultados mais baixas publicados, ou seja, a de Skempton - Gibson - Bjerrum (Figura 6.10a) e que é usualmente adotada para a estimativa de $\varnothing$ a partir das propriedades indices, com a curva Øres ou Ømin obtido dos contactos solo-rocha polida (Figura 6.10b), percebe-se que esta última ē de 60 a 9: mais baixa. A maior diferença corresponde aos solos de menor indices de plasticidade. Essa diferença pode ser de grande importância em problemas práticos que solicitam a resistência ao cisalhamento de solos ou contactos solo-rocha, e quando for necessārio estimar os parâmetros de resistência a - 
partir das propriedades indices, como em situações de estudos de viabilidade, anteprojeto, etc, e quando não se dispõe de tempo para a realização de ensaios.

\section{5 - Resistência ao Cisalhamento de Contactos de Solo com Ro- cha e outros Materiais de Construção}

A menor resistência de contacto solo-rocha, em compara ção com a do solo, é um fato que encontra paralelo com a de contactos de solo com concreto, ou outros materiais de construção, tais como, madeira e aço, conforme demonstrado nos trabalhos de Potyondy ( 1961 ) e de Chuang e Reese ( 1969 ). As pesquisas da resistência dos contactos solo-concreto, por exemplo, interessam aos casos correntes de fundações e obras de terra, em que ambos os materiais estão em contacto, e onde a resistência ao cisalha mento pode ser mobilizada. Conforme demonstrado tambēm por ês ses estudos de Potyondy e de Chuang e Reese, a resistência ao cisalhamento no contacto é menor que a do solo, e a redução de resistência, comparativamente à do solo pode ser expressa por um coeficiente de redução, $\alpha$, representando a relação entre a resistência do contacto e a do solo propriamente dito. Esse coe ficiente, ao mesmo tempo, é um coeficiente de correção, normal mente menor que 1 , pelo qual deve: ser multiplicada a resistên. cia do solo para obter a do contacto desejado.

Apresenta-se na Figura 6.11 os resultados obtidos neste estudo, conjuntamente com os de Potyondy, em têrmos de $\alpha$, mos trando as correlações que podem ser feitas para as várias condições de superfícies de rocha e de concreto, madeira, e aço. Para comparação entre os tipos de acabamento entre as superfícies dos vārios materiais utilizados, pode-se recorrer aos perfís de rugo sidade fornecidos nas Figuras 3.3 a 3.7 .

Em uma apreciação geral, nota-se que coeficientes da ordem de 0,4 podem facilmente ser alcançados, indicando que a 


$$
6.10
$$

adoção do ângulo de atrito do contacto solo-rocha ( em muros de arrimo ou para a resistência lateral de estacas ) , como sendo igual a $2 / 3$ de $\varnothing$ do solo, como é convencionalmente feito em Me cânica dos Solos, requer revisão pois em alguns casós estará con tra a segurança. 


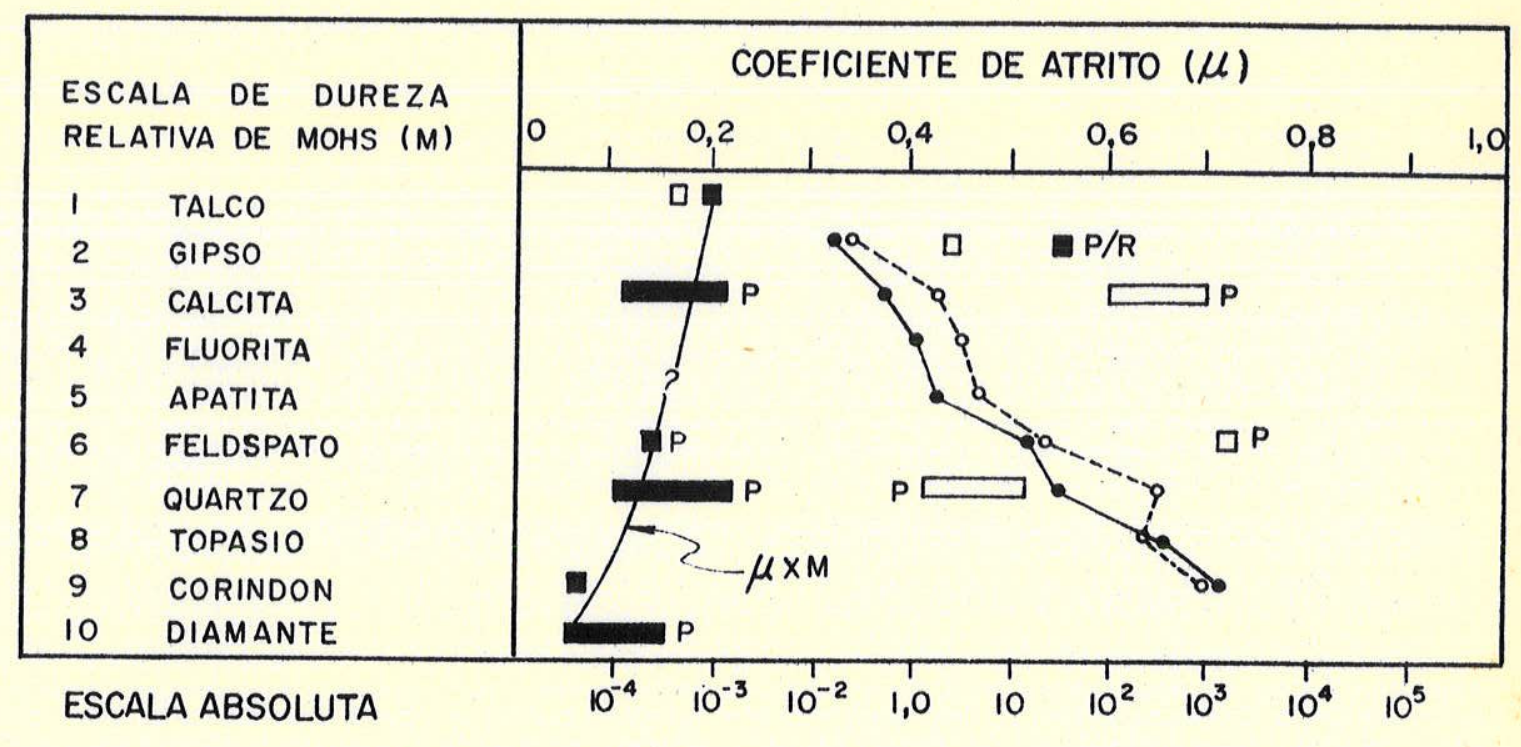

LEGENDA

ESCALAS DE DUREZA (FONTE:DUNCAN, 1969)

$\longrightarrow$ Jaggar (MICROESCLERÔMETRO)

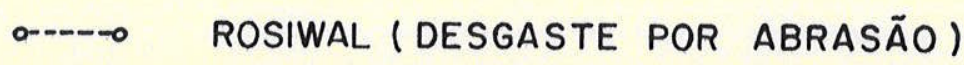

- SECO $\square$ SATURADO P-POLIDO R-RUGOSA

FIG. 6.1-RELAÇÃO ENTRE O COEFICIENTE DE ATRITO $(\mu)$ E A DUREZA DOS MINERAIS 


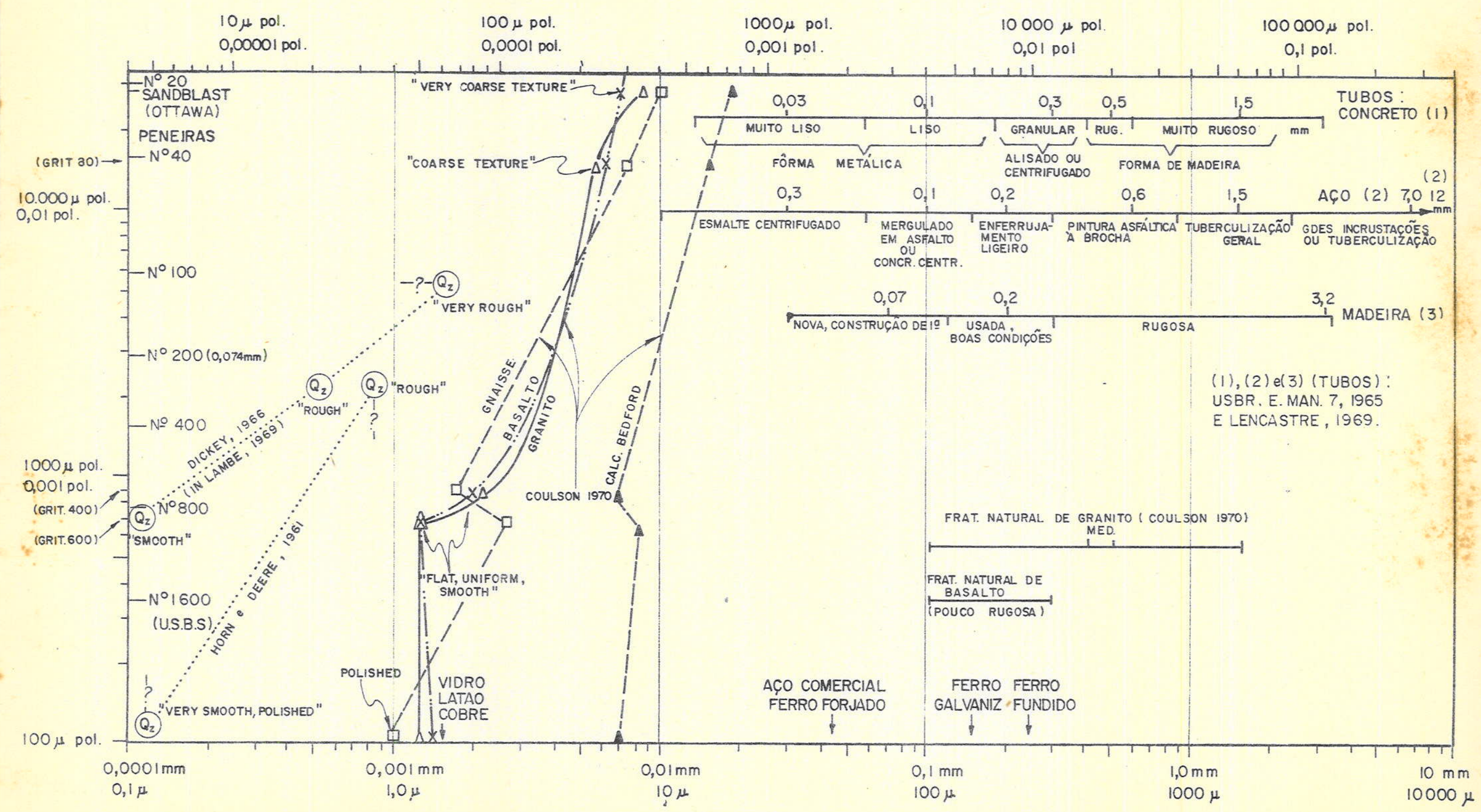

FIG. 6. 2-ILUSTRACÃO DE VÁRIOS CRITÉRIOS DE RUGOSIDADE COMUMENTE ADOTADOS 

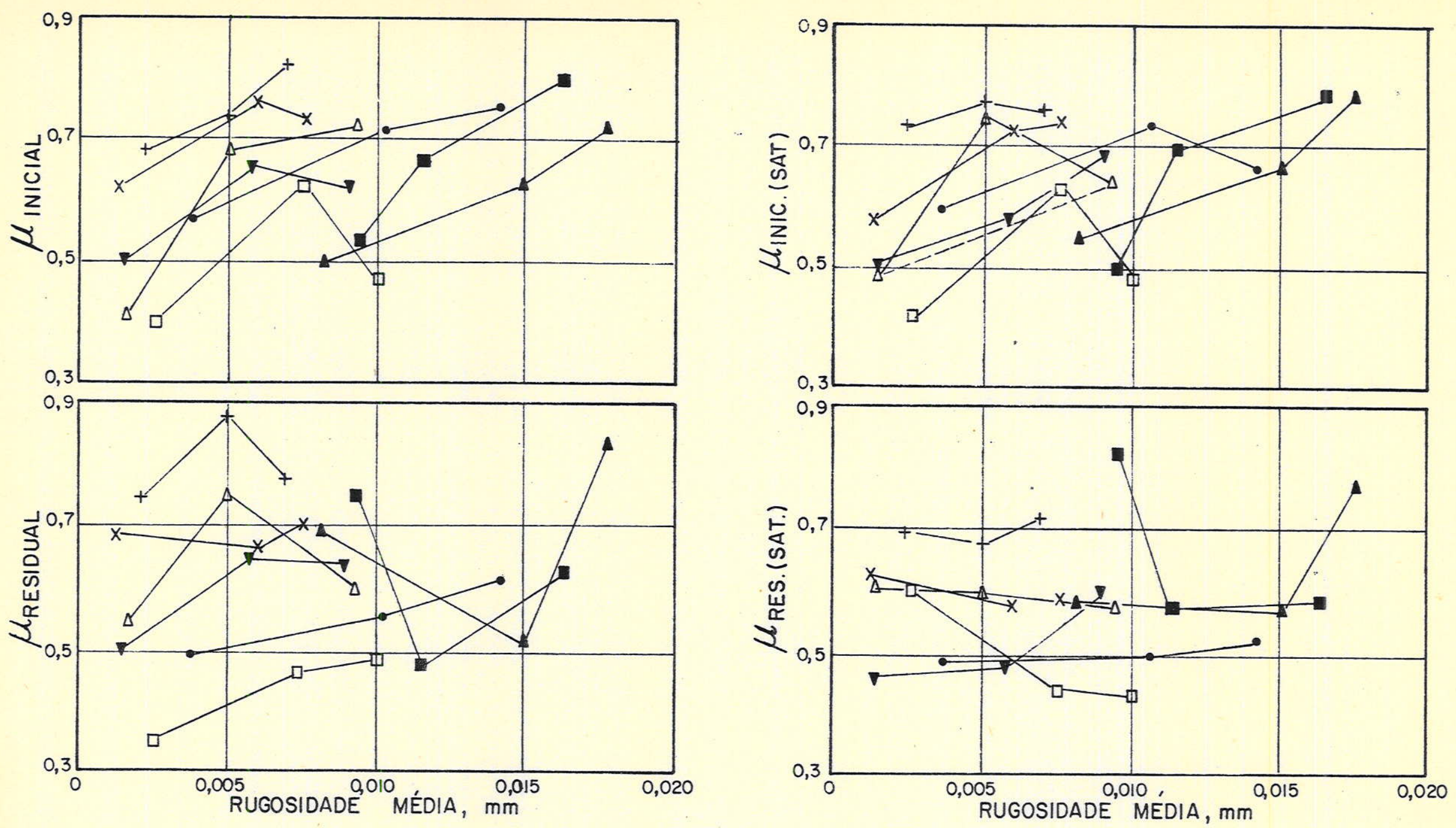

$X$ BASALTO "LOWER GRANITE" $\triangle$

- DOLOMito "ONEOTA"

GRANITO (BARRAGEM GRAND COULEE)

ARENITO "BERIA"

$\triangle$ CALCÁREO DE"BEDFORD"- $\square$ GNAISSE XISTOSO

+ CALCÁREO DE"SOLENHOFEN" $\nabla$ SILTITO "HACKENSACK"

FIG. 6.3 - GRÁFICOS DOS COEFICIENTES DE ATRITO (INICIAL E RESIDUAL) VS RUGOSIDADES MÉDIAS DE SUPERFICIES ROCHOSAS $(\sigma=0)$ COM BASE EM ENSÁIOS DE COULSON (1970) 

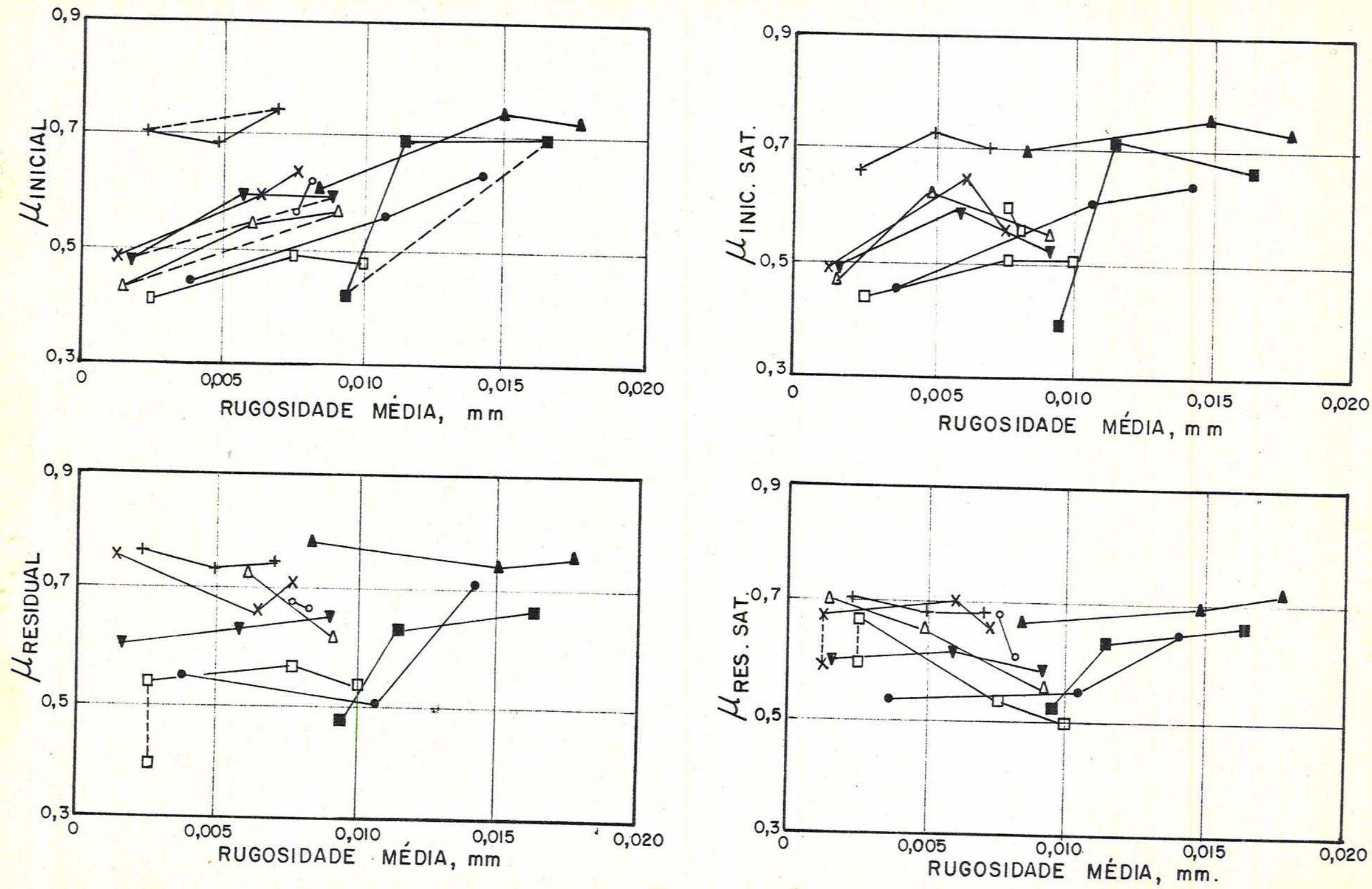
FIG. 6.4 - GRÁFICOS DOS COEFICIENTES DE ATRITO (INICIAL E RESIDUAL) VS. RUGGOSIDADES MÉDIAS
DE SUPERFICIES ROCHOSAS $\left(O_{n}=30 \mathrm{~kg} / \mathrm{cm}^{2}\right)$ COM BASE EM ENSAIOS DE COULSON (I970) 

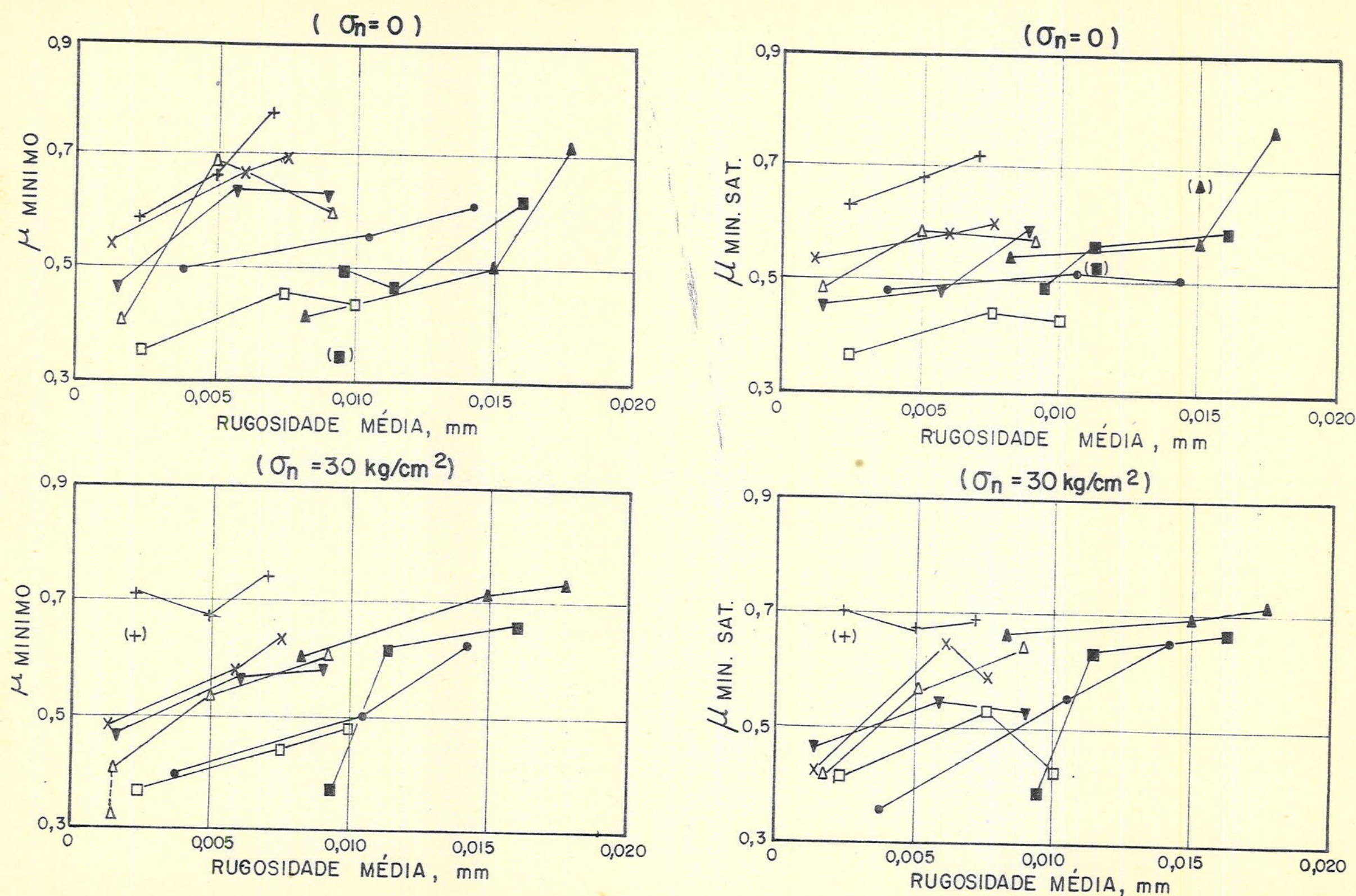
FIG. 6.5 - GRÁFICOS DOS COEFICIENTES DE ATRITO (MINIMOS) VS. RUGOSIDADES MÉDIAS DE SUPERFICIES
ROCHOSASI On $=0$ e $30 \mathrm{~kg} / \mathrm{cm}^{2}$ ICOM BASE EM ENSAIOS DE COULSON (I970) 


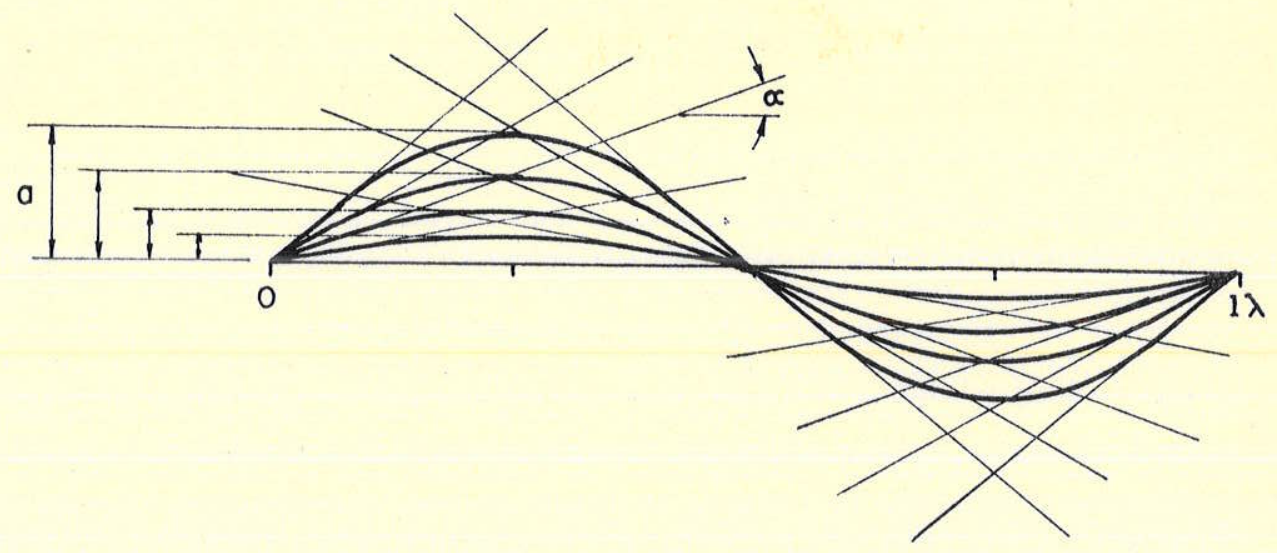

\begin{tabular}{|c|c|c|}
\hline$\alpha=d_{n}$ & $\begin{array}{c}2 a \cdot \lambda \\
(\lambda=20)\end{array}$ & $\begin{array}{c}2 a \\
\text { rugosidade } \mathrm{mm}\end{array}$ \\
\hline $10^{\circ}$ & 160 & 0,8 \\
\hline $20^{\circ}$ & 360 & 1,8 \\
\hline $30^{\circ}$ & 680 & 3,4 \\
\hline $40^{\circ}$ & 1080 & 5,4 \\
\hline
\end{tabular}

$$
\mu=\tau / \sigma=\tan \left[2 d_{n}+30\right]
$$

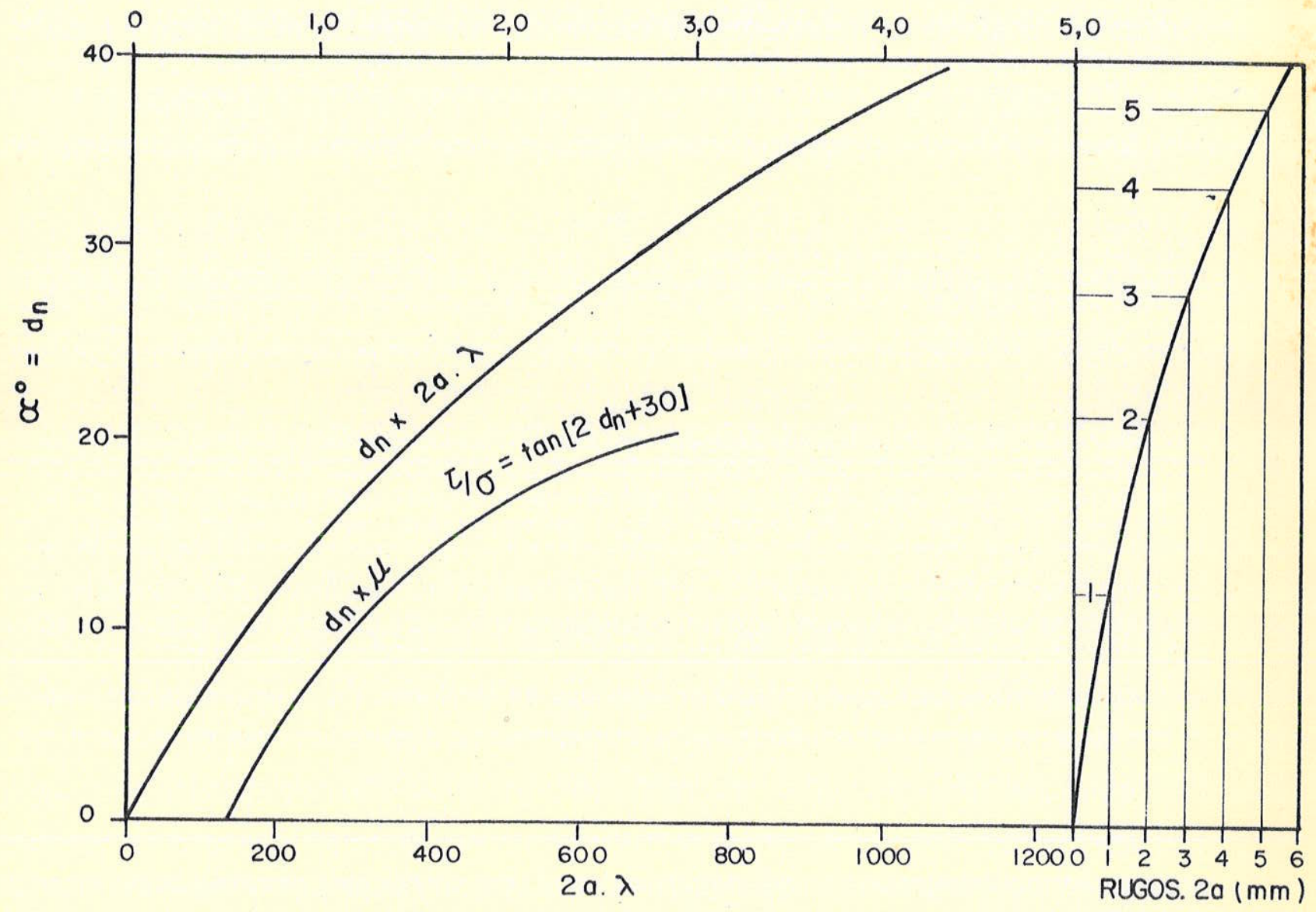

FIG. 6.6 - CORRELACÃO TEÓRICA TENTATIVA ENTRE A RUGOSIDADE E O COEFICIENTE DE ATRITO 


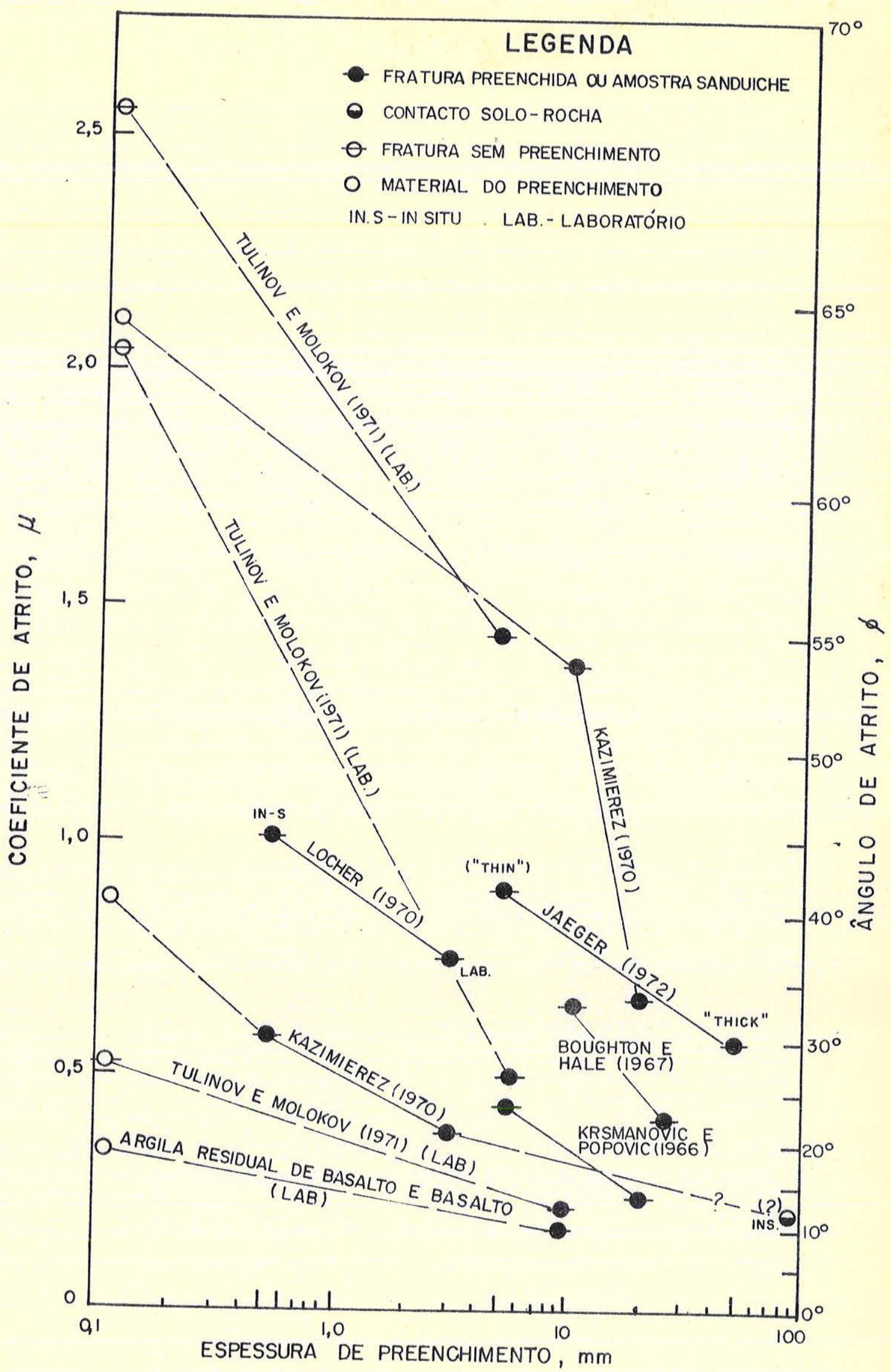

FIG. 6.7- EFEITO DA ESPESSURA DO PREENCHIMENTO DE DESCONTINUIDADES NO ANGULO DE ATRITO. 

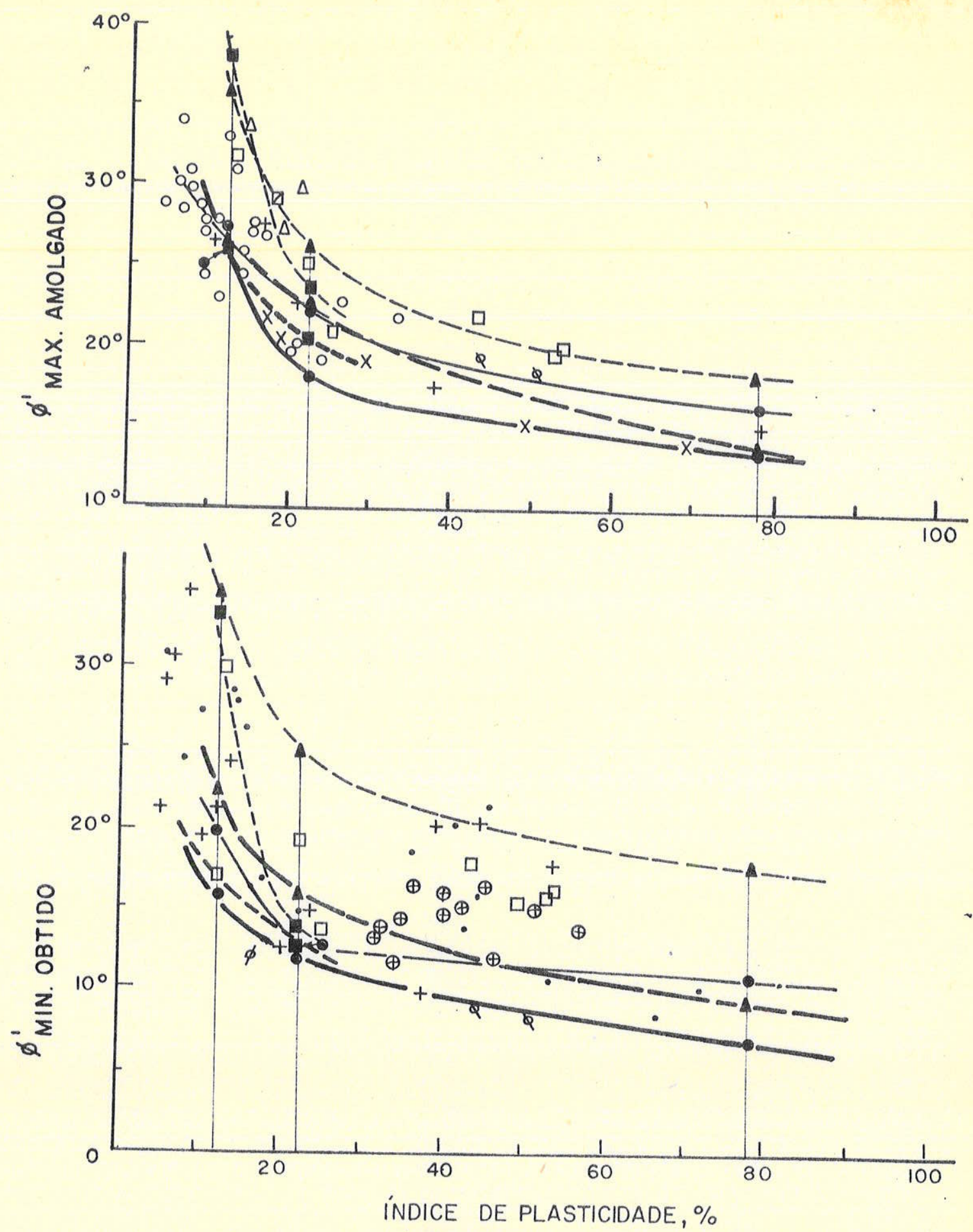

LEGENDA

ESTE ESTUDO

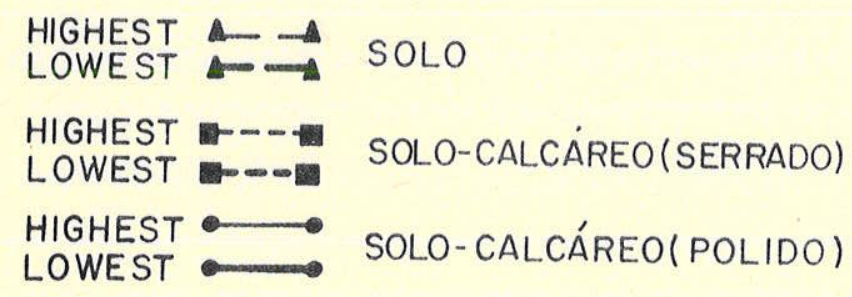

DADOS DA BIBLIOGRAFIA

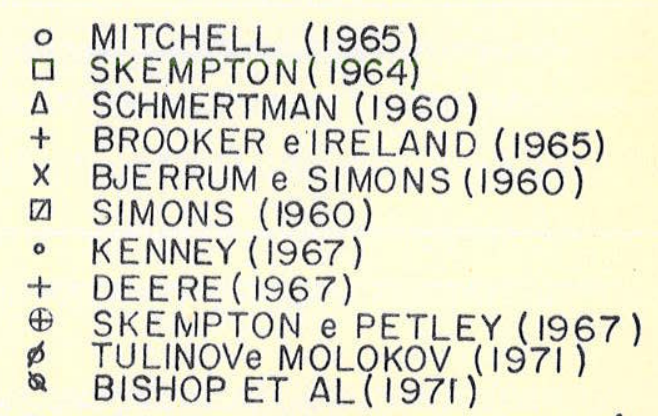

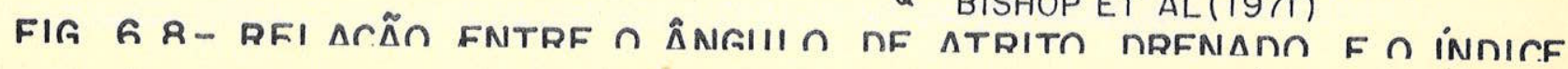



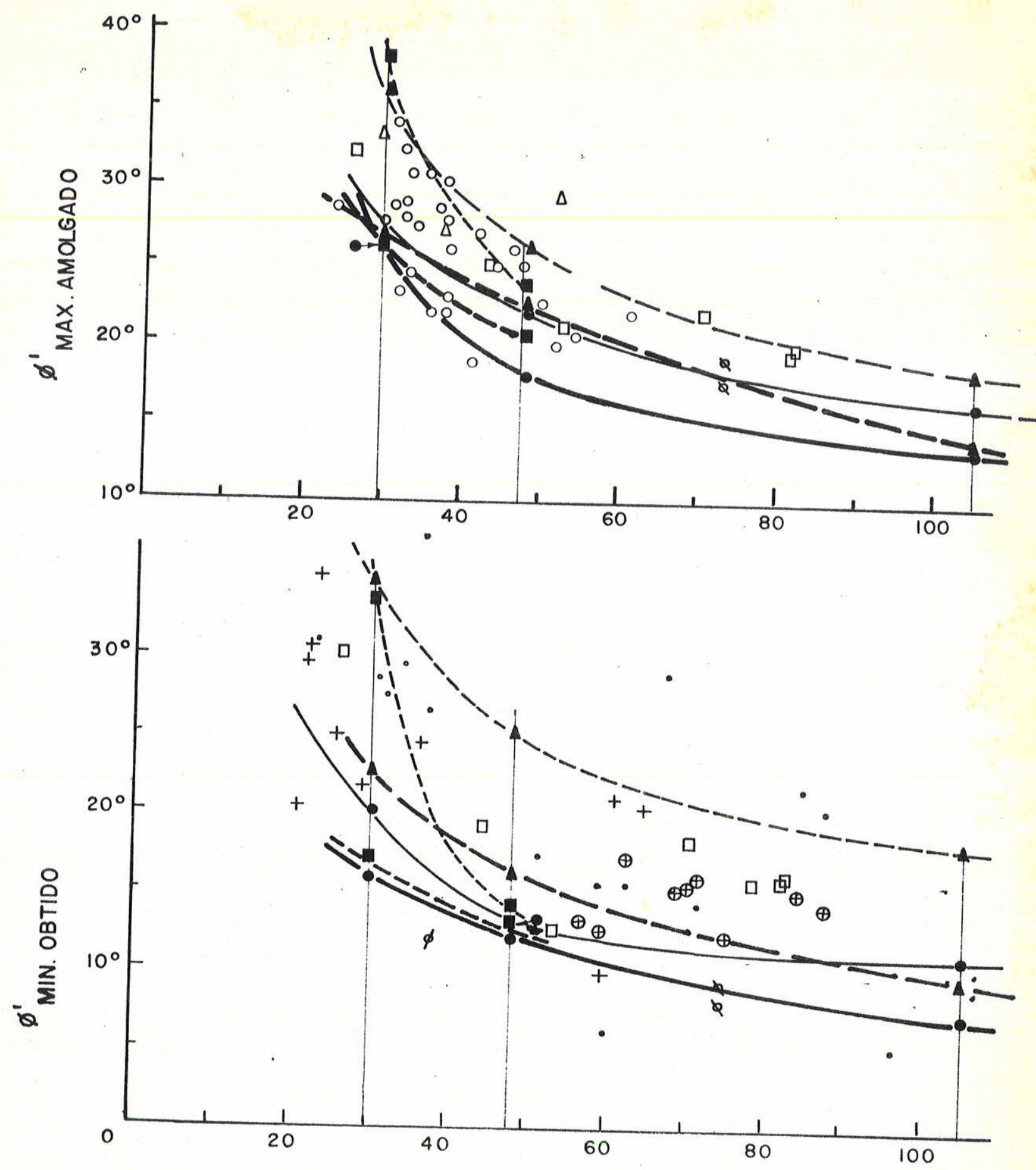

LIMITE DE LIQUIDEZ, \%

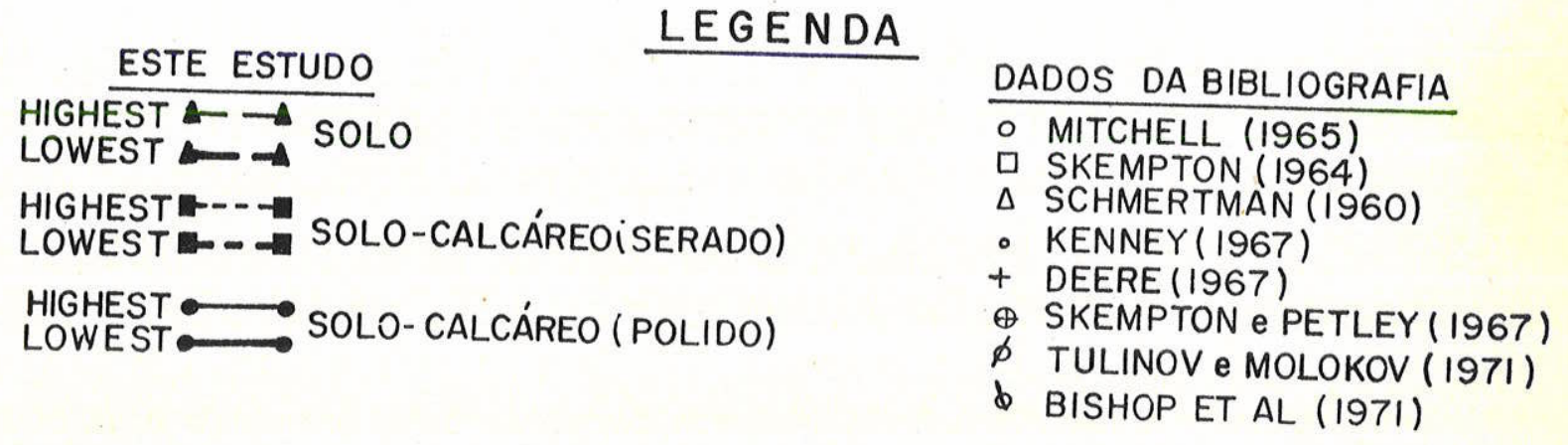

FIG.- 6.9 - RELAÇÃO ENTRE O ÂNGULO DE ATRITO (DRENADO) E O LIMITE 

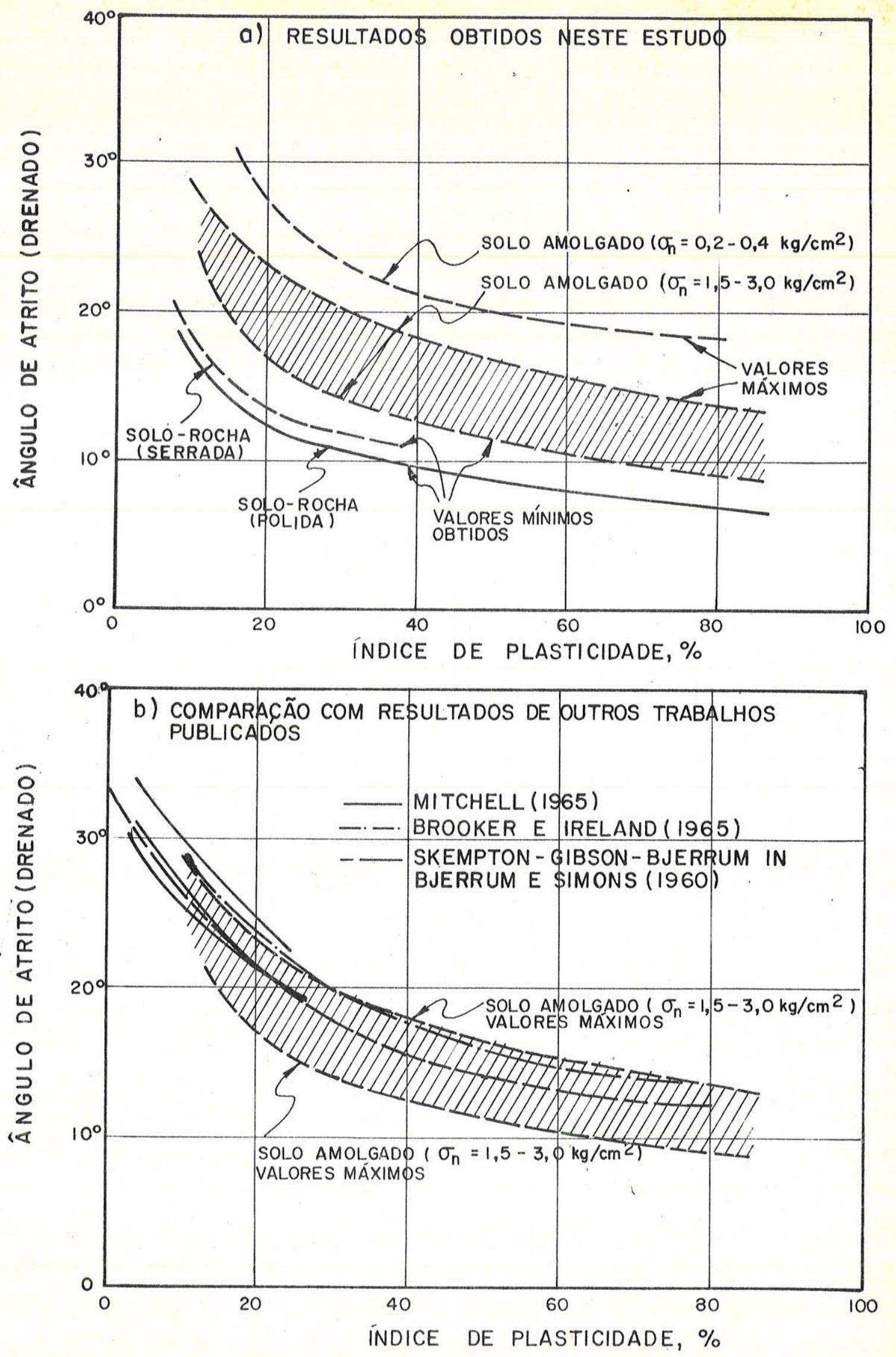

FIG. 6. IO- COMPARACÃO DAS CURVAS RELACIONANDO ÂNGULO DE ATRITO (DRENADO) COM O INDICE DE PLASTICIDADE OBTIDOS NESTE ESTUDO COM RESULTADOS DE OUTROS TRABALHOS PUBLICADOS 


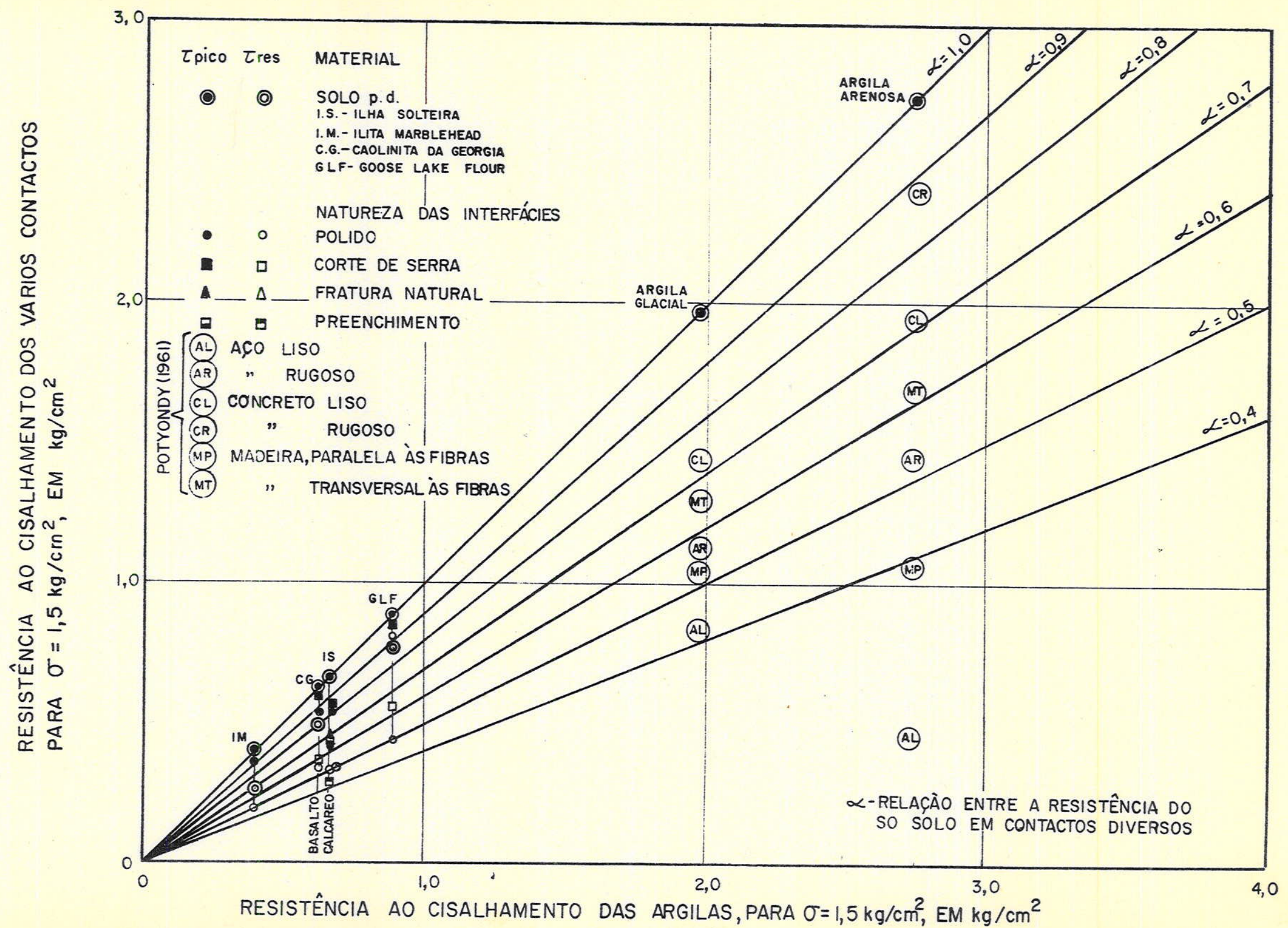

FIG. 6.II-COMPARAÇÃO DOS COEFICIENTES DE REDUÇÃO DOS CONTACTOS ENTRE SOLO, ROCHA E OUTROS MATERIAIS DE CONSTRUÇÃO 


\section{CONCLUSÕES}

Dos resultados dos ensaios laboratoriais realizados em vários solos amolgados, com propriedades indices distintas, em combinação com dois tipos de rocha diferentes, e à luz da revisão feita da literatura correlata, pode-se chegar às conclusões a se guir apresentadas.

1 ) - Para os deslocamentos máximos permitidos pelo equipamento a resistência ao cisalhamento dos contactos solo-rocha mostrouse inferior à do solo, sendo tanto menor quanto mais regular e lisa for a superfície rochosa do contacto. A redução do ângulo de atrito variou de 10 a 14,5 : para baixas tensões normais (até aproximadamente $1,5 \mathrm{Kg} / \mathrm{cm}^{2}$ ), até $2,5 \circ$ a 6,50 a maiores tensões normais ( até aproximadamente $3 \mathrm{Kg} / \mathrm{cm}^{2}$ ).

2 ) - Tendo ocorrido maior redução para as superfícies lisas que para as serradas, os resultados são mais significativos a sí tuações geolōgicas onde o solo estiver em contacto com superfi cies polidas, ou com estrias de atrito ( "SLIKENSIDES " ), acama mentos regulares, ou outros tipos de superfỉcies lisas em contaç to com solo como,por exemplo, as paredes de uma falha em contac to com milonito alterado.

3 ) - Alcança-se os valôres de $\tau$ min. obtido a muito menores deslocamentos no caso dos contactos do que no de solo apenas. Em particular, as resistências máximas ( picos ) foram obtidas a dí ferentes magnitudes do deslocamento. Essas condições podem favô recer o desenvolvimento do mecanismo de rutura progressiva, pois, enquanto umas partes da superfície de rutura não mobilizam ainda 


\section{2}

a resistência māxima, outras partes, sob mesma condição de solicitação, jã teråosua resistência máxima ultrapassada.

4 ) - A curva correlacionando valôres de Ø̆min obtido com o indice de plasticidade para contactos solo-rocha polida é de $6 \%$ a 98 abaixo da curva mais baixa publicada indicando a relação en tre $\varnothing$ e indice de plasticidade. Essa redução pode ser bastante significativa em projeto ou análise de estabilidade no caso de ocorrerem as situações geológicas aplicáveis.

5 ) - A correção devida à redução da ārea do corpo de prova com o deslocamento deveria ser feita quando se realizam ensaios de cisalhamento direto, e os respectivos gráficos deveriam conter as " trajetōrias de tensão " relativas. Sugere-se que as " trajetōrias de tensão " sejam empregadas como elemento de julgamento do andamento do ensaio, e como um critērio para determinar se a resistência residual jã foi alcançada.

6 ) - Conclui-se, tambēm, que um ensaio de cisalhamento direto de espécimes compostos de solo e rocha polida, constitui-se num processo alternativo para desenvolver a resistência residuăl de um solo, aproveitando dos equipamentos comerciais e comuns aos laboratórios de Mecânica dos Solos, em ensaios simples, rápidos e econômicos. Os ensaios sofisticados por meio de aparelhos de cisalhamento por torsão, contudo, podem se constituir em elemen to de aferição de amostras representativas ou casos especiais. Fornece-se a explicação tentativa de que a resistência residual em amostras de contactos se produz a relativamente pequenos des locamentos pela facilidade de orientação das partículas lamelares de argila junto à superfície de rocha. o tipo litolōgico da rocha tem importância secundāria com relação à geometria da sua superficie. Este fato é comprovado pela semelhanda dos coeficientes de redução da resistência dos solos quando em contactos com materiais diversos ( rocha, concreto, madeira, aço, ).

7 ) - Perante as variações de velocidade de deslocamento ou 


\section{3}

de deformação, os solos mostraram-se praticamente insensíveis, indicando apenas ligeiro aumento da resistência ao cisalhamento com o aumento da velocidade, dentro dos limites de variação. Nos contactos, constatou-se que a queda de resistência, apōs o pico de resistência mâxima, é tanto mais rápida quanto mais lento o deslocamento.

81 - Ressente-se do fato de que grande número de dados publicados não possam ser aproveitados devido à insuficiente caracte rização do espécimen ou das condições do ensaio.

No caso dos dados de Coulson, bem documentados, foi possível elaborar correlação entre o atrito e a rugosidade a fornecida. No entanto, a falta de caracterização quantitativa de Potyondy impediu essa mesma correlação para contactos de solo com vārios materiais de construção. Dessa forma, sugere-se que os resultados de ensaios sejam apresentados com a caracterização necessária, levando em conta os fatôres reconhecidos nêste estudo.

9 ) - Com relação alguns dos fatôres tratados no item 6, chega se a resultados que parecem indicar os seguintes pontos: que os coeficientes de atrito são maiores com a menor dureza dos mine rais; que a resistência ao escorregamento de superfícies rocho- sas aumenta em certas proporções com o aumento da sua rugosidade dependendo da ordem de grandeza da rugosidade, da magnitude dos deslocamentos, e da condição sêca ou saturada; que a espessura da camada de preenchimento influi na resistência ao cisalhamento, sendo esta menor, com o aumento da espessura. No entanto, deve ser ressaltado que tais conclusões são apenas parciais, requeren do estudos posteriores. 


\section{SUGESTÕES PARA INVESTIGAÇÕES POSTERIORES}

Em primeiro lugar, alguns dos estudos posteriores, principalmente se forem usados solos de granulometria mista, deveriam ser feitos com ensaios a maiores deslocamentos, da ordem de 1,5 a 2 vezes maiores do que os alcançados neste estudo, o que requeria a introdução de modificações em equipamentos co muns de cisalhamento direto. Ademais, a caixa superior deveria ser mais equilibrada e permitir a manutenção do espaçamento de sejado.

Para auxiliar nos estudos posteriores para a determina ção do estado de tensões em amostras no ensaio de cisalhamento direto seria de interêsse a construção de caixas especiais para acomodar a amostra, e providas de células medidoras das tensões, de modo similar ao realizado por Roscoe et al ( 1967 ) para en saios de cisalhamento simples.

$O$ estudo de alguns outros solos, com diferentes indi ces de plasticidade ( IP ) seria conveniente, para fornecer me thor definição às curvas de $\varnothing$ vs. IP as quais, visto terem sido traçadas com base em apenas três pontos cada, estão apenas ini cialmente delineadas. Sugere-se, tambēm, realizar os ensaios em equipamento de maior capacidade, para alcançar maiores tensões normais. Particularmente, ê de interêsse completar-se a sẻrie de ensaios com o uso de outros solos monominerálicos :especialmente da montmorilonita, da qual não se dipös para o presente es tudo.

Com relação à influência da rugosidade da superfície da rocha na resistência do contacto, não se pôde definir exata mente qual a maior dimensão da rugosidade passará a fornecer resultados idênticos aos do solo, pois é extremamente difícil pro- 


\section{2}

duzir superfícies rochosas com as variações desejadas na rugosi dade, principalmente com o aumento da sua escala. Sugere-se dessa forma, a realização de uma série de ensaios em contactos subs tituindo-se a rocha por outro material que permita a determina ção de rugosidades regulares, e da forma e dimensões desejadas,o que se poderia obter, por exemplo, por moldagem ou por vărios dos processos usados em Mecânica. Tais superfícies devem ser tambëm representadas por registros de perfiloógrafos.

Foi sugerido nêste texto que a mais rápida redução da resistência após o pico era devida à orientação das partículas de argila adjacentemente ao contacto com a rocha. Para comprovar esta idéia poderiam ser feitos estudos com o uso de técnicas es peciais de impregnação e exame microscópico, como mencionado por Morgenstern e Tchalenko ( 1967 ).

Notou-se em alguns dos ensaios, aos maiores niveis de tensão empregados, que alguns contactos exibem um comportamento que sugere a ocorrência de um modo composto de rutura; recomenda-se a investigação de tal tópico, principalmente mediante ensaios a tensões normais mais elevadas que as empregadas.

Tendo em vista que a resistência de fraturas preenchidas mostra-se variável com a resistência, seria de grande interês se proceder-se a ensaios variando a espessura do preenchimento e, separadamente, o tipo do mesmo.

Do ponto de vista do atrito entre superficies rochosas, é de se ressáltar a sugestão para a investigação visando a compa ração entre o atrito de superfícies de rocha, com os atritos individuais dos seus minerais constituintes, ponderadamente, de acôrdo com suas respectivas porcentagens de ocorrência. 


\section{B. I}

\section{REFERÊNCIAIS BIBLIOGRÅFICAS}

Barton, N.R• (1971) - " A relationship between Joint Roughness and Joint Shear Strength", Int. Symp. Rock Mechanics, Rock Fracture, Nancy, $20 \mathrm{pp}$.

Bishop, A. $I_{\bullet}, G_{\bullet}$. Green, V.K. Garga, A. Andresen e J.D. Brown (1971) " A New Ring Shear Apparatus and its Application to the Measure ment of Residual Strength ", Geotechnique, Vol. 2l, n\& 4, p.273 328.

Bjerrum, L. (1967) - " Progressive Faiture of Slopes on Overconsolida ted Plastic Clay and Clay-Shales ", The Third Terzaghi Lecture, Jour. Am. Soc. Civ. Ing., Vol. 93, SM 5, Part. 1.

Bjerrum, L., e N.E. Simons ( 1960) - " Comparison of shear strength characteristics of normally consolidated clays ", Amer. Soc. Civ. Engrs., p. 711-726.

Boughton, N.O. e G.E.A. Hale ( 1967)- "Foundation Studies for Cethana Arch Dam ", 90 Int. Conf. Large Dams, Istambul, Q.32, R.10, p.143-163.

Brooker, E. W., (1964) - " The influence of stress history on certain propertiss of remolded cohesive soils ", Ph.D. Thesis, Univ. of Illinois, $216 \mathrm{pp}$.

Brooker, E. W., e H. O. Ireland (1965) - " Earth pressures at rest related to stress history ", Canadian Geotech. Jour., Vol. 2, No. $1, p \cdot 1-15$.

Brown, T. E. (1968) - "The influence of planar discontinuities on the shear strength of a rock-like material ", Ph. D. Thesis, Univ. 
of Queensland, Australia, $287 \mathrm{pp}$.

Brown, E.T. e D.H. Trollope ( 1970 ) - " Strength of a Model of Jointed Rock ", Jour.Am. Soc.Civ.Eng•, Vol. 96, SM 2, p.685-704

Casagrande, A., e S.D. Wilson (1953) - "Pretress induced in consolidated quick triaxial tests ", Harvard Soil Mech. Ser. No. 42, reim pressão Proc. 3rd Int.Conf.on Soil Mech. and Foundation Engr., Switzerland, Vol. I, p. 106-110

Casagrande, A., e R.C. Hirschfeld (1960) - "Stress deformation and strength characteristics of a clay compacted to a constant dry unit weight "., Soils, Univ, of Colorado, p. 359-417.

Chuang, J.W. e L.C. Reese (1969) - " Studies of Shearing Resistance between Cement Mortar and Soil ", Center for High. Res., Univ• of Texas, Austin, Res. Rep. 89-3, 74 pp.

Corso, J.M. (1955) - "Notes on direct shear tests of remolded clays." Relatório não publicado, Harvard University, Cambridge.

Coulson, J. H. (1970) - " The effects of Surface Roughness on the Shear Strength of Joints in Rock ", (Ph.D. Thesis) Corps of Eng., Tech. Rep. No. MRD-2-70, $282 \mathrm{pp}$.

De Sitter, L.U. (1956) - "Structural Geology ", Mc Graw Hill Book Co., New York, 552 pp.

Deere, D. U. (1967) - " Shale Mylonites - Their origin and Inginee ring Properties ", Assoc. Engr. Geologists, Nat.Meeting Dallas, Texas.

Deere, D. U. e F.D. Patton (1971) - " Slope Stability in Residual Soils ", Rel. Estado da Axte, $4^{\text {th }}$ Pan-Am. Cof. on Soil Hech. and Found. Enis, Porto Rico, Vol.I, p. 87 - 190. 


\section{B. 3}

Department of the Army, Corps of Engineers ( 1965) - " Laboratory Soils Testing ", Engr. Manual, EM 1110-2-1910, EEUU, 7 pp., com 13 apendices.

Donath, F. A. (1961) - "Experimental study of shear failure in anisotropic rocks ", Geol. Soc. Amer. Bull., Vol. 72, p. 985-990.

Duncan, N. (1969) - "Engineering Geology and Rock Mechanics", 2 vol. Leonard Hill, Londres.

Gaudette, H. E., J.L. Eades, e R.E. Grim ( 1965) - "the nature of Illite ", reimpressão de Clays and Clay Minerals, Proc. $13^{\text {th }}$ Nat Conf., Madison, Pergamon Press, New York, p. 33-48.

Gibson, R॰E., e Henkel, D. J. (1954) - " Influence of duration of tests at constant rate of strain on measured drained strength", Geotechnique, Vol. 4, p. 6-15.

Giuseppe, B. (1970) - "The Shear Strength of Some Rocks by Laboratory Tests ", $2^{\text {nd }}$ Int. Conf. Rock Mechanics, Belgrado, Vol. 2, No.3 $-24,8 \mathrm{pp}$.

Goldstein, M. B. Goosev, N. Pyrogovsky, R. Tulinov e A. Turovskaya (1966) - "Investigation of mechanical properties of craked rock"

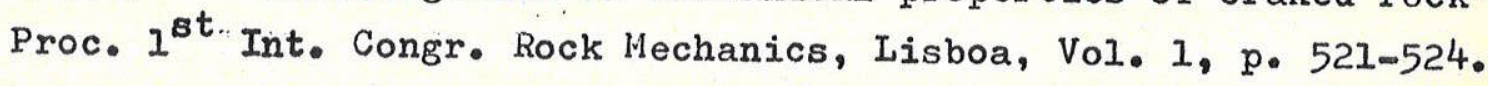

Grishin, M. M., e P. D. Evdokimov (1961) - "Shear strength of structures built on rock ", proc. 5th Int. Conf. Soil Mech. and Foundation ingr., Paris, Vol. 1, p. 646-654.

Horn, H. M., and D. U. Deere ( 1962). " Frictional characteristics of minerals ", Geotecnique, Vol. 12, p. 319-335.

Hvorslev, M. J. (1936) - " Conditions of failure for remolded cohesive soils ", Proc. 1st Int. Conf. Soil Mechanics and Foundation - 


\section{B. 4}

Engr., Cambridge, Vol. 3, p. 51-53.

Hvorslev, M. J. (1960) - " Physical components of the shear strength of saturated clays ", Amer. Soc. Civil Engrs., Research Conf. on Shear Strength of Cohesive Soils, Univ. of Colorado, p. 169-273.

Jaeger, J.C. (1959) - " The frictional properties of joints in rock" Geofis. Pura e Appl.', Vol. 43, p. 148-158.

Jaeger (1972 ) - " Rock Mechanics and Engineering ", Cambridge University Press.

Kanji, M.A. (1969) - "Resistência ao Cisalhamento ao longo de Interfácies Solo - Rocha ", Anais la Sem. Paul. Geol. Apl., APGA, Vol. 3, No.2, $12 \mathrm{pp}$.

Kanji, M.A. (1970) - " Shear Strength Along Soil - Rock Interfaces", M. S. Thesis, Univ. of Illinois, $69 \mathrm{pp}$.

Kanji, M. A. e S.N.A de Brito (1971) - "Condicionamentos Geológicos da Barragem de Jaguara ", Anais do $70 \mathrm{Sem}$. Bras. Grandes Barr., Rio de Janeiro, $16 \mathrm{pp}$.

Kazimierez, T. (1970) - " Étude de la Résistance au Cisaillement d'un Massif Calcaire Stratifié et Fracturé ", 2 nd Int. Conf. Rock Mechanics, Belgrado, Vol. 2, p. 3-27.

Kenney, T. C. (1959) - Discussão , Proc. Am. Soc. Civ. Eng•, Vol.85, SM 3, p. $67-79$.

Kenney, T.C. (1967) - "The influence of mineral composition on the residual strength of natural soils ", Proc. Geotech. Conf. on Shear Strength Properties of Natural Soils and Rock, Oslo, Vol. I, p. $123-129$. 
Krsmanović, D. (1967) - "Initial and residual shear strength of hard rocks ", Geotecnique, Vol. 17, p. $145-160$.

Krsmanovic, D. e Z. Langof ( 1964 ) - " Large scale laboratory tests of the shear strength of rocky material ", Rock Mechanics and Engr. Geol. ( Felsmechanik ), Suppliment I, p. 20-30

Krsmanovic, D., e M. Popovic (1966) - "Large scale field tests of the shear strength of Limestone ", Proc. Ist Int. Congr. Rock Mechanics, Lisboa, Vol. I, p. 773-779.

Krsmanović, D., M. Tufo e Z. Langof (1965) - "Some aspects of the rupture of a rock mass ", Rock Mechanics and Engr. Geol., Suppliment 2, p. 143-155.

Krsmanovic; D., M Tufo e Langof (1966)- " Shear strength of rock masses and possibilities of its reproduction on models ", Proc.

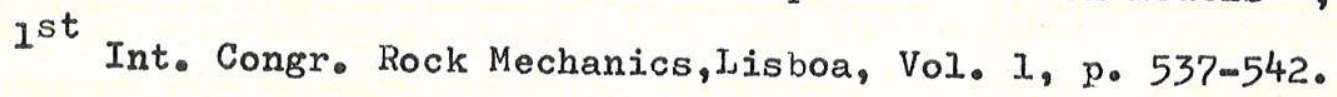

Kutter, H. K. e A. Figueiroa (1971) - " Investigation of a Simple Index Value for the Residual Shear Strength of Discontinuities in Rock " (Alem•), 20 Coll. Geomechanics, Salzburg ( in Rock" Mechanics Abs., Vol 3, No. 1, p. 53 ).

Kutter, H. K. (1971) - " Stress Distribution in Direct Shear Test Samples ", Int. Symp. Rock Hiechanics, Rock Fracture, Nancy, Vol. 2, $12 \mathrm{pp}$

Lajtai, E. Z. (1969) - "Mechanics of Second Order Faults and Tension Gashes ", Bol. Geol. Soc. Am., Vol. 80, p. 2253-2279.

Lambe, T. W. e R. V. Whitman (1969) - "Soil Mechanics ", John Wiley .\& Sons, New York, 553 pp.

Lane, K. S., e W. J. Heck (1964) - " Triaxial testing for strength of 


\section{B. 6}

rock joints ", Proc. 6th Symp. on Rock Mechanics, Univ. of Missouri, Rolla, p. 98-108.

Leussink, H•, e H. Müller-Kirchenbauer (1967) - "Determination of the shear strength behavior of sliding planes caused by geological features ", Proc. Geotech. Conf. on Shear Strength Properties of Natural Soils and Rock, Oslo, Vol. I, p. 131-137.

Locher, H. G. e Rieder, U. (1970) - " Shear Tets on Layered Jurassig Limestone ", $2^{\text {nd }}$ Int. Conf. Rock Mechanics, Belgrado, Vol.2, No. $3=1,5 \mathrm{pp}$.

Locher, H. G. (1968) - "Some results of direct shear tests on rock discontinuities", Int. Symp. on Rock Mechanics, Madx, p. 171-173.

Lombardi, G. e E. Dal Vesco (1966) - "Experimental Investigation on the Coeficients of Friction for the Rock abutments of the Arch Dam of Contra (Verzdsca)", $1^{\text {st }}$ Congr. Rock Mechanics, Lisboa, Vol. 1, p. 571-576.

Lorente de Nó, C. (1968) - "Elasto - Plastic Stress - Strain Ristribution During "In Situ "Shear Pests", Int. Symp. Rock Mechanics Madri,p. $183-187$.

Marsland, A., e M. E. Butler (1967) - "Strength measurements on stiff, fissured Boston Clay from Fawley, Hampshire ", Proc. Geotech. Conf. on Shear Strength Properties of Natural Soils e Rock, Oslo, Vol. I, p. 139-145.

Maurer, W. C. ( 1966 ) - "Shear Failure of Roch Under Axial e

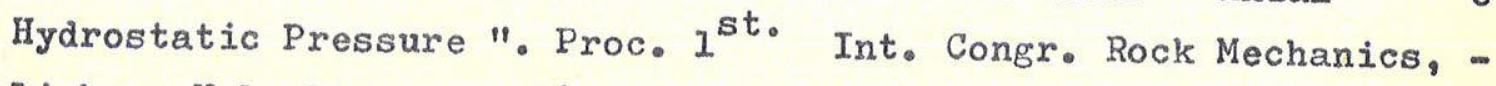
Lisboa, Vol. I, -p. 337-341.

Mello, V.F.B. e A.H. Teixeira ( 1960 ) - " Mecânica dos Solos, Fundaçōes e Obras de Terra ", Esc. Enge. S. Carlos, 2 Vols. 
Mello, V.F.B. ( 1966 ) - "Quod Memorandum est " com respeito aos ensaios de cisalhamento " in situ " em emprêgo na mecância das ro chas, Anais do III Cong, Bras, de Mec, dos Solos, B. Horizonte, Vol. 1, Tema VIII, p. 23-4I

Mitchell, N. W. R. ( 1965 ) - " Direct shear tests on thin samples of remolded shales form the Bighorn Mountains, Wyoming, "M.S. Thesis, Univ. of Illinois, $49 \mathrm{pp}$.

Morgenstern, N.R. e J.S. Tchalenko ( 1967 ) - "Microscopic Structures in Kaolin Subjected to Direct Shear ", Geotechnique, vol 17, p. $3090-328$.

Nieble, C.M. O.G. Guidicini ( 1972 ) - " 20 Anos de Ensaios de Mecânica das Rochas Aplicada Fundaçőes de Barragens ", O Empreiteiro No. 56, Setembro, p. 42-51.

Niederhoff, A.E. ( 1939 ) - "Field tests of a shale foundation "Proc. Amer. Soc, Civil Engrs, Vol 65, No. 2, p. 1239-1254.

Patton, F. D. ( 1966a ) - "Multiple modes of shear failure in rock e related materials, " $\mathrm{Ph}$. D. Thesis, Univ, of Illinois, Urbana, $282 \mathrm{p}$ :

Patton F. D. ( 1966b ) - "Multiple modes of shear failure in rock ", Proc. Ist Int. Congr. Rock Mechanics, Lisboa, Vol. I, p. 509-513.

Patton, F. D. ( 1968 ) - " The Netermination of Shear Strength of Rock Masses ", trabalho apresentado ao curso da Terrametrics so bre Measurement Systems for Control of Construction and Mining, Denver, mimeogr., $37 \mathrm{pp}$.

Piteau, D. R. ( 1970 ) - "Geological Factors Significant to the Stability of Slopes Cut in Rock ", 'imp. sôbre Planning Open Pit Mines, Joanesburgo, p. 33-53. 
B. 8

Potyondy, J. G. ( 1961 ) - " Skin Frictino between Cohesive Granular Soils and Construction Matexials, "Geotechnique, Vol 11, No. 4 , p. 339-353.

Rengers, N. ( 1970 ) - " Influence of Surface Roughness on the Friction

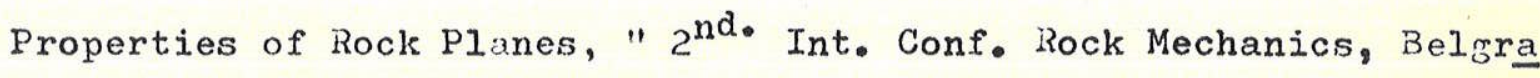
do, Vol. 1., p. 1-31.

Ripley, C. F., e K. L. Leee (1961) - "Sliding friction tests on sedimentary rock specimens ", Prans. $7^{\text {th }}$ Int. Congr. on Large Dams, Edinburg, Vol. 4, p. 657-671.

Robertson, A. M. ( 1970 ) - " The Interpretation of Geological Factors For Use in Sllope Theory ", Eroc. Symp., Planning Open Pit Mines, Joanesburgo, p. 55-71

Rocha, M. ( 1970 ) - " Mecânica das Rochas ", Caps. 1 a 4, Lab. Nac. Eng. Civ•, Lisboa, 2 Vols.

Roscoe, K.H., R.H. Basset e E.R.I. Cole ( 1967 ) - "Principal Axes Observed During Simple Shear of a Sand ", Proc. Geotech. Conf. Whear Strongth Properties of Natural Soils and Rock, Oslo, Vol. I, p. $231-237$.

Ruiz, M.D., e F.P. Camargo ( 1966 ) - " A large-soale field test on rock ", Proc. Ist. Int. Congx. Rock Mechamics, Lisboa, Vol. I, p. 257-261.

Ruiz, M.D. F.D. Camargo, N.F. Midea, e C.M. Nieble ( 1968 ) - "Some Considerations Regarding the Shear Strength of Rock Masses", Int. Symp. Rock Mechanics, Madri, p. 1.59-169.

Ruiz, M•D., C.M. Nieble, e F.C. Tarran ( 1969 ) - " Distribuição de tensões em Linsaios de Cisalhamento Usualmente Utilizados em "ecânica das Rochas $1^{a}$ Etapa: Meios Elásticos, Isotrópicos, Contínuos", - 
B.9

Anais $2^{a}$ Sem. Paul. Geol. Apl., Apga, S. Paulo, vol. 2, p. 507- / 550.

Salas, J. A. e S.R. Uriel ( 1964 ) - "Some recent rock mechanics testing in Spain ", Proc. 8th Int. Congx. on Large Dams, Edinburg, V. I, p. 998-1002.

Schmertmann, J. H. ( 1960 ) - " An experimental study of the development of cohesion e friction with axial strain in saturated cohesive soils ", Amer. Soc. Civil Engr., Research Conf. on Shear Strength of Cohesive Soils, Univ. of Colorado, p. 343-694.

Schultze, E. e A. Horn ( 1967 ) - "The Base Friction for Horizontally loaded footings in Sand and Gravel ", Geotechnique, Vol. 17, No.4, p. 329-347.

Schultze, E. ( 1957 ) - " Large scale shear tests ", Proc. 4th Int.Conf. Soil Mechanics e Foundation Engr., Londres, p. 193-199.

Serafim, J. L., e J.J.B. Lopes ( 1961 ) - "In-situ shear tests e triaxial tests of foundation rocks of concrete dams, "Proc. 5th Int. Conf. soil Mechanics and Foundation Lingr., Vol. 1. p. 533 539.

Simons, N. E. ( 1960 )" The effect of overconsolidation on the shear strength characteristics of an undisturbed Oslo Clay", Amer. Soc. Civil Ingr., Research Conf, on Shear Strength of Cohesive Soils, Univ. of Colorado, p. 747-763

Sinclair, S. R., e i. W. Brooker (1967)-"The shear strength of Edmonton Shale", Proc. Geotch. Conf. on Shear Strength Properties of Natural Soils and Rock, Oslo, Vol. 1, p. 295-299

Skempton, A. W. (1964)-Jong-term stability of clay slopes"(4th Rankine Lecture) Geotecnique, Vol.14, No.2, p. 77-101. 
Skempton, A. e D. J. Petley (1967)-"The strength along structural dis continuities in stiff clays, Proc.Geotech. Conf. on Shear Strength Properties of Natural Soils and Rock, Oslo, Vol. 2, p. 29-46.

Skempton, A. W. (1966) - "Some observations on Tectonic Shear Zones" Proc. $1^{\text {st }}$ Int. Congr. Rock Mechanics, Lisboa, Vol. 1 p. 329-335.

Spears, D. A. e R. K. Taylor ( 1972 ) - " The Influence of Weathering on the Composition and Engineering Properties of "In-situ " Coal Measures Rocks ", Int. Jour. Rock Mech. and Min.Sci,, Vol. 9, No. 6, Pergamon Press, Ing.

Stimpson, B. e G. Walton (1970) - " Clay Mylonites in English Coal Measures. Their Significance in Opencast Slope Stability ", $1^{\text {st }}$ Int. Congr. Int. Ass. Eng. Geol, Paris, Vol. 2, p. 1388-1393.

Taylor, D. W. (1960) - "Fundamentals of Soil Mechanics ", 6a ed., John Wiley and Sons, Inc. New York, $700 \mathrm{pp}$.

¿erzaghi, K. (1925)-"Erdbau Hechanik auf Bodenphysekalisher (“xundlage", F. Deutecke, Vienna.

Terzaghi, K. (1938)-"Caulomb's equation for the shear strength of cohesive soils", em From Theory to Practice in Soil Mechanics ( trad. ao ingles por L. Bjerrum), John Wiley and sons, p. 174 -180 .

Thorfinnson, S. T. (1954) - " A Làrge Scale Field Shear Test on a Bentonite Seam ", Proc. Am. Soc. Civ. Ing., Vol. 80, Sep. 549, $27 \mathrm{pp}$.

Trollope, D. H., e E. T. Brown (1966)-"Effective stress of failure of rock masses", Proc. $1^{\text {st }}$ Int. Congr. Rock Nechanics, Lisboa, Vol.I, p. 515-520.

Trollope, D. H. (1967) - Discussão, Geotechnical Conference ou Shear 


\section{B.11}

Strength Properties of Natural Soils and Rock, Oslo, Vol. 2, p. $178-180$.

Tulinov, Ro e I. Molokov (1971) - " Role of Joint Filling Material in Shear Strength of Rocks ", Int. Symp. Rock Kech., Rock Fracture, Nancy, Vol. 2, $13 \mathrm{pp}$.

Uff, J. F., e J. K. T. L. Nash (1967)-"Anisotropy of shale due to folding", Proc. Geotechnical Conf. on Shear Strength of Natural Soils and Rock, Oslo, Vol. 2, p. 289-294

Uriel, S. (1968)-"In-Situ direct shear tests on limestone, joints of irregular surfaces filled with clay material", Int. Symp. on Rock Mechanics, Madri, $15 \mathrm{pp}$.

Withers, J. H. (1964)-"Sliding resistance along discontinuities in rock masses", Ph. D. Thesis, Univ. of Illinois, Urbana, $124 \mathrm{pp}$. 